\title{
Environmental controls on coccolithophore blooms in the Southwest Pacific Ocean during Marine Isotope Stages 5e (125 ka) and 7a (210 ka)
}

\section{Bella Jane Duncan}

\author{
A thesis submitted to \\ Victoria University of Wellington \\ In partial fulfilment of the requirements for the degree of \\ Master of Science \\ In \\ Geology
}

School of Geography, Environment and Earth Sciences

Victoria University of Wellington 


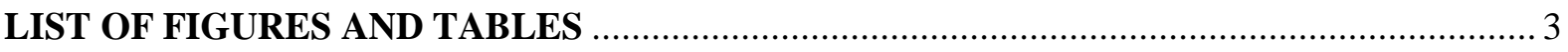

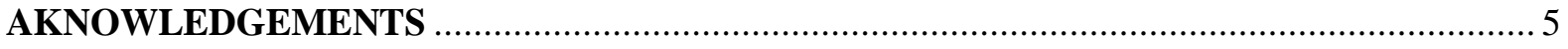

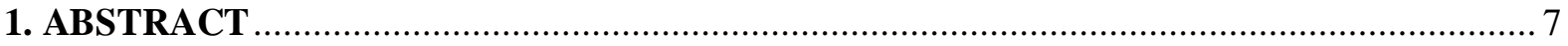

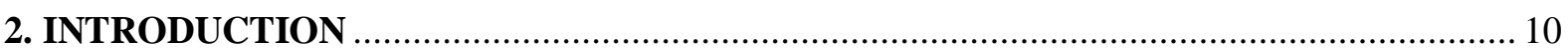

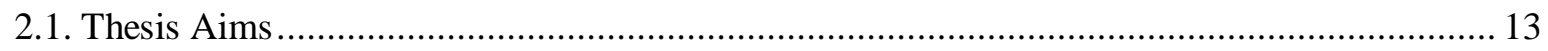

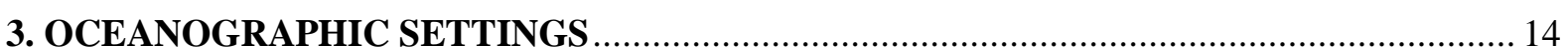

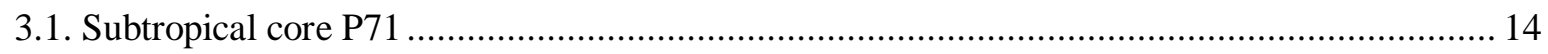

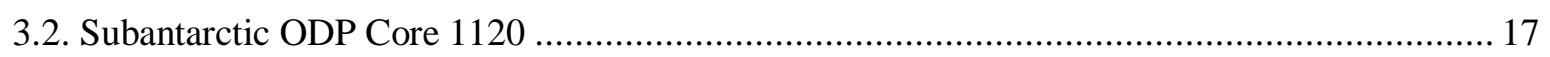

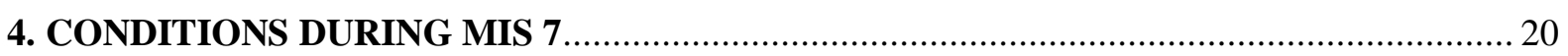

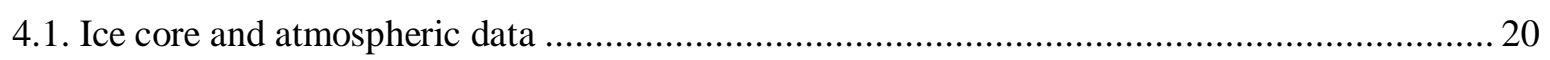

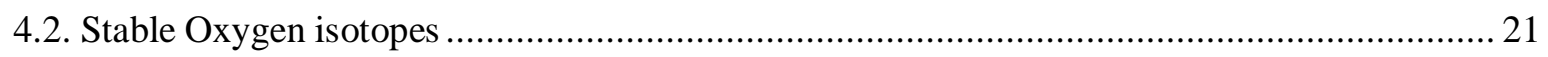

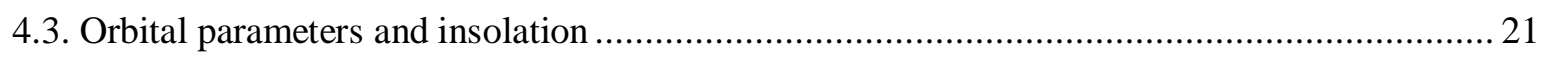

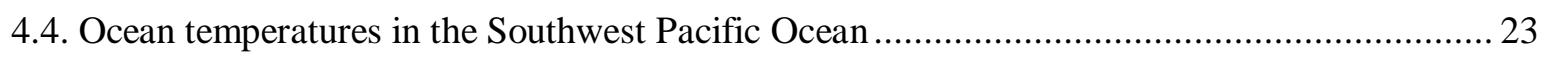

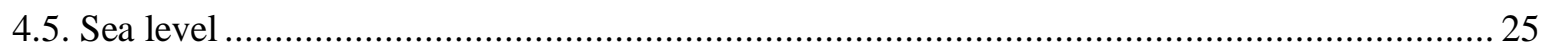

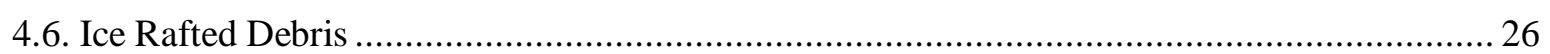

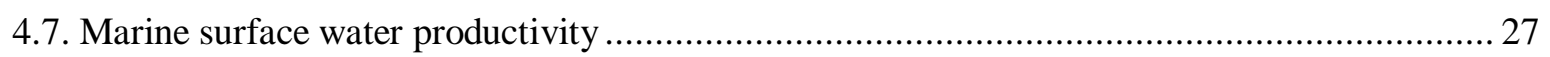

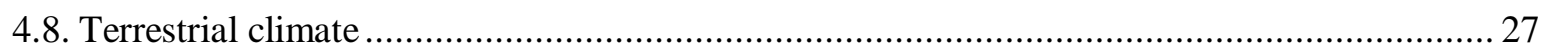

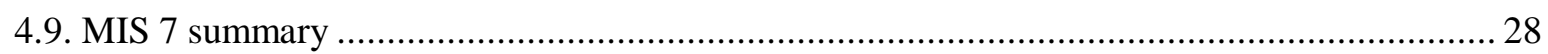

5. ECOLOGY OF FORAMINIFERA AND COCCOLITHOPHORES …................................... 30

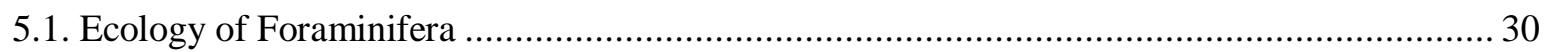

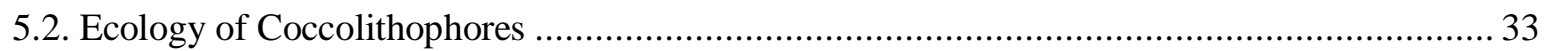

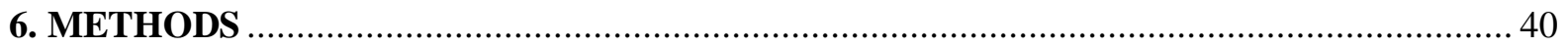

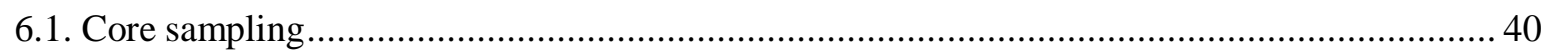

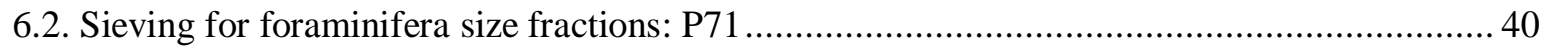

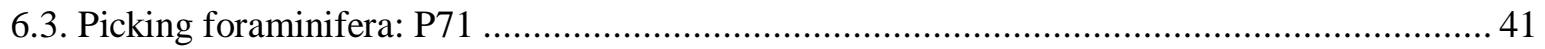

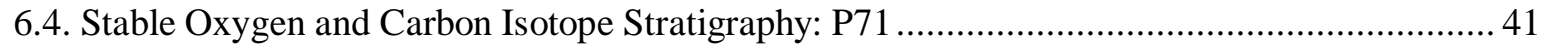

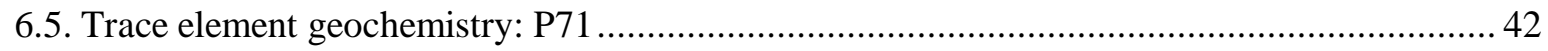

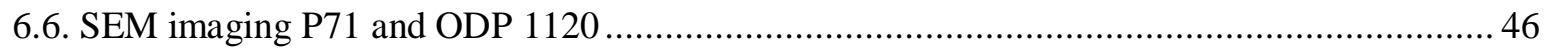

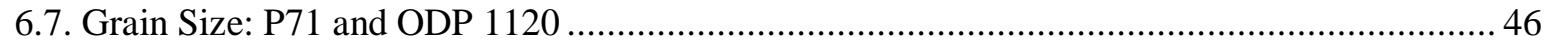

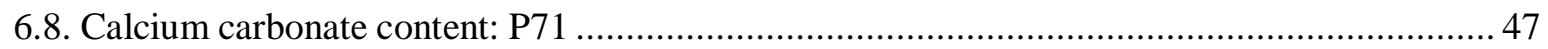

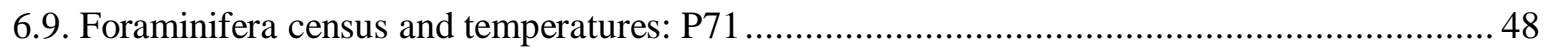

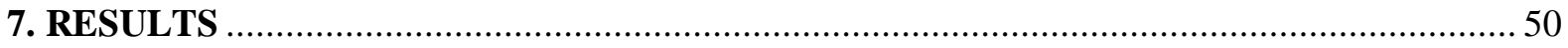




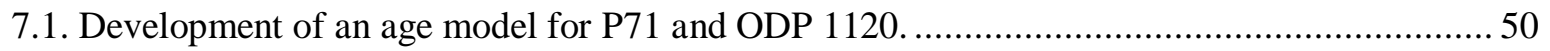

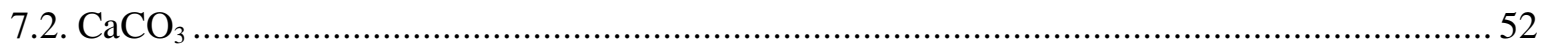

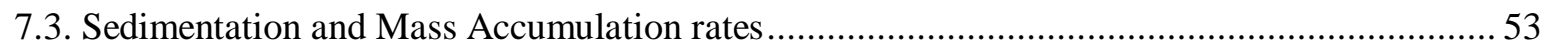

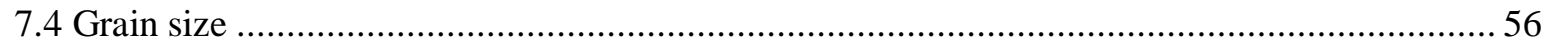

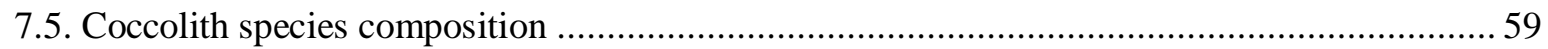

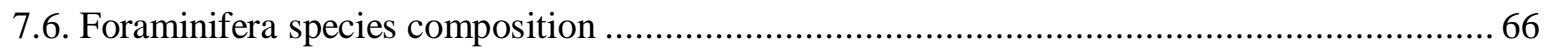

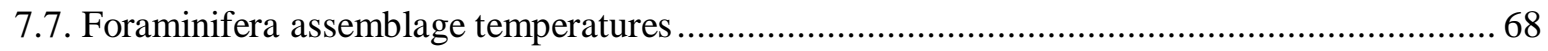

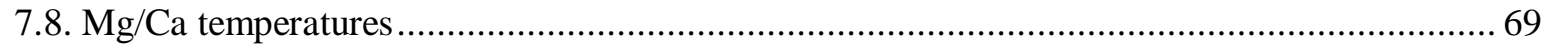

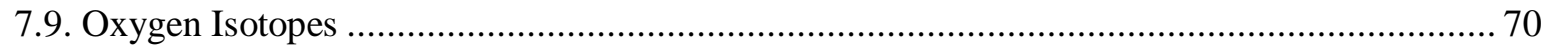

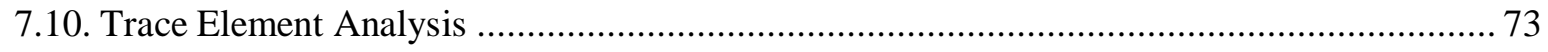

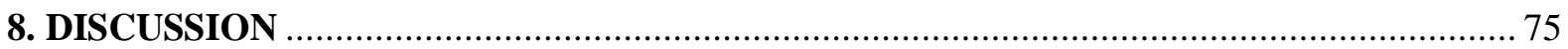

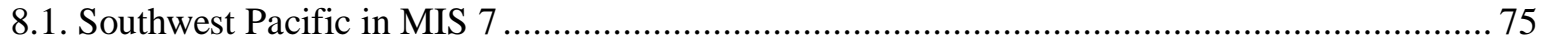

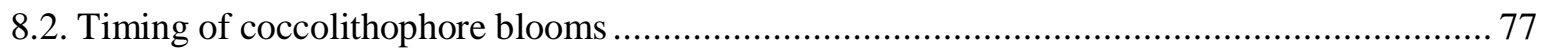

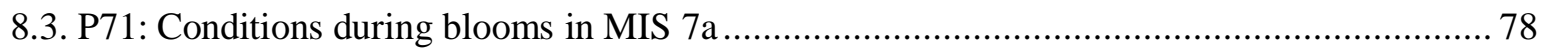

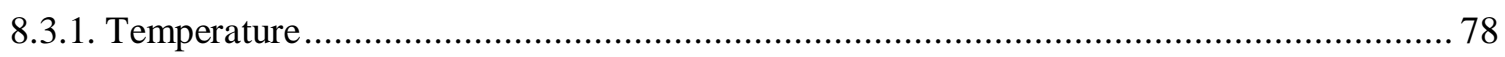

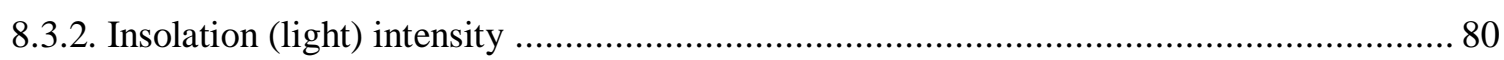

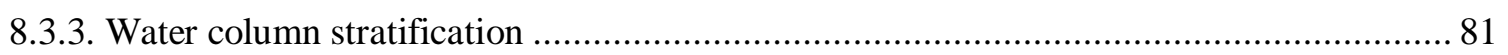

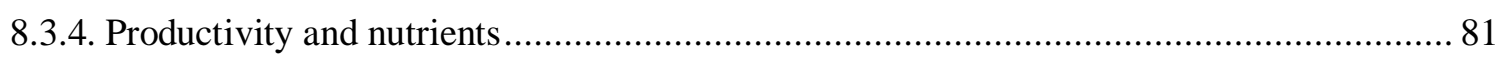

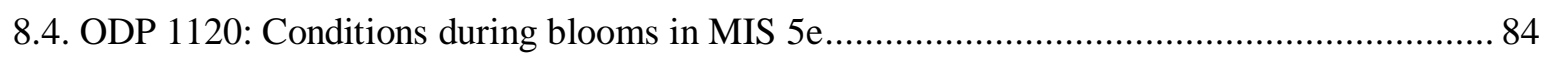

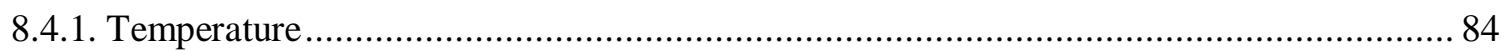

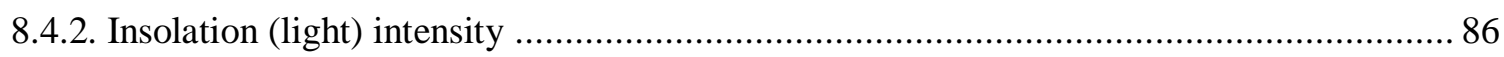

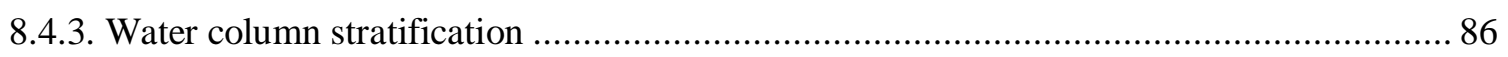

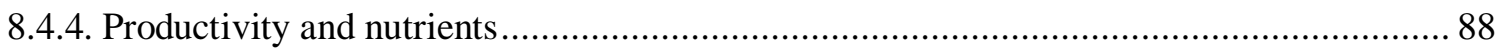

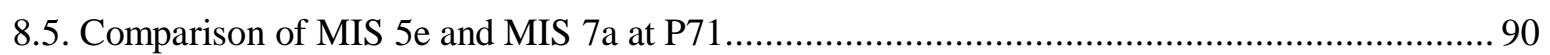

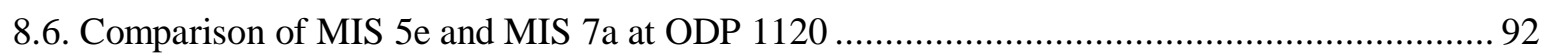

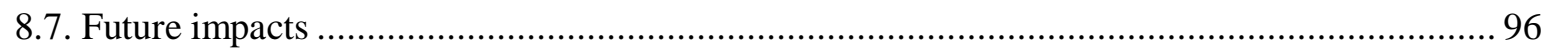

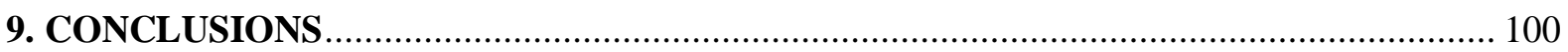

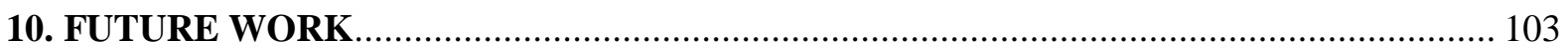

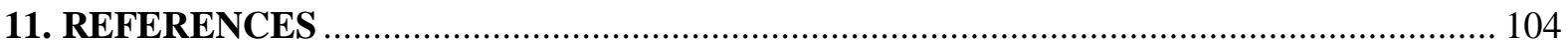

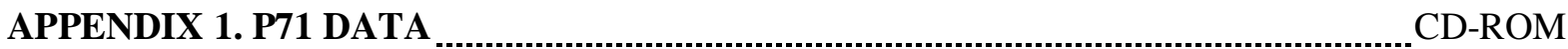

APPENDIX 2. ODP 1120 DATA

APPENDIX 3. TRACE ELEMENT DATA _................................................. 
Figure 2.1: Phytoplankton blooms over the Chatham Rise 11

Figure 3.1: Oceanographic setting 15

Figure 3.2: Chlorophyll concentrations around New Zealand

Figure 4.1: LR benthic oxygen isotope stack 20

Figure 4.2: Orbital parameters for the past $280 \mathrm{kyr}$ 22

Figure 4.3: Sea surface temperatures during MIS 7a and 7c 24

Figure 5.1: Foraminifera species used in this study 33

Figure 5.2: Dominant coccolithophore species in this study 34

Figure 6.1: Foraminifera mounted to adhesive paper for trace element analysis 43

Figure 6.2: Trace element profiles of foraminifera 44

Figure 6.3: $\mathrm{CaCO}_{3}$ vacuum line 47

Figure 6.4: Random Forest Model accuracy 49

Figure 7.1: Age models for P71 and ODP 1120 51

Figure 7.2: $\mathrm{CaCO}_{3}$ percentages for P71 and ODP 1120 52

Figure 7.3: Depth vs. time, sedimentation rate and $\mathrm{MAR} \mathrm{CaCO}_{3}$ for $\mathrm{P} 71$ 54

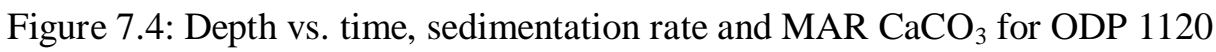
55

Figure 7.5: MAR $<20 \mu \mathrm{m}$ sediment for P71 and ODP 1120. 56

Figure 7.6: Grain size distribution for P71 and ODP 1120

Figure 7.7: Percentage of $<20 \mu \mathrm{m}$ sediment of P71 and ODP 1120 59

Figure 7.8: SEM images and grain size distribution for MIS 1 in P71 60

Figure 7.9: SEM images and grain size distribution for MIS 2 in P71 61

Figure 7.10: SEM images and grain size distribution for MIS 7a in P71 62

Figure 7.11: SEM images and grain size distribution for MIS 1 in ODP 1120 63

Figure 7.12: SEM images and grain size distribution for MIS 5e in ODP 1120 64

Figure 7.13: SEM images and grain size distribution for MIS 7a in ODP 1120 65

Table 7.1: Environmental zones for foraminifera species 67

Figure 7.14: Foraminifera assemblage percentages 68 
Figure 7.15: Foraminifera assemblage temperatures 69

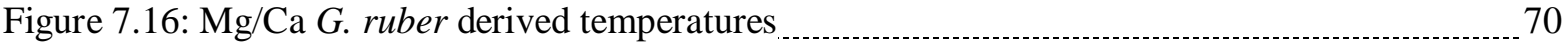

Figure 7.17: $\delta^{18} \mathrm{O}$ for ODP 1120

Figure 7.18: $\delta^{18} \mathrm{O}$ for P71

Figure 7.19: $\delta^{18} \mathrm{O}$ derived water column stratification $\quad 72$

Figure 7.20: $\mathrm{Zn} / \mathrm{Ca}$ and $\mathrm{Mn} / \mathrm{Ca}$ G. ruber

Figure 8.1: Summary of key data sets for P71

Figure 8.2: Upper water column conditions during MIS 7a at P71

Figure 8.3: Summary of key data sets for ODP $1120 \ldots \ldots$

Figure 8.4: Upper water column conditions during MIS 5e at ODP 1120

Figure 8.5: Upper water column conditions during MIS 5e at P71

Figure 8.6: Upper water column conditions during MIS 7a at ODP $1120 \ldots \ldots$ 


\section{AKNOWLEDGEMENTS}

Thanks must first go to my indispensable supervisors, Lionel Carter, Gavin Dunbar and Helen Bostock. Lionel's enthusiasm and knowledge has been fantastic, and has helped me remain excited and confident about my project. Gavin has been especially helpful with lab work, and always willing to talk through ideas. I have Helen to thank for giving me the opportunity to go to the Southern Ocean, and always being forthcoming with advice and suggestions. You have been amazing supervisors!

There have been many other people whose help has been integral to completing my thesis. I'm extremely grateful to ANZICE, who provided funding for this project. I am also grateful for receiving a Victoria Graduate Award and the Helen Stewart Royle Scholarship. Helen Neil produced my isotope data and allowed me to use the ODP 1120 data, and has been helpful with interpretation. Marc-Alban Millet helped me to analyse my $\mathrm{Mg} / \mathrm{Ca}$ foraminifera data. Bruce Hayward and Ashwaq Sabaa at Geomarine Ltd provided my foraminifera assemblage data. George Scott and Guiseppe Cortese provided the foraminifera assemblage temperatures. Denise Kulhanek assisted with coccolithophore identification and ecology. Euan Smith has been a statistical whizz, working out errors for my $\mathrm{Mg} / \mathrm{Ca}$ data. Thanks to my office mates for cups of tea and thoughtful chats, especially Julene Marr for your enthusiasm and help with foraminifera ecology and oceanographic interpretation. Thanks to Annette Bolton and Kylie Christiansen for useful foraminifera discussions. The Antarctic Research Centre has been a fantastic place to work in, thanks for creating such a positive atmosphere and always encouraging and including all of us students. I'm also grateful for the tutoring work I've received during my Masters, the field trips in particular have been highlights of being a postgraduate and it has been great to get to know the undergraduates. 
My lovely ladies, Jaime, Liz, Nicole, Tessa and Tracey, you've kept me in just the right stage of madness, and been there with love, laughter and cider. My geological family have shared the ups and downs of life, uni and beer pong over the last five and half years, especially Gemma, Cara, Kylie, Georgia, Chris, Sanne, Katie, Danny, Denise, Boots, Matt, Timmy, Ash, Brook, Ben and many others. Thank you for your friendship and so many awesome memories.

Thank you Max for your love, calmness, and gratefully eating all the food I cook to de-stress! My family have been fantastic at encouraging me and being interested in what I do. Mum, Dad and Hamish, you've always been my biggest supporters and encouragers. You set the foundations for the person I've grown up to be, and have helped me every step of the way. Thank you for telling me that you would unconditionally love and support me in which ever dreams I chose to follow. 


\section{ABSTRACT}

Coccolithophores play a key role in the ocean carbon cycle, regulating the uptake and release of $\mathrm{CO}_{2}$. Satellite observations over the past few decades show ocean change in a warming world is accompanied by changes in the latitudinal distribution of coccolithophore blooms. Despite their importance in the carbon cycle, knowledge of the causes of coccolithophore blooms, and how they may respond to future climate change is limited. In this study evidence from marine sedimentary cores is used to derive longer, more complete records of past coccolithophore productivity, and the factors that potentially caused enhanced coccolithophore productivity in previous interglacials.

Carbonate-rich marine cores; subtropical P71 from north of New Zealand (33 51.3'S, $174^{\circ} 41.6^{\prime} \mathrm{E}$ ) and subantarctic Ocean Drilling Project (ODP) 1120 from the Campbell Plateau $\left(50^{\circ} 3.803^{\prime} \mathrm{S}, 173^{\circ} 22.300^{\prime} \mathrm{E}\right)$ show abrupt changes between foraminiferal-rich sediments during glacials to coccolith-rich sediments during interglacials. Both cores encompass the last two complete interglacial cycles, Marine Isotope Stage (MIS) 5 (71-130ka) and MIS 7 (191243ka). While MIS 5 has been well-studied in the Southwest Pacific Ocean, research on MIS 7 is limited. From the literature, and data from this study, new insights are presented into the climatic and oceanographic conditions during MIS 7. Sea surface temperatures in the subtropical Tasman Inflow were comparable to present during MIS 7a (191-222ka), but were cooler in MIS 7c (235-243ka), implying a change in flow regime potentially related to the dynamics of the South Pacific Gyre. During MIS 7a and 7c the temperature gradient across the Subtropical Front (STF), which separates subtropical and subantarctic waters, was greater than present on the Chatham Rise, at $>2^{\circ} \mathrm{C}$ per $1^{\circ}$ latitude. In the Tasman Sea, the STF moved northwards by $\sim 2^{\circ}$ latitude. 
This thesis employs grain size data and scanning electron microscope images to show that significant coccolithophore blooms occurred during MIS 7a at subtropical core P71, but not during interglacial peak MIS 5e (117-130ka), whilst the reverse is true at subantarctic core ODP 1120. A range of paleo-environmental proxies are used to determine the potential conditions that caused these coccolithophore blooms. This includes mass accumulation rates of $\mathrm{CaCO}_{3}$ and $\%$ of $<20 \mu \mathrm{m}$ grain size that texturally identifies coccoliths, to determine relative rates of coccolithophore productivity. Oxygen isotopes $\left(\delta^{18} \mathrm{O}\right)$ of multiple planktic and benthic foraminifera provide age models, with the former also helping to identify upper water column stratification. $\mathrm{Mg} / \mathrm{Ca}$ ratios in planktic foraminifera, Globigerinoides ruber, and Random Forest modelling of planktic foraminifera assemblages have been used to derive paleo-temperature estimates. These methods, coupled with trace element data from G. ruber as a productivity proxy, foraminifera assemblages, data on solar insolation and scanning electron microscope images, collectively determine the oceanic conditions at the time of coccolithophore blooms at each core site. The results suggest that no one factor was responsible for blooming, rather it was the combination, and interactions between different environmental processes, that were important.

At P71, key factors for bloom formation in MIS 7a were high insolation, thermal stratification of the uppermost ocean, and well-mixed source waters from the Tasman Inflow. At ODP 1120, blooms in MIS 5e resulted from decreased windiness, warmer sea surface temperatures and reduced oceanic circulation over the Campbell Plateau, resulting in marked thermal stratification. It is likely that coccolithophore blooms further enhanced stratification at each core site, and restricted productivity further down the water column. At P71, modern oceanic trends suggest that conditions that caused blooms during MIS 7a will not be met in the near future, and blooming is unlikely to increase at this core site. At ODP 1120, modern 
trends are less clear, but future conditions are projected to be comparable to MIS 5e, suggesting that coccolithophore blooming may increase in the future in subantarctic waters. 


\section{INTRODUCTION}

A key question facing environmental science is "How will the ocean environment respond to the present phase of changing climate?" This question is especially relevant to marine phytoplankton as they form the base of the marine food chain and are a regulator of the oceans' uptake and release of carbon dioxide (Legendre, 1990, Iglesias-Rodríguez et al., 2002, Baumann et al., 2004, Rost and Riebesell, 2004). Thus they play a key role in how the ocean interacts with the atmosphere (Legendre, 1990, Iglesias-Rodríguez et al., 2002, Baumann et al., 2004, Rost and Riebesell, 2004). Satellite observations show widespread blooms of phytoplankton including events off New Zealand (Fig. 2.1) (MODIS, http://modis.gsfc.nasa.gov/, SeaWiFS, http://oceancolor.gsfc.nasa.gov/SeaWiFS/). This satellite imagery shows that the global distribution of blooms has changed over the last 20-30 years, advancing into higher latitudes, whilst becoming scarcer closer to the equator (IglesiasRodríguez et al., 2002, Smyth et al., 2004). Local blooms off New Zealand targeted for their milky white colouration, have been sampled and found to contain predominantly coccolithophores (H. Chang and C. Law, NIWA, pers. comm.). Coccolithophores are calcifying phytoplankton inhabiting the sunlit layer of the ocean, and play an important role in the marine carbon system as they are the most productive calcifying organism on Earth (Rost and Riebesell, 2004, Boeckel et al., 2006).

Coccolithophores first appeared in the late Triassic, and since the mid-Cretaceous the combination of coccolithophores and planktic foraminifera has been largely responsible for creating and maintaining the vertical gradient of alkalinity in the ocean (Rost and Riebesell, 2004). They also have an impact on climate, since the ratio of inorganic calcite to organic carbon in the surface ocean is an important component of the carbon cycle, linking the oceans to the atmosphere (Rost and Riebesell, 2004, Zondervan, 2007). Coccolithophores contribute 
to the organic carbon pump by the drawdown of $\mathrm{CO}_{2}$ during photosynthesis, and subsequent transferral of $\mathrm{CO}_{2}$ to the deep ocean upon death, although they also play a role in the carbonate counter pump, by releasing $\mathrm{CO}_{2}$ during calcification (Baumann, 2004, Rost and Riebesell, 2004, Zondervan, 2007). Coccolithophores therefore can be a smaller sink for $\mathrm{CO}_{2}$ when compared to non-calcifying phytoplankton, and in fact coccolithophore blooms can occasionally become a source for $\mathrm{CO}_{2}$ (Rost and Riebesell, 2004). Coccolithophores are sensitive to changes in the photic zone, including light levels, nutrient availability, temperature and stratification (Tyrrell and Merico, 2004, Zondervan, 2007). Despite their importance, we currently do not fully know the causes of coccolithophore blooms or how they will respond to projected environmental change (Rost and Riebesell, 2004, Zondervan, 2007).

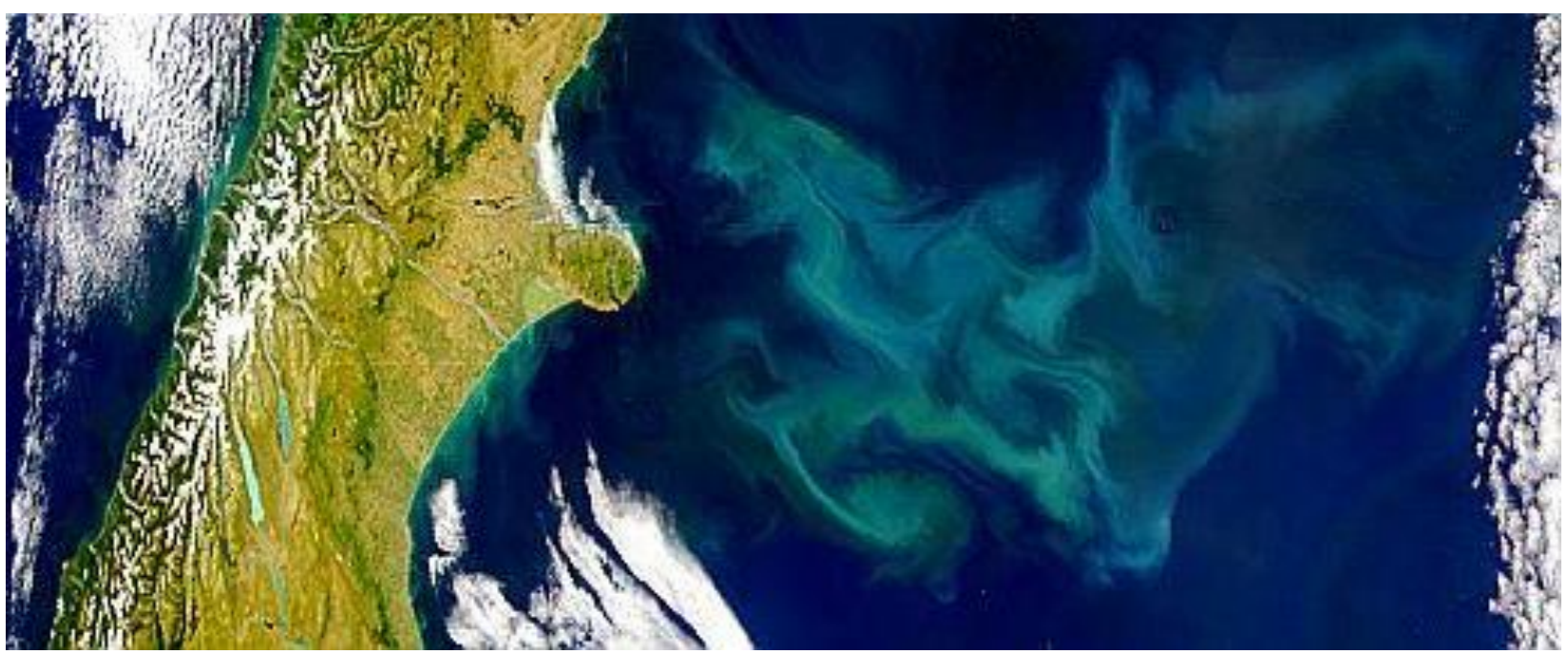

Figure 2.1: Phytoplankton blooms over the Chatham Rise 1st February 1999. Image sourced from SeaWiFS http://oceancolor.gsfc.nasa.gov/cgi/image_archive.cgi?c=CHLOROPHYLL.

While satellite observations only span a few decades, a longer, more representative record may be derived from sediments encompassing past Quaternary interglacials. Descriptions of deep-sea sediment cores from the New Zealand region have previously noted a distinct change in carbonate skeletal composition over time: glacial periods are typically represented 
by foraminifera-rich sediment, whereas interglacial periods are times of coccolithophore-rich deposition (Carter et al., 1999), although reasons for these alterations have not been investigated. Elsewhere, previous work has focused on coccolithophore species distribution or the interplay between diatoms and coccolithophores over glacial/interglacial cycles (Okada and Wells, 1997, Flores et al., 2003, Okazaki et al, 2005, Incarbona et al., 2010, SaavedraPellitero et al., 2011, Khim et al., 2012). Few studies have examined reasons for the often significant changes in the relative proportions of coccolithophores and foraminifera in marine sediments, and those that do have mainly examined modern-Holocene samples (Baumann et al., 2004, Frenz et al., 2005, Broecker and Clark, 2009). In New Zealand, research into offshore coccoliths in modern/Quaternary sediments is limited, and has focused on the latitudinal distribution of different assemblages (Burns, 1972). Therefore, this study is the first work to investigate the changing proportions of coccolithophores and foraminifera in marine cores in the Quaternary, and the environmental conditions that led to these changes. In that context, this study will undertake a paleo-environmental reconstruction of prominent phases of coccolithophore blooms over the last two complete glacial/interglacial cycles at a subtropical and a subantarctic marine core site in the Southwest Pacific Ocean. The term 'bloom' in this study refers to periods of time when there was increased coccolithophore productivity, interpreted as times when seasonal coccolithophore blooms were more frequent and/or enhanced.

Core sites used are subtropical P71 from north of New Zealand (33 ${ }^{\circ} 51.3^{\prime} \mathrm{S}, 174^{\circ} 41.6^{\prime} \mathrm{E}$, 1919m water depth) and subantarctic Ocean Drilling Program (ODP) 1120 from the Campbell Plateau (50³.803'S, $173^{\circ} 22.300^{\prime} \mathrm{E}, 543 \mathrm{~m}$ water depth). Marine cores from subtropical waters (STW) and subantarctic waters (SAW) can provide a comparison between the productivity of coccolithophores in these two water masses over time. Initial visual core description identified one prominent zone of greatly enhanced coccolith abundance in each 
core: Marine Isotope Stage (MIS) 7a (191-222 ka) in P71 and MIS 5e (117-130 ka) in ODP 1120. Other research has concentrated on MIS 5e as an analogue for future climate change, with sea levels during this period inferred to be $\sim 5-6 \mathrm{~m}$ higher than present and global temperatures $\sim 2-4^{\circ} \mathrm{C}$ warmer (Petit et al., 1999, Pelejero et al., 2003, Jouzel et al., 2007, Rohling et al., 2008, Kopp et al., 2009). In contrast, little work has focussed on the environmental conditions during MIS 7 (191-243ka), during which temperatures and sea levels were likely comparable or lower than today, and lower than MIS 5e (Petit et al., 1999, Jouzel et al., 2007, Rohling et al., 2009).

\subsection{Thesis Aims}

The primary objectives of this thesis are:

- To reconstruct the environmental conditions associated with high coccolithophore productivity in the Late Quaternary in the Southwest Pacific Ocean under subtropical and subantarctic ocean conditions; and

-To determine the causal factors for significant coccolithophore productivity changes in MIS 7a and MIS 5e, and use this knowledge to assess the likely future productivity changes in the oceans surrounding New Zealand.

The secondary aim of this thesis is:

-To develop a method for quantifying changes in coccolithophore abundance over time from sediment grain size. 


\section{OCEANOGRAPHIC SETTINGS}

This study uses core P71 from a subtropical site, and core ODP 1120 from a subantarctic site. Section 3 describes the location and oceanographic setting for each core site.

\subsection{Subtropical core P71}

Subtropical Core P71 is a gravity core that was collected by NIWA in 1977 from 1919m water depth. The core site is located at $33^{\circ} 51.3^{\prime} \mathrm{S}, 174^{\circ} 41.6^{\prime} \mathrm{E}$ (Fig. 3.1).

P71 is located within the boundary of the southeastward-flowing East Auckland Current (EAUC), a branch of the Tasman Front (Fig. 3.1) (Stanton, 1973). The Tasman Front separates from the East Australian Current (EAC) between latitude $31-33^{\circ} \mathrm{S}$ on the eastern Australian seaboard, and meanders across the Tasman Sea before attaching to the New Zealand continental margin to form the EAUC (Sutton and Roemmich, 2001, Ridgway and Dunn, 2003, Orpin et al., 2008). The EAUC has a mean transport of 11.2 Sverdrups (Sv) (Ridgway and Dunn, 2003). The core site is on the edge of the North Cape Eddy (NCE), an anticyclonic, permanent warm core eddy that re-circulates approximately $50 \%$ of the EAUC (Stanton et al., 1997, Sutton and Roemmich, 2001).

The surface water above site $\mathrm{P} 71$ is $\mathrm{STW}$, which is warm $\left(>15^{\circ} \mathrm{C}\right)$, highly saline $(>34.7 \mathrm{psu})$ and seasonally macro-nutrient depleted (Heath 1985, Boyd et al., 1999). Antarctic Intermediate Water (AAIW) occurs at depths of $\sim 600-1450 \mathrm{~m}$ and is characterised by temperatures of $3-7^{\circ} \mathrm{C}$ and salinities of 34.3-34.5psu (Heath, 1985, McCave and Carter, 1997, Stanton, 2002). Here, AAIW is sourced from the west and flows from the Coral and Tasman seas under the South Pacific Gyre (Stanton, 2002). The deepest water mass at this location, at depths of $1450 \mathrm{~m}$ to the seafloor, is upper Circumpolar Deep Water (uCPDW) with temperatures ranging from $1.8-3^{\circ} \mathrm{C}$ and salinities of 34.5-34.7psu (McCave and Carter, 1997). 


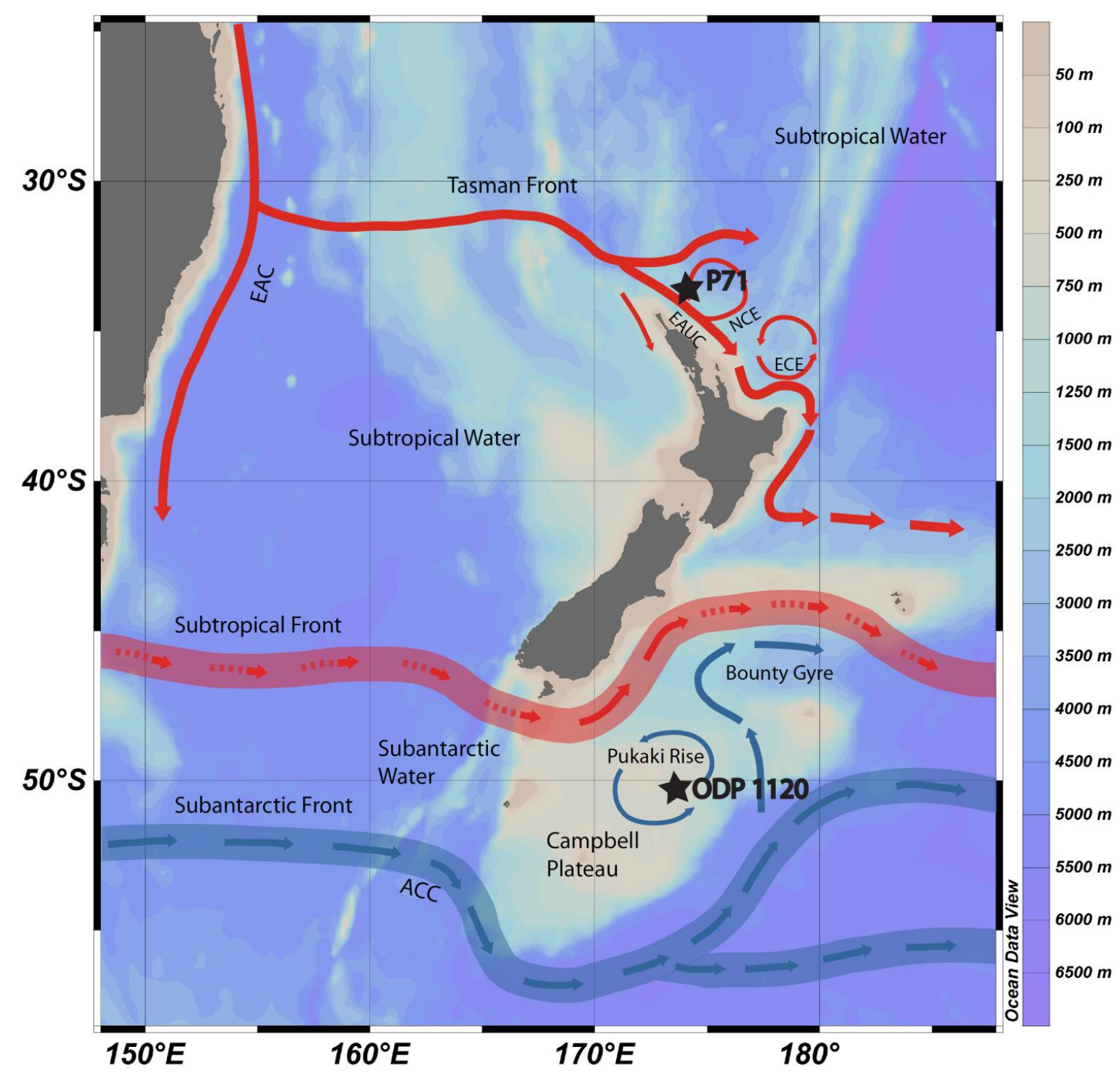

Figure 3.1: Core site location of P71 and ODP 1120 with main surface currents and surface water masses modified from Orpin et al. (2008). EAC= East Australian Current. EAUC= East Auckland Current. NCE = North Cape Eddy. ECE = East Cape Eddy. ACC = Antarctic Circumpolar Current. Dashed arrows on STF represent weaker flow to full arrows.

The modern mean annual sea surface temperature (SST) at P71 is $19.34^{\circ} \mathrm{C}(\mathrm{CARS}, 2009)$, and has a seasonal variation of approximately $5^{\circ} \mathrm{C}$ (Sutton and Roemmich, 2001, CARS, http://www.marine.csiro.au/ dunn/cars2009/). The temperature gradient is dependent on the depth of the mixed-layer and the seasonal thermocline (Sutton and Roemmich, 2001). The 
mixed-layer in summer occurs at $30 \mathrm{~m}$, deepening in winter to $>100 \mathrm{~m}$ depth (Sutton and Roemmich, 2001). Below this, there is a steady decrease in temperature with depth, remaining constant throughout the year (Sutton and Roemmich, 2001).

Productivity in STW is co-limited by nitrate availability and light (Murphy et al., 2001). Within STW cycles of spring and autumn chlorophyll blooms occur (Murphy et al., 2001). The spring bloom is particularly prominent. This is a result of the deep mixing layer in winter which pushes the pycnocline below the photic depth, enriching the photic zone in nutrients (Murphy et al., 2001). When wind stress decreases in spring and deep mixing ceases, stratified layers with weak mixing emerge in the upper water column (Chiswell, 2011). The spring bloom initiates in these surface layers, and continues as the seasonal thermocline shallows in response to increasing spring light levels and lower wind stress (Chiswell, 2011). Winter and summer productivity is limited by light and nitrate, respectively, while autumn productivity is dependent on the balance between these two variables (Murphy et al., 2001). Southwest of the core site near the continental shelf, the EAUC shoals and colder, nutrientbearing waters upwell to near the surface, enhancing productivity (Roemmich and Sutton, 1998). Northeast of P71, Murphy et al. (2001) found that the centre of the anticyclonic NCE has low chlorophyll, while its boundaries are marked by enhanced production of chlorophyll. South of the core site, the East Cape Eddy is also an anti-cyclonic warm core eddy, with a spring phytoplankton bloom, potentially also related to deep winter mixing, which limits productivity and conserves nutrients until the water column stabilises in spring (Bradford et al., 1982). 


\subsection{Subantarctic ODP Core 1120}

ODP Core 1120 is a piston core collected during Leg 181 in 1998 from 543m water depth. The core site is located at $50^{\circ} 3.803^{\prime} \mathrm{S}, 173^{\circ} 22.300^{\prime} \mathrm{E}$ on the southeast margin of the Pukaki Rise, on Campbell Plateau (Carter et al., 1999) (Fig. 3.1)

The interior of Campbell Plateau has a weak anticyclonic gyre circulation, bound at the margins by the Subantarctic and Subtropical fronts (Morris et al., 2001, Bradford-Grieve at al., 2003, Neil et al., 2004) (Fig. 3.1). Geostrophic flow across the plateau is weak but persistent, with average speeds of less than $10 \mathrm{cms}^{-1}$ (Stanton and Morris, 2004). An inflow from the Antarctic Circumpolar Current (ACC) separates from the Subantarctic Front and passes through the Pukaki Saddle to contribute to the cyclonic Bounty Gyre (Morris et al., 2001). A much smaller anticyclonic circulation, mainly from flow over the Campbell Plateau, occurs around the Pukaki Rise (Morris et al., 2001).

The surface water at the ODP Site 1120 is SAW, which is cool (mean annual temperature range of $\left.8-15^{\circ} \mathrm{C}\right)$, macro-nutrient rich, micro-nutrient poor and less saline (34.5-34.7psu) than STW (Heath, 1985, Boyd et al., 1999, Morris et al., 2001). The sub-surface water is made up of Subantarctic Mode Water (SAMW), a component of AAIW sourced from deep mixing along the equatorward side of the Subantarctic Front (SAF) (Morris et al., 2001). SAMW is characterised by temperatures of approximately $7^{\circ} \mathrm{C}$, near-isothermal stratification and salinities of 34.35-34.4psu (Morris et al., 2001).

SSTs at the site vary from $8.5-9^{\circ} \mathrm{C}$ in summer and autumn, to $7.5-8^{\circ} \mathrm{C}$ in winter and spring, with a mean annual SST of $\sim 8.25^{\circ} \mathrm{C}$ (Morris et al., 2001). In spring to summer the thermocline and mixed layer shoal to $160 \mathrm{~m}$ and $<50 \mathrm{~m}$ deep, respectively (Morris et al., 2001). In autumn the seasonal thermocline extends down to $200 \mathrm{~m}$, while in winter it breaks 
down due to wind stirring and buoyancy loss, and the water column becomes well mixed (Morris et al., 2001).

Waters over Campbell Plateau are rich in the macronutrients nitrate and phosphate but depleted in micronutrients, most importantly iron. Thus productivity in SAW is co-limited by light and iron, and there is little intra-annual variability in chlorophyll production (Murphy et al., 2001). This limitation has resulted in low primary production and a tendency towards small forms of phytoplankton (Boyd et al., 1999, Bradford-Grieve et al., 2003). Murphy et al. (2001) used satellite imagery to estimate chlorophyll $a$ concentrations in SAW and found peaks in late summer and early autumn, with minimum productivity occurring in late winter. Smaller peaks in productivity also occurred in March and November, but varied from year to year, suggesting that conditions are not consistently favourable for productivity during these months. Northcote and Neil (2005) investigated sediment trap data from the Pukaki Rise and found a sharp peak in foraminifera productivity in mid-spring. King and Howard (2001) and Nodder and Northcote (2001) used sediment traps on a transect through the STF to estimate production peaks from the mass flux of particulates reaching the traps. Flux in SAW, just south of the STF, peaked in November (austral spring), with minor peaks occurring in September, February and March. A mooring on the northern flank of the Bounty Trough found flux peaks of particulate organic carbon and biogenic silica occurred in September (Nodder et al., 2005). However flux peaks at depth can not necessarily be interpreted as occurring at the same time as a productivity peak at the surface, due to temporal lags in the export of biomass to depth (Nodder et al., 2005). While productivity overall on the Campbell Plateau is low, phytoplankton blooms do occur at Pukaki Rise (Murphy et al., 2001, Boyd et al., 2004, Hayward et al., 2007) (Fig. 3.2). The causes of blooms at this location are debated but may be due to changes in the supply of iron to the site from upwelling, lateral transport of iron-bearing waters or from aeolian dust (e.g. Boyd et al., 2004). 


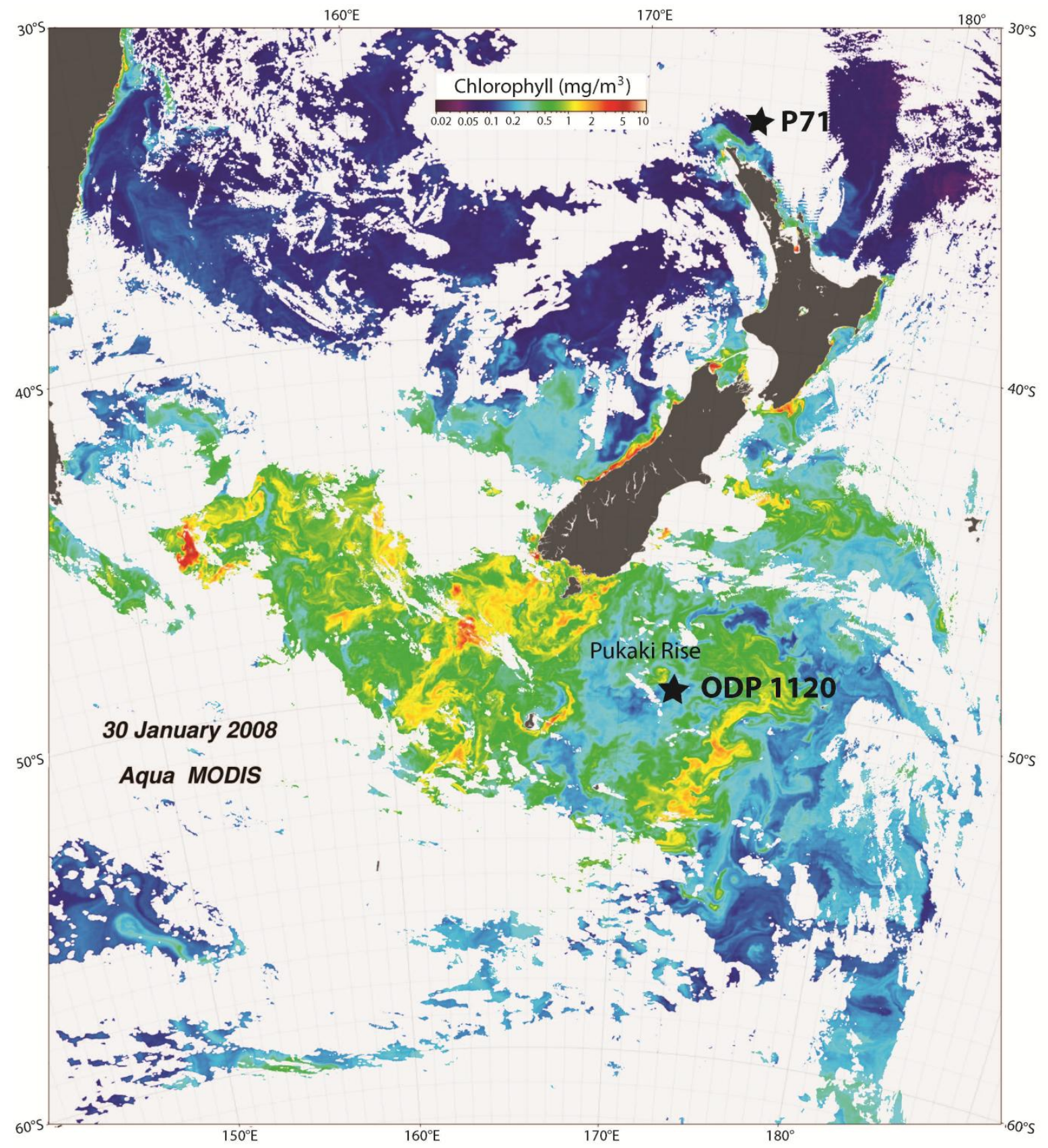

Figure 3.2. Chlorophyll concentrations on the 30th of January 2008 around New Zealand sourced from SeaWiFS

http://oceancolor.gsfc.nasa.gov/FEATURE/IMAGES/A2008030.NewZealandChlorophyll.png 


\section{CONDITIONS DURING MIS 7}

Marine Isotope Stage (MIS) 7 extends from 243 to 191 ka (Lisiecki and Raymo, 2005). It can be divided into interstadial 7c (235-243ka), stadial 7b (235-222ka) and interstadial 7a (222191ka) (Fig. 4.1).

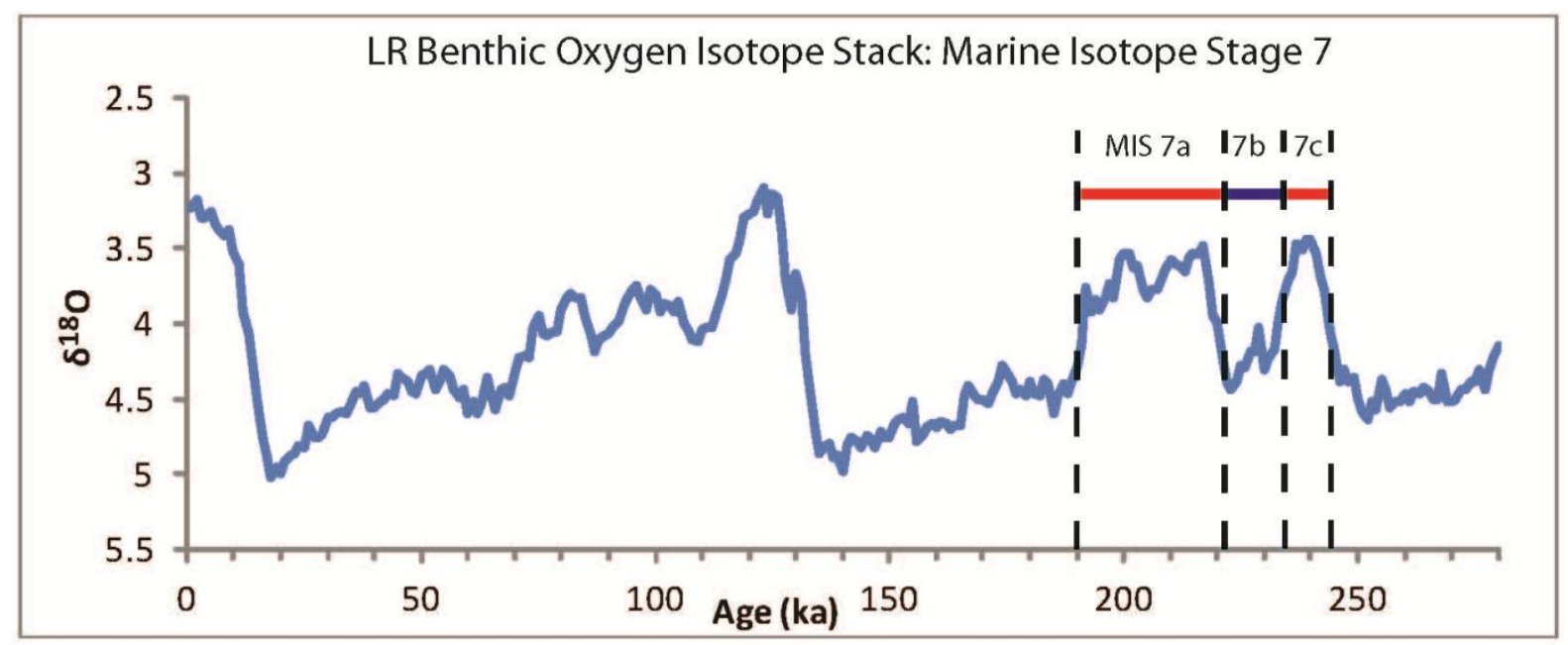

Figure 4.1: Lisiecki Raymo 04 Benthic Oxygen Isotope Stack (Lisiecki and Raymo, 2005)

showing division of MIS 7 into $7 a, b$ and $c$.

\subsection{Ice core and atmospheric data}

Carbon dioxide $\left(\mathrm{CO}_{2}\right)$ levels from MIS 7 have been recorded in the Vostok ice core (Petit et al., 1999). Although the EPICA-Dome $\mathrm{C}$ ice core contains ice of MIS 7 age, $\mathrm{CO}_{2}$ measurements for this time period have not yet been published. MIS 7c peaked at approximately 280ppm of $\mathrm{CO}_{2}$, while MIS $7 \mathrm{a}$ had an average $\mathrm{CO}_{2}$ value of $250 \mathrm{ppm}$. This compares with a pre-industrial peak value of $280 \mathrm{ppm}$ for MIS 1 (Petit et al., 1999). Deuterium $(\delta \mathrm{D})$ records of atmospheric temperature in the Vostok and EPICA Dome C ice cores show that the optimum warm period during MIS $7 \mathrm{c}$ was $2^{\circ} \mathrm{C}$ warmer, whist MIS 7a was $2^{\circ} \mathrm{C}$ cooler, than the Holocene optimum (Petit et al., 1999, Jouzel et al., 2007). 


\subsection{Stable Oxygen isotopes}

The oxygen isotope ratio $\left(\delta^{18} \mathrm{O}\right)$ incorporated into the skeletons of carbonate organisms is a function of two environmental parameters, the water temperature and the $\delta^{18} \mathrm{O}$ of the ocean, which in turn is dependent on ice volume and salinity (Shackleton, 1987). The Lisiecki Raymo 04 (LR04) stack of 57 benthic $\delta^{18} \mathrm{O}$ records provides a global average deep-water $\delta^{18} \mathrm{O}$ record for MIS 7 (Lisiecki and Raymo, 2005). Values across MIS 7c and 7a were more positive by approximately $0.25-0.5 \%$ o than the optima of MIS 1, 5, 9 and 11 . This suggests that either global ice volume was larger and/or deep water temperatures were cooler during MIS 7 than during other late Pleistocene interglacials (Lisiecki and Raymo, 2005).

\subsection{Orbital parameters and insolation}

Insolation describes the amount of incoming solar radiation reaching the top of Earth's atmosphere (Berger et al., 2007). The intensity of the solar radiation varies over time mainly due to variations in the orbital cycles of obliquity and precession, with a smaller direct impact from eccentricity as it modulates the amplitude of the precession cycle (Hays et al., 1976). For MIS 7 the eccentricity of the Earth's orbit was high, reaching 0.05 , which also resulted in higher amplitudes of precession, with the highest values reached in MIS 7a (Fig. 4.2) (Berger et al., 1992). The angle of obliquity decreased during the deglaciation from MIS 8 to MIS 7c, unlike other late Pleistocene deglaciations, which were coincident with the rising limb of the obliquity cycle (Huybers and Wunsch, 2005). Obliquity reached its lowest angle for MIS 7 of $22.08^{\circ}$ at $232 \mathrm{ka}$, during the transition into stadial MIS $7 \mathrm{~b}$ (Berger et al., 1992). The transition into interstadial MIS 7a coincided with increasing angles of obliquity, which reached a maximum of $24.48^{\circ}$ at $213 \mathrm{ka}$ (Berger et al., 1992). Precession reached a peak at $209 \mathrm{ka}$ of 0.049 , and this was coupled with high eccentricity and angle of obliquity, that collectively resulted in high insolation (Berger et al., 1992). 


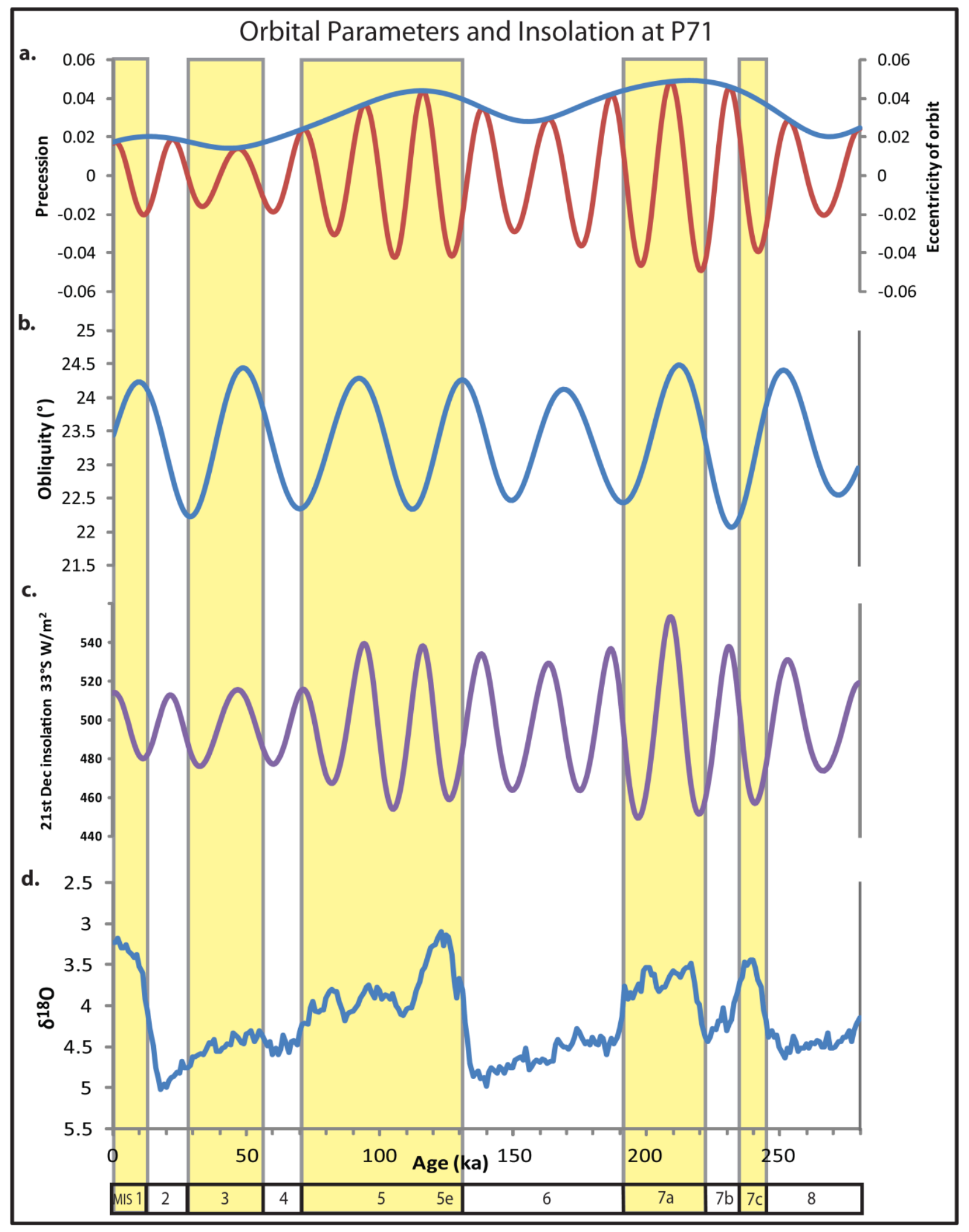

Figure 4.2. Orbital parameters of (a) eccentricity (blue) and precession (red), (b) obliquity, and (c) peak summer $\left(21^{\text {st }}\right.$ Dec.) insolation at $33^{\circ} \mathrm{S}$ for the past $280 \mathrm{kyr}$ from Berger et al. (1992). Benthic oxygen isotope stack from Lisiecki and Raymo (2005). 
At 210ka, during MIS 7a Southern Hemisphere peak summer insolation reached its highest point for the last 1 million years (Berger et al., 1992). Peak summer insolation intensity at $33^{\circ} \mathrm{S}$, the latitude of core site $\mathrm{P} 71$, was $553 \mathrm{~W} / \mathrm{m}^{2}, 39 \mathrm{~W} / \mathrm{m}^{2}$ higher than present values (Fig. 4.2), while at the latitude of ODP $1120,50^{\circ} \mathrm{S}$, insolation intensity was $560 \mathrm{~W} / \mathrm{m}^{2}, 43 \mathrm{~W} / \mathrm{m}^{2}$ higher than present (Berger et al., 1992). When summer insolation is high, the seasonal cycle is also amplified. For $33^{\circ} \mathrm{S}$ there was a $383 \mathrm{~W} / \mathrm{m}^{2}$ difference between mid-summer $\left(21^{\text {st }}\right.$ December) and mid-winter ( $21^{\text {st }}$ June) values at $210 \mathrm{ka}$, while at $197 \mathrm{ka}$ when peak insolation was low, the seasonal difference was $232 \mathrm{~W} / \mathrm{m}^{2}$ (Berger et al., 1992). The modern seasonal difference is $328 \mathrm{~W} / \mathrm{m}^{2}$ in comparison (Berger et al., 1992). When the precession component of insolation is highest, summer, defined as the number of days in the year above a certain value of insolation, is actually shorter than when insolation is low (Huybers, 2006). High insolation in MIS 7a would have resulted in intense irradiance, but short summers at both core sites (Berger et al., 1992). This study uses 'insolation' to refer to the peak summer $\left(21^{\text {st }}\right.$ Dec.) insolation intensity at the latitude of the core sites, as opposed to mean annual insolation.

\subsection{Ocean temperatures in the Southwest Pacific Ocean}

SSTs for MIS 7c and 7a in the South West Pacific Ocean from previous studies have been compared with the modern average annual sea surface temperatures (Fig. 4.3). During MIS 7c and MIS 7a, SAW was cooler than modern average SSTs by approximately $2{ }^{\circ} \mathrm{C}$ in MIS 7a, and $1{ }^{\circ} \mathrm{C}$ in MIS 7c (Pahnke et al., 2003, Hayward et al., 2008, Lüer et al., 2009). STW temperatures were comparable to or warmer than modern SSTs in both time periods, by up to $2^{\circ} \mathrm{C}$ in MIS 7a and $3.5-4^{\circ} \mathrm{C}$ in MIS 7c (Calvo et al., 2004, Pelejero et al., 2006, Hayward et al., 2008, Hayward et al., 2012). Exceptions to this trend are core sites E36-23 and MD062986, both of which sit near the STF, and show cooler waters during both time periods. SSTs 
to the north and south of the Tasman inflow were comparable during MIS 7a and modern times, but were cooler during MIS $7 \mathrm{c}$ by $1.5^{\circ} \mathrm{C}$ (Kawagata, 2001).
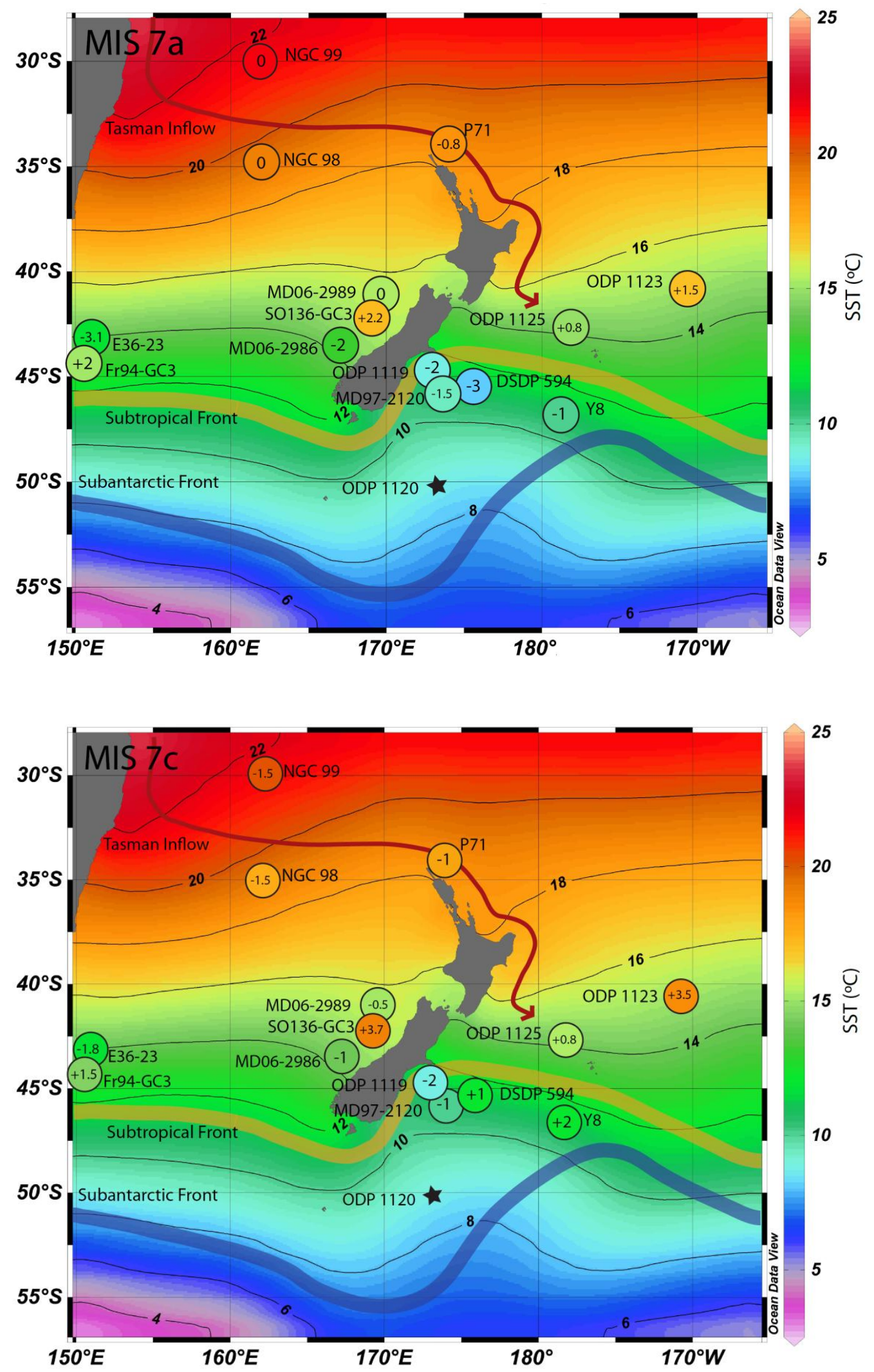
Figure 4.3. World Oceanographic Atlas 2009 mean annual SSTs around New Zealand (isotherms in degrees Celsius). Circles indicate cores with temperature data for MIS 7 with colours representing the corresponding temperatures for the core sites during MIS 7. Numbers within circles show the magnitude of temperature change from modern. Modern Analogue Technique analysis on foraminiferal assemblages is used to derive temperatures for ODP 1119, DSDP 594, ODP 1125 and ODP 1123 from Hayward et al. (2008), NGC 98 and 99 from Kawagata (2001), and MD06-2986 from Hayward et al. (2012). Temperatures for MD06-2989 are derived using Artificial Neural Network (ANN25) analysis from Hayward et al. (2012). Lüer et al. (2009) used transfer function radiolarian based sea surface temperature estimates for core Y8. Calvo et al. (2004) and Pelejero et al. (2006) used alkenone paleothermometer $U_{37}{ }^{K}$ to derive temperatures for SO136-GC3 and Fr94-GC3 respectively. MD97-2120 temperatures are obtained from Mg/Ca values from Pahnke et al. (2003) and calibrated to temperature based on Marr et al. (2011). Temperatures for E36-23 were derived using Random Forest modelling (RFM) by George Scott (GNS Science). P71 temperatures are also derived from RFM (this study). The modern positions of the SAF, STF and Tasman Inflow are blue, orange and red lines respectively.

\subsection{Sea level}

Various methods have been used to constrain global sea level during MIS 7 including: dating speleothem growth events from now submerged caves, dating of uplifted coral reefs and marine terraces, and ice volume determinations from $\delta^{18} \mathrm{O}$ ocean records (Siddall et al., 2007). However, there is still disagreement over the magnitude of global sea level change during this time period (Siddall et al., 2007). While there is variation in the estimates of sea level, most record the interstadials of MIS 7 as having equal, or lower than, present sea levels (Lea et al., 2002, Siddall et al., 2007, Dutton et al., 2009, Rohling et al., 2009). Most records 
do not estimate sea level during MIS 7c as being significantly higher than MIS 7a, with some suggesting comparable sea levels at both interstadials (Lea et al., 2002, Siddall et al., 2007, Dutton et al., 2009, Rohling et al., 2009). In New Zealand, Pillans et al. (1988) suggest that relative local sea level was higher in MIS 7a than in 7c. Overall, global sea levels were likely slightly lower than present, implying greater ice volume in the polar regions during MIS 7.

\subsection{Ice Rafted Debris}

Ice rafted debris (IRD) concentrations in marine sediment cores can be used to interpret the presence of icebergs (Grobe, 1987). However, the link between the physics of an ice sheet and an IRD signal are not fully understood and some assumptions are needed when interpreting IRD records. For example, assumptions include that all icebergs carry the same load of IRD, and higher IRD concentrations represent a greater iceberg flux to the site, as opposed to a greater inclusion of debris in the icebergs (Clark \& Pisias, 2000). More IRD may also reflect cooler ocean temperatures resulting in more icebergs reaching a site before they melt, or from changes in local current and wind patterns affecting the distribution of icebergs (Teitler et al., 2010). Records from around Antarctica, including the Weddell Sea, Amundsen Sea, the Southeast Atlantic and the Campbell Plateau, show enhanced IRD in MIS 7 relative to other interglacials in the late Pleistocene (Grobe and Mackensen, 1992, Kanfoush et al., 2002, Carter et al., 2002, Teitler et al., 2010). Grobe and Mackensen (1992), Kanfoush et al. (2002) and Teitler et al. (2010) attribute this peak to the magnitude of stadial $7 \mathrm{~b}$ during which cooler temperatures may have preserved icebergs, allowing them to travel further before melting and releasing IRD. However, peaks in IRD occur throughout MIS 7, particularly towards the end of MIS 7a (Grobe and Mackensen, 1992, Carter et al., 2002), and suggest a significant ice rafting event during this time period, the cause of which is still not fully understood. 


\subsection{Marine surface water productivity}

Different water masses record different rates of productivity during MIS 7. In polar waters near Antarctica, MIS 7 has a siliceous productivity signal greater or equal to other late Pleistocene interglacials (Grobe and Mackensen, 1992, Cortese and Gersonde, 2008, Hillenbrand et al., 2009). Hilllenbrand et al. (2009) noted that MIS 7a in the Amundsen Sea had the highest mass accumulation rates of biogenic opal and $\mathrm{Ba} / \mathrm{Al}$ in sediment, the latter being a proxy for surface water productivity (Gingele and Dahmke, 1994), for the last 0.9 Myr. Grobe and Mackensen (1992) also found high amounts of biosiliceous productivity in MIS 7a, which they attribute to high Southern Hemisphere insolation stimulating plankton growth. However, there are no significant peaks in productivity proxies from biogenic opal mass accumulation rates and coccolithophore assemblages throughout SAW during MIS 7 (Nelson et al., 1986, Flores et al., 2003, Cortese and Gersonde, 2008). STW also shows no significant productivity differences during MIS 7 compared to other late Pleistocene interglacials based on $\mathrm{Ba} / \mathrm{Al}$ and benthic and planktic foraminifera accumulation rates (Hall et al., 2001, Schaefer et al., 2005, Hayward et al., 2012,). Crundwell et al. (2008) found 10$15 \%$ more foraminifera that favour eutrophic (nutrient-rich) conditions during MIS $7 \mathrm{c}$ than during $7 \mathrm{a}$ at $\mathrm{ODP}$ site $1123\left(41^{\circ} 47.2^{\prime} \mathrm{S}, 171^{\circ} 29.9^{\prime} \mathrm{W}\right)$, implying this site was more nutrientrich and potentially more productive in MIS 7c. Kawagata (2001) suggests that waters in the Tasman Front had high phytoplankton production during MIS 7, determined from increases in total organic carbon mass accumulation rates and Q-mode principal component analysis on benthic foraminifera assemblages.

\subsection{Terrestrial climate}

Pollen provides information on terrestrial climate by comparing fossil assemblages to present vegetation distributions (Heusser and van de Geer, 1994). Records from Auckland, Taranaki, 
Wanganui and Wellington in the North Island of New Zealand suggest that MIS 7a was warm and wet, with temperatures and rainfall similar to present (Pillans et al., 1988, Mildenhall, 1995, Bussell and Pillans, 1997, Marra et al., 2006). The Auckland record, based on both fossil pollen and beetle species assemblages, suggests that temperatures were comparable to present, or potentially slightly cooler $\left(<1^{\circ} \mathrm{C}\right)$ at the end of MIS 7a (Marra et al., 2006). Pollen from Taranaki and Wellington also record MIS 7c. The record at Petone, Wellington, suggests that it was warm, moist and similar to MIS 7a (Mildenhall, 1995), while in Taranaki it was cooler and dryer than MIS 7a (Bussell and Pillans, 1997). Stadial MIS 7b is also recorded at Taranaki, Wanganui and Wellington as a cool, wet and frosty period with estimated temperatures at Wanganui $3^{\circ} \mathrm{C}$ below present (Pillans et al., 1988, Mildenhall, 1995, Bussell and Pillans, 1997). In the South Island, a record from Banks Peninsula does not separate MIS 7 into substages, but shows the period to have comparable climate to MIS 5e and the Holocene optimum, but with some cool and wet intervals (Shulmeister et al., 1999, Soons et al., 2002). Offshore, Deep Sea Drilling Project (DSDP) site 594 at the head of the Bounty Trough has a continuous pollen record extending back to MIS 9 (Heusser and van de Geer, 1994). During MIS 7a and 7c the abundance of montane and sub-alpine pollen indicate that MIS 7 was the coolest interglacial of MIS 1, 5, 7 and 9, with estimated temperatures $\sim 3^{\circ} \mathrm{C}$ cooler than present for MIS $7 \mathrm{a}$ and $7 \mathrm{c}$, and even cooler again for $7 \mathrm{~b}$ (Heusser and van de Geer, 1994). This conflicts with the Banks Peninsula record of Shulmeister et al. (1999). To account for this, Soons et al. (2002) suggest that DSDP 594 reflects a more southerly catchment for the fluvial and aeolian-derived pollen during MIS 7.

\subsection{MIS 7 summary}

Records of MIS 7 around New Zealand are limited, and there are no marine records that encompass MIS 7 near the core sites of P71 and ODP 1120. By using data from cores within 
the same water masses some inferences can be made about general conditions at each site. The Tasman Inflow had cooler SST's than present during MIS 7c, but was comparable to present in MIS 7a, and productivity in the Tasman Front was enhanced during MIS 7 (Kawagata, 2001). In SAW, SSTs were comparable or slightly cooler that modern during MIS 7c, and cooler than modern in MIS 7a (Pahnke et al., 2003, Hayward et al., 2008, Lüer et al., 2009, Marr et al., 2011), and productivity was comparable to present (Nelson et al., 1986, Flores et al., 2003, Cortese and Gersonde, 2008). 


\section{ECOLOGY OF FORAMINIFERA AND COCCOLITHOPHORES}

\subsection{Ecology of Foraminifera}

The trace element and stable isotopic chemistry of foraminifera has been used in this study for paleoceanographic interpretations and to determine an age model for each core. This section describes the ecology of the foraminifera species used in this study, three planktic species Globigerina bulloides, Globigerinoides ruber and Globorotalia inflata, and two benthic species Cibicidoides wuellerstorfi and Uvigerina peregrina (Fig. 5.1).

G. bulloides (d'Orbigny, 1826) is a spinose, non-symbiont bearing planktic foraminifera (Hemleben et al., 1989). It is a subtropical to polar dwelling species found above 400m depth, but mainly between 25-150m (Saito et al., 1981, Hemleben et al., 1989, Mortyn and Charles, 2003, Neil et al., 2004). It dominates in SAW, and often exceeds 50\% of the total foraminifera population (Bé and Tolderlund, 1971). It lives in temperatures ranging from 0$27^{\circ} \mathrm{C}$, with peak abundances occurring between $3-19^{\circ} \mathrm{C}$ (Bé and Tolderlund, 1971). G. bulloides is a eutrophic species and its abundance is controlled primarily by nutrient availability as opposed to temperature (Hemleben et al., 1989, Schiebel et al., 2001, Crundwell et al., 2008). For this reason it is often associated with areas of upwelling where nutrient-rich waters at depth are entrained into the mixed layer, and frontal zones, such as the STF, where the mixing of different water masses creates nutrient-rich productive zones (Hemleben et al., 1989, King and Howard, 2001, Murphy et al., 2001, Schiebel et al., 2001)

G. ruber (white, d'Orbigny, 1839a) is a spinose planktic foraminifera, which bears dinoflagellate symbionts (Bé et al., 1977, Hemleben et al., 1989, Dekens et al. 2002). It lives in equatorial to temperate waters and is the most prolific planktic foraminifera in subtropical waters (Bé and Tolderlund, 1971, Saito et al., 1981). G. ruber (white, d'Orbigny) can be 
defined as sensu stricto and sensu lato, when two widely recognised morphotypes (G. ruber ruber and G. ruber pyramidalis e.g. Saito et al., 1981) are grouped together as G. ruber. A study by Mohtadi et al. (2009) of sediment trap samples off Java found both sensu stricto and sensu lato to be geochemically similar, so this study has not differentiated between them. Similarly, Bolton et al. (2011) found no difference between G. ruber ruber and G. ruber pyramidalis. G. ruber also has a white and a pink variety. Pink G. ruber became extinct in the Pacific at $120 \mathrm{kyr}$, so for consistency through time, this study utilises the white form of $G$. ruber, which inhabits slightly cooler temperatures than the pink form (Thompson et al., 1979, Hemleben et al., 1989). G. ruber's living temperature range is between $14-30^{\circ} \mathrm{C}$, with peak abundances occurring between $21-29^{\circ} \mathrm{C}$ (Bé and Tolderlund, 1971). Salinity is not a limiting factor; laboratory tests have shown it can live in salinities that range from 22-49 psu (Hemleben et al., 1989, Bijma et al., 1990). It dwells within the photic zone due to the presence of photosynthetic symbionts (Hemleben et al., 1989). As it is such a shallow dwelling ( 0-50m) species, it is considered a suitable species to study surface water conditions (Hemleben et al., 1989, Dekens et al., 2002).

Globorotalia inflata (d'Orbigny, 1839b) is a non-spinose planktic foraminifera which can be symbiont-bearing (Hemleben et al., 1989). In plankton tows, the highest abundances are between 50-600m depth (Bé and Tolderlund, 1971, Mortyn and Charles, 2003, Neil et al., 2004), and it is usually considered a thermocline dwelling species (Neil et al., 2004). G. inflata is a temperate to subpolar species that can live in sea surface temperatures ranging from $1-27^{\circ} \mathrm{C}$, but is most abundant from $13-19^{\circ} \mathrm{C}$ (Bé and Tolderlund, 1971, Saito et al., 1981).

Uvigerina peregrina (d'Orbigny, 1826) is a shallow infaunal benthic foraminifera (Murray, 1991). It is abundant in oxygen deficient substrates where the organic carbon flux is high 
throughout the year (Hayward et al., 2002). The geochemistry of the test reflects that of the pore water in which it calcified, but the pore water microenvironment is also governed by macrofaunal burrows, which can incorporate bottom waters further into the sediment (Loubere et al., 1995). The oxygen isotopes $\left(\delta^{18} \mathrm{O}\right)$ are used from this species as the carbon isotopes $\left(\delta^{13} \mathrm{C}\right)$ are altered by the microenvironment (McCorkle et al., 1990). It lives in cold water, at depths around New Zealand of 50-5000m, peaking in abundance at $800-4500 \mathrm{~m}$ (Murray, 1991, Hayward et al., 2010), although ultimately its living depth range is limited by the carbonate compensation depth which varies from $3700-4600 \mathrm{~m}$ in the Southwest Pacific (Bostock et al., 2011).

Cibicidoides wuellerstorfi (Schwager, 1866) is an epifaunal benthic foraminifera (Murray, 1991). Other common names include Cibicides, Fontbotia and Planulina, but this study refers to these foraminifera as Cibicidoides spp. following the nomenclature of Schweizer et al. (2009). It prefers attachment to a hard substrate but can be free-floating (Murray, 1991). It lives in cold water, at depths of 400-3000m around New Zealand (Murray, 1991, Hayward et al., 2010). The $\delta^{18} \mathrm{O}$ from Cibicidoides spp. is offset from equilibrium (Shackleton and Opdyke, 1973), while the $\delta^{13} \mathrm{C}$ is usually in equilibrium with the bottom water $\delta^{13} \mathrm{C}$ of dissolved inorganic carbon (Zahn et al., 1986, McCorkle et al., 1990). 


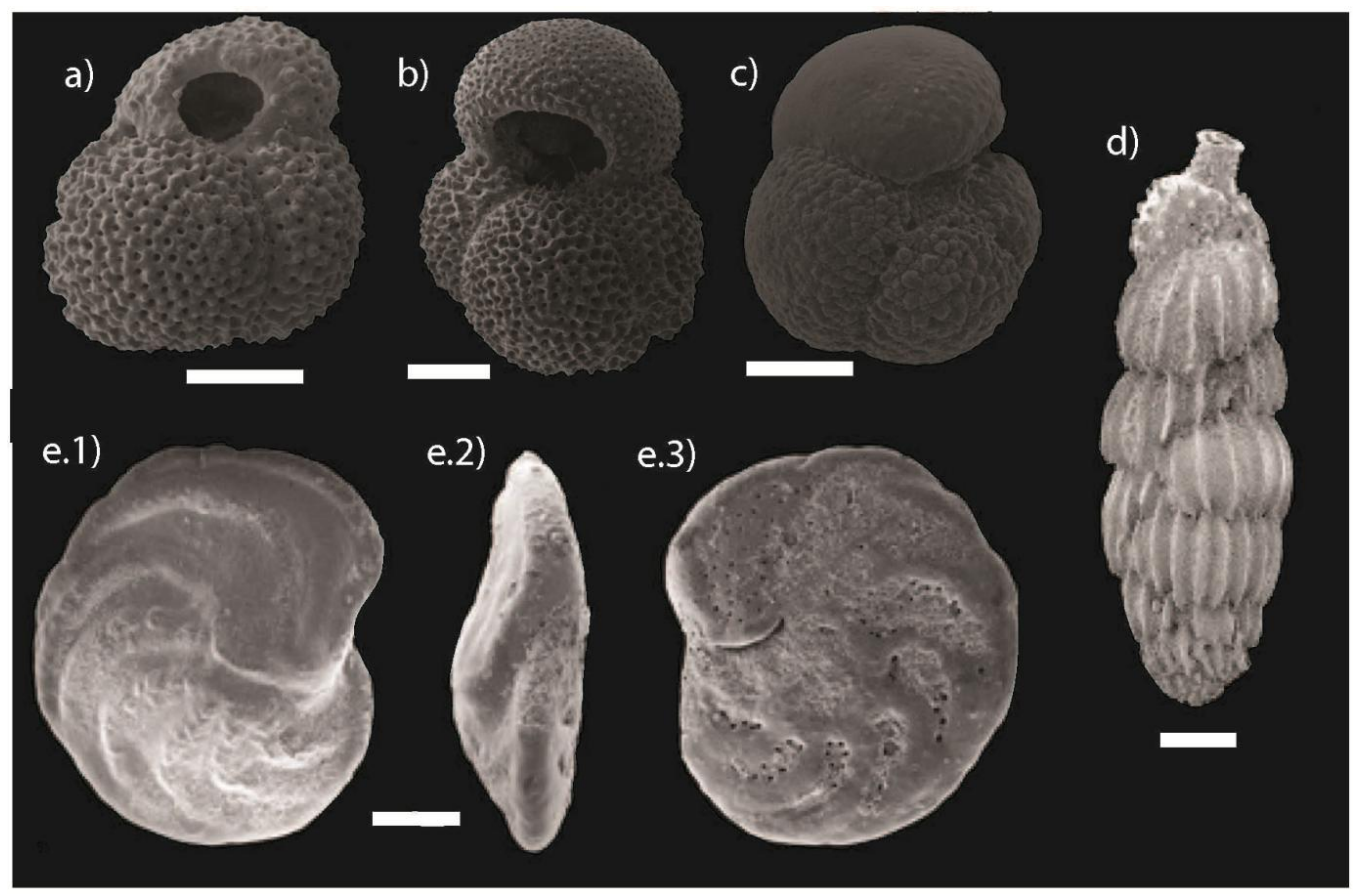

Figure 5.1. Scanning Electron Microscope images of foraminifera used in this study. A) Globigerinoides ruber, B) Globigerina bulloides, C) Globorotalia inflata (Images sourced from Marr (2009)), D) Uvigerina peregrina (Image from Schwerizer et al. (2005), E) Cibicidoides wuellerstorfi e.1) top, e.2) side, e.3) bottom (Image from Schweizer et al. (2009). Scale bar is $100 \mu m$.

\subsection{Ecology of Coccolithophores}

Coccolithophores play an important role in the marine carbon cycle as they are the most productive calcifying organisms on Earth (Rost and Riebesell, 2004). Our understanding of coccolithophore distribution and responses to environmental change is limited however and requires further research (Rost and Riebesell, 2004, Zondervan, 2007). Coccolithophore blooms cause a rapid increase in biomass due to a local increase in primary production (Legendre, 1990). The two dominant species/genera in P71 identified from Scanning Electron Microscopy (SEM) are Emiliania huxleyi and Gephyrocapsa spp. in particular Gephyrocapsa oceanica (Fig. 5.2). These are the most prominent bloom-forming coccolithophores at 
present, e.g. E. huxleyi can generate up to $10^{7}$ cells $\mathrm{L}^{-1}$ (Tyrrell and Merico, 2004, Rost and Riebesell, 2004, Trimborn et al., 2007) and are also the most abundant coccolithophores in the waters around New Zealand, with G. oceanica more dominant in the north, and E. huxleyi more dominant in the south (Rhodes et al., 1995, Hoe Chang, NIWA, pers. comm.). E. huxleyi accounts for over $50 \%$ of the coccolithophore flora in the mid-latitudes, reaching close to $100 \%$ in high latitudes (McIntyre and Bé, 1967). Sediment trap data shows that the peak in the flux of E. huxleyi and G. oceanica through the water column is often correlated with annual peaks in the total biogenic flux (Andruleit et al., 2000, Herbert, 2003).

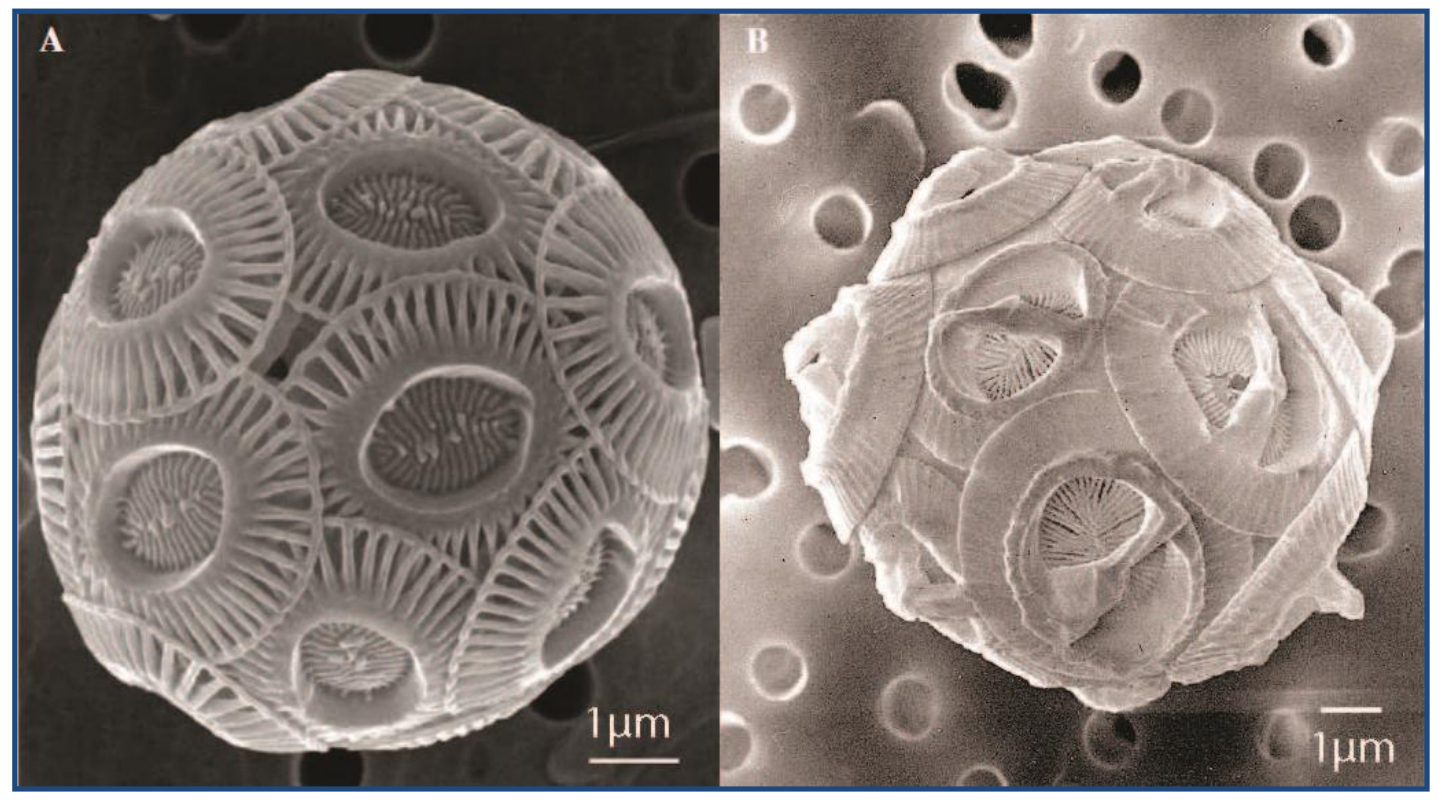

Figure 5.2. Coccospheres of E. huxleyi (a) and G. oceanica (b) from Cros and Fortuña (2002). Coccoliths of E. huxleyi consist of placoliths joined by rods, whereas those of G. oceanica have a central area with a bridge, which aligns almost perpendicular to the long axis of the coccolith.

Herrmann et al. (2012) determined SST's from the distribution of coccoliths (the individual platelets that form a coccolithophores coccosphere (Fig. 5.2)) in surface sediment samples. They found E. huxleyi in sediments with associated SSTs of $6-29.4^{\circ} \mathrm{C}$. McIntyre and Bé 
(1967) and Holligan et al. (2010) found E. huxleyi at cooler temperatures of $<2{ }^{\circ} \mathrm{C}$, but in low abundances. Herrmann et al. (2012) showed Gephyrocapsa spp. also tolerated a range of temperatures from $6-29.4^{\circ} \mathrm{C}$. Different species of Gephyrocapsa have different temperature ranges; G. oceanica is a warm water species, concentrated at lower latitudes and in the Southern Hemisphere is most abundant around the $15^{\circ} \mathrm{C}$ isotherm, while G. mullerae and $G$. ericsonni are both cooler water species (Ziveri et al., 2004, Holligan et al., 2010). G. caribbeanica lives between $5-21^{\circ} \mathrm{C}$, with a maximum abundance between $13-19^{\circ} \mathrm{C}$ (Bollmann, 1997). However, changes in temperature per se, are not thought to be a significant causal factor in the formation of coccolithophore blooms (Tyrrell and Merico, 2004).

Coccolithophore blooms of E. huxleyi occur where there is higher than average light intensity (Tyrrell and Merico, 2004, Zondervan, 2007). E. huxleyi appears resistant to photoinhibition at high light levels, and so can grow during high light saturation in the upper water column (Tyrrell and Merico, 2004, Trimborn et al., 2007). This is in contrast to other phytoplankton, which are less tolerant of high light levels (Tyrrell and Merico, 2004). Day length is also important for the growth of coccolithophores. E. huxleyi reaches blooming concentrations and maximum growth rates when day lengths approach 16 hours (Balch, 2004). In laboratory experiments, G. oceanica had a higher growth rate during 14 hour days, than during continuous 24 hour light (Brand and Guillard, 1981). This suggests that coccolithophores have preferences for certain light:dark ratios, which may relate to the day length of the season whose conditions most favour their growth (Balch, 2004).

Coccolithophores require a stratified uppermost ocean to bloom where the mixed layer depth is $\sim 10-20 \mathrm{~m}$ and always $<30 \mathrm{~m}$ (Head et al., 1998, Tyrrell and Merico, 2004, Trimborn et al., 2007, Iida et al., 2012). Stratification, predominantly driven by wind and temperature, results 
in high average light intensity in the mixed layer (Tyrrell and Merico, 2004). High coccolithophore concentrations also promote stratification as the coccolith platelets reflect the light entering the water, resulting in brighter and more intensely heated water in the upper few metres, and cooler darker waters below (Tyrrell et al., 1999).

Gephyrocapsa spp. favours nutrient-rich environments whereas E. huxleyi can bloom in both eutrophic (nutrient-rich) and oligotrophic (nutrient-poor) environments (Ziveri et al., 2004, Tyrrell and Merico, 2004, Boeckel et al., 2006). E. huxleyi has the highest phosphate assimilation capability of all phytoplankton (Riegman et al., 2000). It has a low uptake rate of nitrate and is a poor competitor under conditions of nitrate limitation (Riegman et al., 2000, Zondervan, 2007). Therefore phosphate is more of a limiting nutrient than nitrate, and $E$. huxleyi blooms often, but not always, occur in waters which are nitrate-rich but phosphatepoor (Tyrrell and Merico, 2004, Zondervan, 2007). While blooms can occur in eutrophic environments, coccolithophores are also adapted to low nutrient environments and favour stratified waters, which typically have limited nutrient availability (Baumann et al., 2004, Rost and Riebesell, 2004). E. huxleyi also requires trace metals for growth and reproduction such as iron, zinc cobalt, selenium, cadmium and manganese (Brand et al., 1983, Zondervan, 2007). Iron has a low abundance is seawater, but is the most abundant trace metal in phytoplankton where it is required for photosynthesis, so areas where aeolian or waterborne deposition of iron occurs are important for productivity (Zondervan, 2007). E. huxleyi and G. oceanica have a low requirement for iron, and in high latitudes blooms typically occur when surface iron has been depleted by other phytoplankton (Zondervan, 2007, Holligan et al., 2010). E. huxleyi has a low requirement for manganese relative to other phytoplankton (Zondervan, 2007). Its affinity for zinc is comparable to other oceanic phytoplankton species and it is potentially a limiting micronutrient, but the role of zinc is still debated (Rost and Riebesell 2004, Zondervan, 2007). 
Diatoms often dominate eutrophic environments that are rich in silicate, so E. huxleyi is most productive in environments where nitrate and phosphate are available, but silicate has been exhausted, preventing the growth of diatoms (Tyrrell and Merico, 2004). Diatoms bloom in early spring when the mixed layer shallows, but is still rich in nutrients from winter mixing, and critical irradiances allow phytoplankton growth (Legendre, 1990). Blooms of coccolithophores usually follow diatom blooms in late spring and early summer when light levels are high and the water column is stratified and often depleted in nutrients (Tyrrell and Merico, 2004, Zondervan, 2007, Holligan et al., 2010). This sequence of phytoplankton blooming is also the case offshore New Zealand (Sikes et al., 2005, Hoe Chang, NIWA, pers. comm.). Stratified waters also prevent upwelling of silicate-rich waters, inhibiting the growth of diatoms (Iida et al., 2012). A coccolithophore bloom requires a rate of growth that exceeds the rate at which it can be grazed by predators like micro-zooplankton (Olson and Strom, 2002).

To reach bloom conditions, the growth rate of coccolithophores must exceed their mortality rate, and the rate at which they are grazed by zooplankton (Rost and Riebesell, 2004). Grazing balances the growth of phytoplankton in winter, but in spring, growth exceeds the rate of grazing and blooms are able to form (James and Hall, 1998, Bradford-Grieve et al., 1998). Blooms may also coincide with times where there are other sources of food for zooplankton, or zooplankton themselves are being grazed (Rost and Riebesell, 2004). For example blooms of E. huxleyi have been found to occur when copepods are grazing on microzooplankton, reducing grazing pressure on organisms lower in the food web, such as coccolithophores (Nejstgaard et al., 1997). In the Bering Sea, reduced mortality of coccolithophores as a result of microzooplankton grazing has been found to be an important component in the formation and persistence of an E. huxleyi bloom (Olsen and Strom, 2002). 
Calcite saturation state is also important in determining where coccolithophore blooms can occur. Increasing undersaturation presents a kinetic barrier to the calcification of robust coccoliths (Tyrrell and Merico, 2004). This also contributes to the absence of coccolithophores at polar latitudes where the surface waters have the lowest calcite saturation state (Tyrrell and Merico, 2004). The reaction of coccolithophores to current environmental change is a key issue, as coccolithophores play an important role in the carbon cycle (Rost and Riebesell, 2004). Beaufort et al. (2011) investigated how increasing $\mathrm{CO}_{2}$ may affect the calcification of coccolithophores using core top and sediment samples from modern times back to MIS 2. They found that calcification of E. huxleyi decreased with increasing partial pressure of $\mathrm{CO}_{2}$ as this led to a decrease in concentration of $\mathrm{CO}_{3}{ }^{2-}$. However they also found evidence of a highly calcified morphotype of E. huxleyi in $\mathrm{CO}_{2}$-rich waters with a $\mathrm{pH}$ of 7.77.8 suggesting that the species response to increasing $\mathrm{CO}_{2}$ and resultant ocean acidification will not be straightforward. This is supported by laboratory experiments suggesting increased coccolith volume at high $\mathrm{CO}_{2}$ levels (Müller et al., 2012). Iglesias-Rodríguez et al. (2008) used coccolithophores from times of high $\mathrm{CO}_{2}$ in the geologic past, and culture experiments, to conclude that coccolithophores may be resilient to high levels of $\mathrm{CO}_{2}$, and coccolith mass may increase despite a decrease in saturation state. A study by Lohbeck et al. (2012) investigated the evolutionary capability of E. huxleyi to increased $\mathrm{CO}_{2}$ concentrations over $\sim 500$ generations, and found that growth rates increased and this species adapted quickly to ocean acidification. Different species have different reactions to higher $\mathrm{CO}_{2} ;$ Calcidiscus leptoporus shows malformation and decreased calcification with both higher and lower $\mathrm{CO}_{2}$ than present in short laboratory experiments (Langer et al., 2006). However, geological evidence from marine sedimentary cores suggest that this species has adapted to different $\mathrm{CO}_{2}$ levels over time in the past, and that its' reaction to $\mathrm{CO}_{2}$ concentration changes in the future may depend on the time scale of the change (Langer et al., 2006). It is also possible 
that increasing $\mathrm{CO}_{2}$ levels could increase photosynthesis of species such as E. huxleyi and $G$. oceanica as this process is carbon limited in the present ocean (Rost and Riebesell, 2004). Photosynthesis in other phytoplankton such as diatoms is less sensitive to $\mathrm{CO}_{2}$ changes, and so increasing $\mathrm{CO}_{2}$ may improve photosynthesis of fast growing, and fast adapting, coccolithophores like E. huxleyi, potentially giving them an ecological advantage (Rost and Riebesell, 2004).

There are other effects of warming that may favour the formation of coccolithophore blooms. Warming of the upper ocean and lowered surface salinity from increased fresh water input and reduced sea ice at the poles could result in enhanced global upper ocean stratification (Jacobs et al., 2002, Rost and Riebesell, 2004). This could limit nutrient supply and increase light levels in the upper mixed layer, resulting in an overall decline in primary productivity and a poleward shift to a longer growing season, which may be advantageous to coccolithophores at the expense of diatoms (Rost and Riebesell, 2004). Cubillos et al. (2007) studied a transect south of the Tasmania from the 1983 to 2006. E. huxleyi was absent or sparse during the 1980's and 1990's but was consistently present during the 2000's, suggesting a shift in the Southern Ocean ecology of this species over the past few decades.

Based on the present literature, the interplay of light levels, stratification, nutrients and competition with other phytoplankton species, appears to be the main causes for coccolithophores blooms, with SST less likely to be a significant factor. For a bloom to form, the rate of coccolithophore growth must also exceed the rate at which it is grazed. There is still debate on how coccolithophores may react to the present phase of climate change. It is not yet fully understood how the effects of an increase in $\mathrm{CO}_{2}$ concentrations on calcification and photosynthesis, coupled with changing upper ocean stratification and light conditions, will impact on coccolithophores. 


\section{METHODS}

\subsection{Core sampling}

Core P71 was sampled at $1 \mathrm{~cm}$ intervals. The outer edge of the core material was scraped off to reduce contamination from mud sliding along the core barrel, leaving the undisturbed inner material for sampling. ODP 1120 (core C) was sampled at $2.5 \mathrm{~cm}$ intervals and ordered from the Ocean Drilling Program core repository at College Station in Texas, USA (http://iodp.tamu.edu/curation/repositories.html). This study also made use of existing samples at National Institute of Water and Atmospheric Research (NIWA) (Wellington). The difference in sampling locations and access to available samples accounts for different sampling intervals for P71 and ODP 1120. The sampling intervals were considered to be adequate to gain the temporal resolution required for the study. Certain analyses were done on P71 but not on ODP 1120 due to the time constraints of the study.

\subsection{Sieving for foraminifera size fractions: P71}

Approximately $2 \mathrm{~g}$ of every second sample of the core was wet weighed and dried over night in a $40^{\circ} \mathrm{C}$ oven, then reweighed to determine a dry weight. Samples were disaggregated in a buffered solution of $1 \mathrm{~g} \mathrm{NaHCO}_{3}+0.25 \mathrm{~g} \mathrm{Na}_{2} \mathrm{CO}_{3}$ in 5 litres of distilled water, to create a solution with a $\mathrm{pH}$ of approximately 8.5, following the method of Dudley and Nelson (1989). This was to prevent possible dissolution of the calcareous nannofossils in the sample. The sample was agitated on a sieve shaker for 30 minutes to aid dispersal, before being washed with buffered solution through a $63 \mu \mathrm{m}$ sieve to separate the mud from the sand fraction. The $<63 \mu \mathrm{m}$ fraction was covered and left to settle for two days. The buffered solution was then siphoned off and the sediment dried in a $40^{\circ} \mathrm{C}$ oven and weighed. The $>63 \mu \mathrm{m}$ fraction was placed on filter paper and dried overnight in a $40^{\circ} \mathrm{C}$ oven. This was then dry sieved through a $150 \mu \mathrm{m}$ sieve, and the $63-150 \mu \mathrm{m}$ and $>150 \mu \mathrm{m}$ components were weighed. The $>150 \mu \mathrm{m}$ 
component was further sieved through $300 \mu \mathrm{m}$ and $355 \mu \mathrm{m}$ sieves to collect the $150-300 \mu \mathrm{m}$, 300-355 $\mu \mathrm{m}$ and $>355 \mu \mathrm{m}$ fractions for geochemical analysis. Sieve data is tabulated in Appendices 1.1-1.2.

\subsection{Picking foraminifera: P71}

Four foraminifera species were picked from the 300-355 $\mu \mathrm{m}$ size range, for every fourth sample for the whole core, and every second sample from $168-169 \mathrm{~cm}$ to $256-257 \mathrm{~cm}$, the depth of the core considered to be representative of MIS 7. A tight size range of 300-355 $\mu \mathrm{m}$ was used as the $\mathrm{Mg} / \mathrm{Ca}, \delta^{18} \mathrm{O}$ and $\delta^{13} \mathrm{C}$ values of foraminifera can vary depending on their size (Elderfield et al., 2002). The two planktic species were Globigerina bulloides and Globigerinoides ruber for stable isotope analysis and trace element geochemistry. The two benthic species were Uvigerina peregrina and Cibicidoides wuellerstorfi for stable isotope analysis. Approximately 25-45 planktic individuals and 3-5 benthic individuals were picked from each sample, with the numbers of picked specimens recorded so they could be accounted for in census work.

\subsection{Stable Oxygen and Carbon Isotope Stratigraphy: P71}

To prepare foraminifera for stable isotope analysis, groups of individuals from each different species from each sample were immersed in ultraclean (18 Mohm) MilliQ water in a $1.5 \mathrm{ml}$ centrifuge tube, and ultrasonicated at a low $20 \%$ power setting for $2-3$ seconds to remove adhering debris from the tests. The supernatant MilliQ was pipetted off. A clean aliquot of MilliQ was added and pipetted off three times, then foraminifera were placed on a slide, cleaned with compressed air, and left to dry over night.

Stable Isotope measurements were run by Dr Helen Neil at NIWA (Wellington). Samples were reacted with three drops of $\mathrm{H}_{3} \mathrm{PO}_{4}$ at $75^{\circ} \mathrm{C}$ in an automated individual-carbonate 
reaction (Kiel 111) device coupled with a Finnigan MAT252 mass spectrometer. Values of $\delta^{18} \mathrm{O}$ and $\delta^{13} \mathrm{C}$ on foraminifera are relative to $\mathrm{vPDB}$, where $\delta^{18} \mathrm{O}$ has a value of $-2.20 \%$ and $\delta^{13} \mathrm{C}$ has a value of $1.95 \%$ for NBS19 calcite. Internal precision of the measurements is 0.02 $0.08 \%$ for $\delta^{18} \mathrm{O}$ and $0.01-0.06 \%$ for $\delta^{13} \mathrm{C}$. External precision is $0.03 \%$ o for $\delta^{18} \mathrm{O}$ and $0.02 \%$ 。 for $\delta^{13} \mathrm{C}$. Stable isotope data can be found in Appendix 1.4.

This study was given access to $\delta^{18} \mathrm{O}$ for ODP 1120 that had been previously analysed at NIWA (Wellington). The first 300cm of this record were published in Neil et al. (2004). Data from $300-466 \mathrm{~cm}$ is unpublished.

\subsection{Trace element geochemistry: $P 71$}

G. ruber was chosen for trace element geochemistry, as a Southwest Pacific calibration for converting the $\mathrm{Mg} / \mathrm{Ca}$ ratio of the different chambers of this species into temperature was recently published by Bolton et al. (2011). Twelve samples were chosen down core to encompass MIS 7 as well as a sample from MIS 6 and MIS 8, and a near core top sample to compare to the modern mean annual temperature from the P71 core site. The samples had previously been ultrasonically cleaned for stable isotope analysis, but to further prepare them for trace element geochemistry the foraminifera were placed in a Petri dish and covered in analytical reagent grade methanol (e.g. Sadekov et al., 2010). The samples were ultrasonicated for 2-3 seconds, the excess methanol was pipetted off and the samples then dried in a $40^{\circ} \mathrm{C}$ oven over night.

The samples were mounted using methanol onto the adhesive side of sticky note paper, attached to a National Institute of Standards and Technology (NIST) 610 laser ablation standard glass disk (Fig. 6.1). Three chambers are commonly used for trace element analysis on G. ruber: "F-2" is the antepenultimate chamber formed during the growth cycle, "F-1" is 
the penultimate chamber and " $F$ " is the final chamber (Bolton et al., 2011). The chambers chosen for ablation in this study were the F-1 or F-2 chamber. The trace element ratios between these chambers are not statistically different, so it was not considered significant to consistently only ablate either the F-1 or F-2 chamber on each individual (Bolton et al., 2011). Each individual was analysed for ${ }^{24} \mathrm{Mg},{ }^{27} \mathrm{Al},{ }^{55} \mathrm{Mn},{ }^{66} \mathrm{Zn},{ }^{88} \mathrm{Sr},{ }^{138} \mathrm{Ba}$ and ${ }^{43} \mathrm{Ca}$, using a New Wave deep UV (193nm) solid state laser ablation system coupled to an Agilent 7500CS ICP-MS. Measurements were standardised by comparing to the published elemental compositions of the NIST 610 standard (Pearce et al., 1997). The ICPMS was tuned using a NIST 610 standard, carrier gas (Ar) amounts of 0.85-0.9 L/min and ablation gas (He) amounts of $88.5-95 \%$. At the beginning and end of each run, and in between samples, a background measurement was made for 90 seconds and a NIST 610 measurement for 60 seconds, with a 30 second wash-out period in between. For the NIST 610, a laser spot size of $35 \mu \mathrm{m}$ was used with a repetition rate of $5 \mathrm{~Hz}$. Measurements on foraminifera were made for 60 seconds with 30 second washouts in between measurements. For foraminifera a laser spot size of $35 \mu \mathrm{m}$ and a repetition rate of $5 \mathrm{~Hz}$ was also used. Trace element data were background corrected and normalised to Ca using a VUW written MATLAB script.

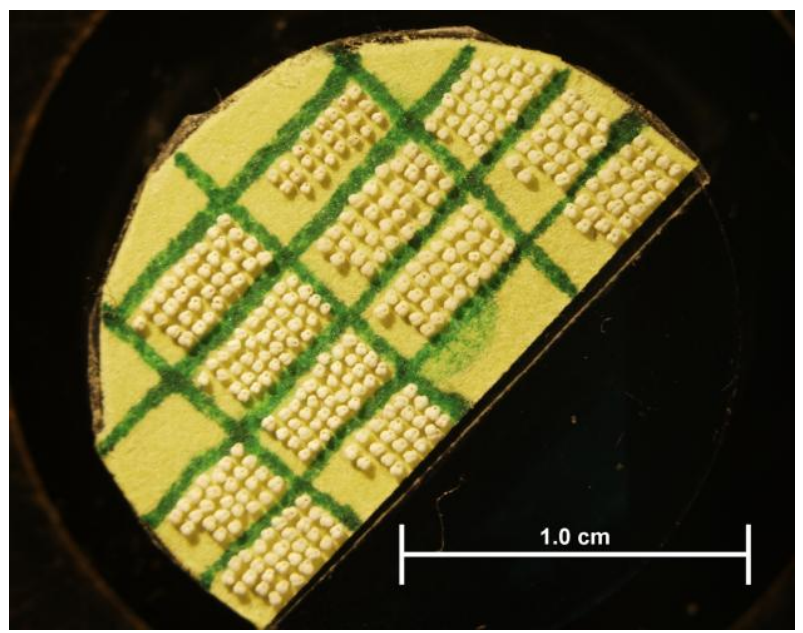

Figure 6.1: Foraminifera mounted on adhesive paper, on a NIST 610 standard, for trace element analysis. 


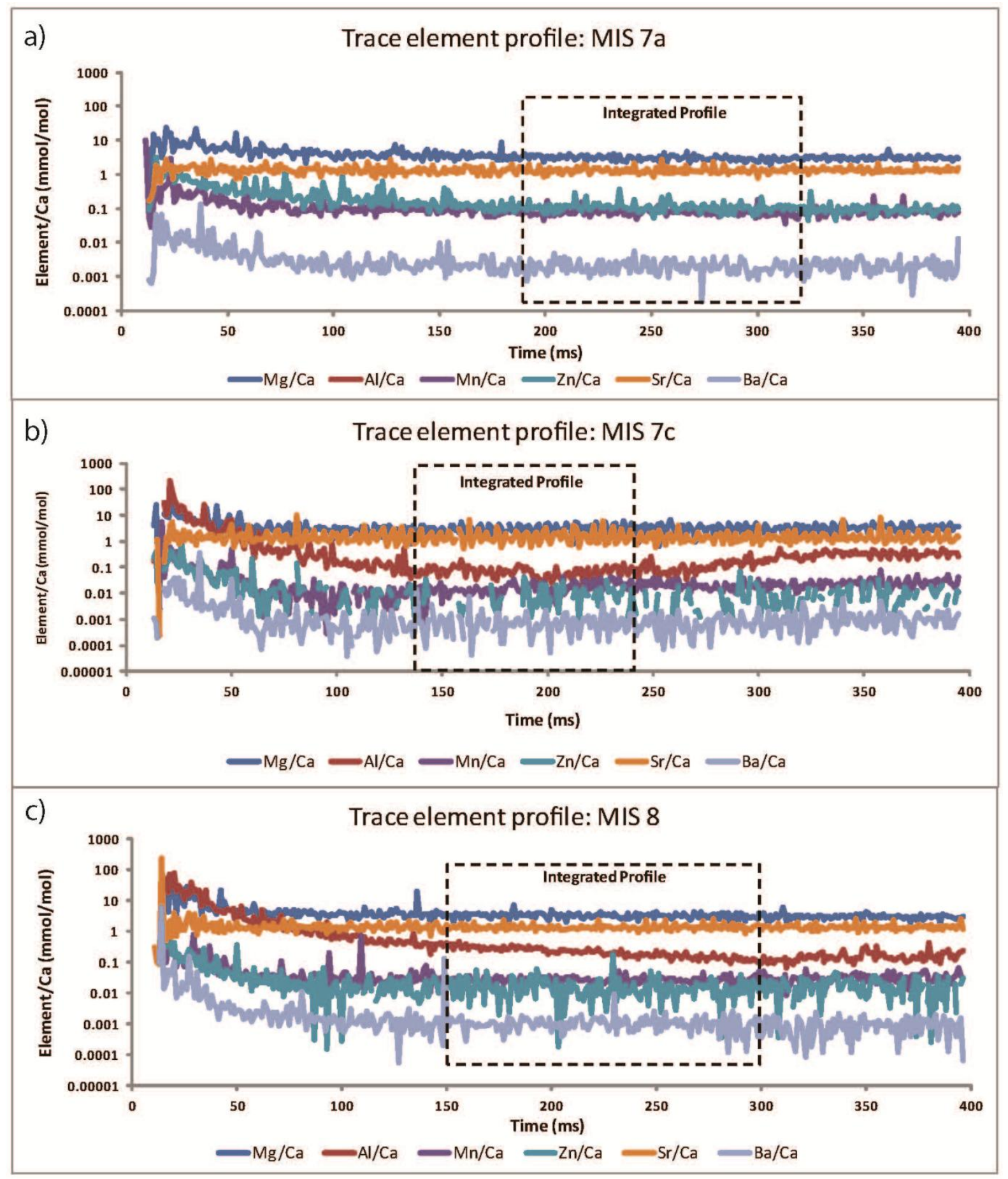

Figure 6.2: Trace element profiles of foraminifera from P71 samples representing MIS 7a at 209ka (a), MIS 7c at $241 \mathrm{ka} \mathrm{(b)} \mathrm{and} \mathrm{MIS} 8$ at $250 \mathrm{ka}(\mathrm{c})$.

Integrated profiles were selected from the trace element profiles of each foraminifera (Fig. 6.2). Trace element abundances were determined from those sections of the ablation profiles that were stable, and individual points within these sections considered outliers i.e. were markedly higher or lower than the bulk of the individual values in the sample, were not 
considered in sample averages. ${ }^{27} \mathrm{Al}$ was not measured on all samples due to technical difficulties. Figure 6.2 (b) shows a profile with oscillations due to the pulse rate of the laser being slow compared with the flow rate from the laser into the ICP-MS. However, the average $\mathrm{Mg} / \mathrm{Ca}$ value from this profile is $3.1 \mathrm{mmol} / \mathrm{mol}$, which converts to a temperature of $20^{\circ} \mathrm{C}$ following the $\mathrm{Mg} / \mathrm{Ca}$ vs. temperature calibration of Bolton et al. (2011), comparable to a modern mean annual temperature of $19.34^{\circ} \mathrm{C} \quad(\mathrm{CARS}$, http://www.marine.csiro.au/ dunn/cars2009/) and temperatures of $\sim 20^{\circ} \mathrm{C}$ from RFM analysis from MIS 7c (Results section). Bolton et al. (2011) determined a calibration model for $\mathrm{Mg} / \mathrm{Ca}$ ratio (in $\mathrm{mmol} / \mathrm{mol}$ ) versus temperature $(\mathrm{T})$ of the form

$$
\mathrm{Mg} / \mathrm{Ca}=\mathrm{B} \mathrm{e}^{\mathrm{AT}}
$$

temperatures could be forecast by inverting (1):

$$
\mathrm{T}=(1 / \mathrm{A})(\log \mathrm{Mg} / \mathrm{Ca}-\log \mathrm{B})
$$

However, such inversions have been shown by Redmayne et al. (2012) to produce biased estimates when values of the forecasting variable, here $\mathrm{Mg} / \mathrm{Ca}$, have large scatter. Redmayne et al. (2012) provide a Bayesian method for overcoming this bias, which requires determining or assuming a prior distribution $p(T)$ (e.g. Congdon 2001, p15) for each depth sample of $G$. ruber. In practice the species will be confined to a finite temperature range, and we follow Marra et al. (2004) and use for the prior distribution a half-sine wave between limiting temperatures of $14^{\circ} \mathrm{C}$ and $30^{\circ} \mathrm{C}$. Forecasts are then obtained as medians of the posterior distribution for specimen temperature, $f(T \mid M g / C a)$

$$
f(T \mid M g / C a)=\frac{\operatorname{cal}(M g / C a \mid T) p(T)}{p(M g / C a)}
$$


where $\operatorname{cal}(\mathrm{Mg} / \mathrm{Ca} \mid T)$ is equation (1) and $p(M g / C a)$ is a prior distribution for $\mathrm{Mg} / \mathrm{Ca}$ ratios, which is not needed because the right hand side of equation (3) can be renormalized to make it a proper probability density function (Redmayne et al. 2012). This method provides 95\% confidence errors for the calculated temperature of each sample. Errors are shown as bars on Figure 7.16. Summary results are tabulated in Appendix 1.11, and complete profile data are in Appendix 3.

\subsection{SEM imaging P71 and ODP 1120}

Scanning Electron Microscope (SEM) imaging was carried out on the $<63 \mu \mathrm{m}$ grain size fraction of the sieved samples to determine the dominant species of coccolithophores, and the relative contribution of clay in the fine fraction. SEM images were taken using either a Jeol JSM-5300LV or a Jeol 6500F SEM. Carbon tape was attached to an SEM stub, with a silicon wafer placed on top. A pipette was used to place a drop of sediment diluted in MilliQ water onto a stub. Stubs were then dried under a heat lamp before being gold or platinum coated.

\subsection{Grain Size: P71 and ODP 1120}

Every second sample was analysed for grain size, with $0.3-0.5 \mathrm{~g}$ collected if the sample was muddy, and 0.5-1g collected if the sample was sandy. Samples were immersed in a $0.5 \mathrm{~g} / 1$ Calgon solution and agitated on a sieve shaker to disaggregate for 30 minutes. Some ODP 1120 samples were still found to contain aggregates after this time period and so an electronic stirrer was placed in the solution for a further 30 minutes. Samples were analysed on a Beckman Coulter LS13 320 laser diffraction particle size analyser for 60 seconds. There was a 300 second wash out after each sample, and laser alignment and background were measured before the next sample was added. Standards of $68 \mu \mathrm{m}$ glass beads were run at the start and end of each session to ensure the machine was consistent and accurate. These samples consistently had a mean within $1-2 \mu \mathrm{m}$ of $68 \mu \mathrm{m}$ and a standard deviation of $\sim 10 \mu \mathrm{m}$. Double 
runs of core samples were also done and were found to be consistently reproducible. Grain size data are tabulated in Appendix 1.6-1-7 and 2.4-2.5.

\subsection{Calcium carbonate content: P71}

Calcium carbonate $\left(\mathrm{CaCO}_{3}\right)$ content was determined using a vacuum gasometric procedure (Jones and Kaiteris, 1983). Approximately $\sim 0.6 \mathrm{~g}$ from every second sample down core was weighed and dried at $110^{\circ} \mathrm{C}$ for an hour, then crushed with a mortar and pestle. The sample was then dried for a further two hours at $110^{\circ} \mathrm{C}$ and cooled in a desiccator for an hour. Of the dried sample, $0.3 \mathrm{~g} \pm 0.05 \mathrm{~g}$ was weighed out and placed in $\mathrm{CaCO}_{3}$ reaction vessel. The reaction vessel number was recorded and five drops of distilled water added to the sediment to help control the reaction when the acid was introduced. $5 \mathrm{ml}$ of $70 \%$ orthoph osphoric acid was added to the side arm of the reaction vessel, ensuring no acid dropped on to the sediment. Silicon o-rings and the correctly numbered lids were placed and clamped on the reaction vessels.

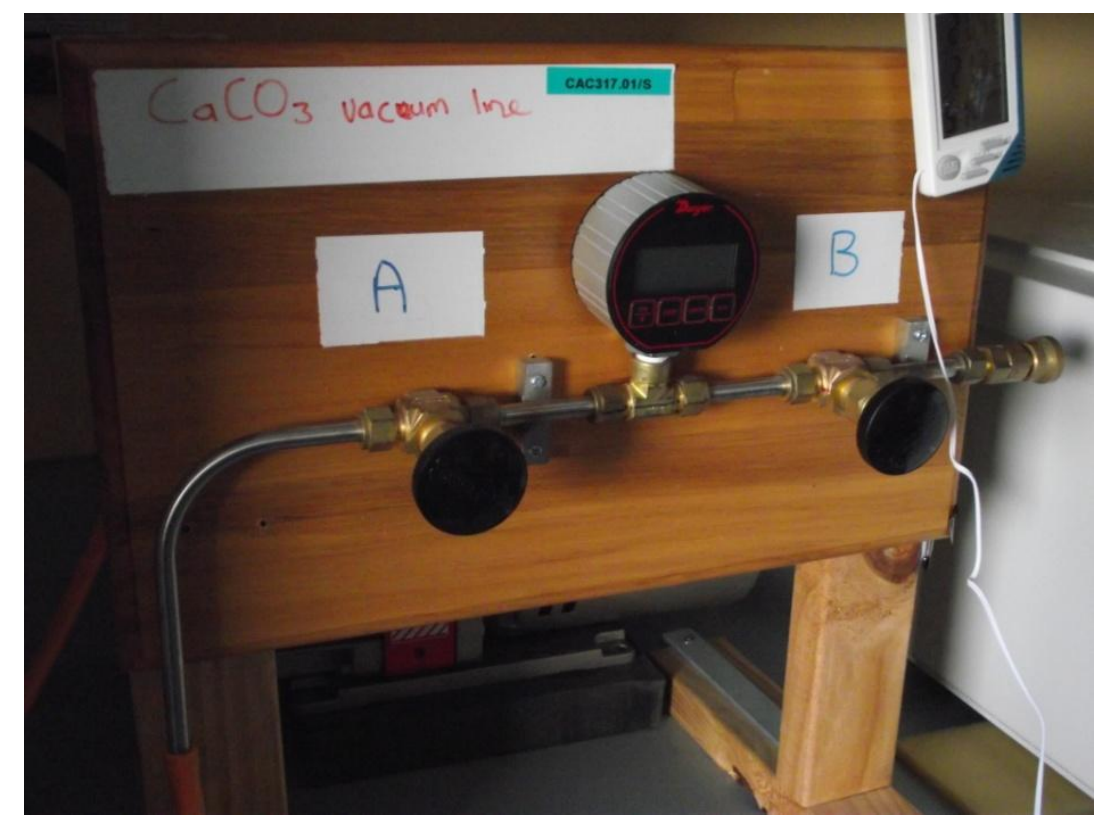

Figure 6.3. $\mathrm{CaCO}_{3}$ vacuum line showing the location of the $A$ and $B$ valves, and the pressure gauge (centre). The temperature gauge is at the top right of the picture. 
The air temperature was recorded and the digital pressure gauge set to zero. A reaction vessel was placed on the vacuum line with the vessel lid and the A and B valves of the vacuum line all opened (Fig. 6.3). Once the pressure was stabilised the start pressure was recorded, and the reaction vessel lid was closed and removed from the vacuum line. Once this process had been repeated for all the vessels, the vessels were tilted to introduce the acid to the sediment, and left to react for $1 \frac{1 / 2}{2}$ hours. A second temperature reading was also taken to be averaged with the first for a start temperature. Once the reaction vessels had reacted, a further temperature reading was taken and the vessel placed on the vacuum line. With the B valve remaining open the A valve was carefully opened to the start pressure value. The A valve was then closed, and the vessel lid opened to record the end pressure. The process was repeated with the rest of the reaction vessels, and a temperature reading was taken to get an end average temperature. The data were entered into an Excel macro to calculate the $\mathrm{CaCO}_{3}$ content of the samples. Standards of $100 \% \mathrm{CaCO}_{3}$ were analysed with every run and found to always be within 2\% of $100 \%$. Data can be found in Appendix 1.5. The vacuum gasometric procedure has an analytical error of $0.25 \%$ (Jones and Kaiteris, 1983).

This study was also given access to $\mathrm{CaCO}_{3}$ data for ODP 1120 that had been previously analysed at NIWA (Wellington). The first $300 \mathrm{~cm}$ of this record was published by Neil et al. (2004). Data from $300 \mathrm{~cm}-466 \mathrm{~cm}$ is unpublished.

\subsection{Foraminifera census and temperatures: $P 71$}

Foraminiferal census counts were carried out by Ashwaq T. Sabaa at Geomarine Research Ltd, Auckland. The census data were converted into temperatures using a Random Forest model (RFM) run by Dr. George Scott, GNS Science. Random Forest is a classification/regression method that uses an ensemble of decision trees with randomly chosen variables, and takes averages to reduce variation (Breiman, 2001, G. Cortese and G. 
Scott, GNS Science, pers. comm.). It is based on a data set of modern foraminifera assemblages of 1223 Southern Hemisphere core tops (G. Cortese and G. Scott, GNS Science, pers. comm.). Random Forrest can manage a large amount of data, and is able to estimate the relative importance of different variables, in this case foraminifera species, to determine the best possible temperature fit for the input of assemblage data. Errors were not assessed as part of this thesis; however the accuracy of RFM is comparable or better than artificial neural network analysis, modern analogue techniques and transfer functions (G. Cortese and G. Scott, GNS Science, pers. comm.) (Fig. 6.4). Assemblage data and temperatures are tabulated in Appendix 1.8, 1.9 and 1.10.

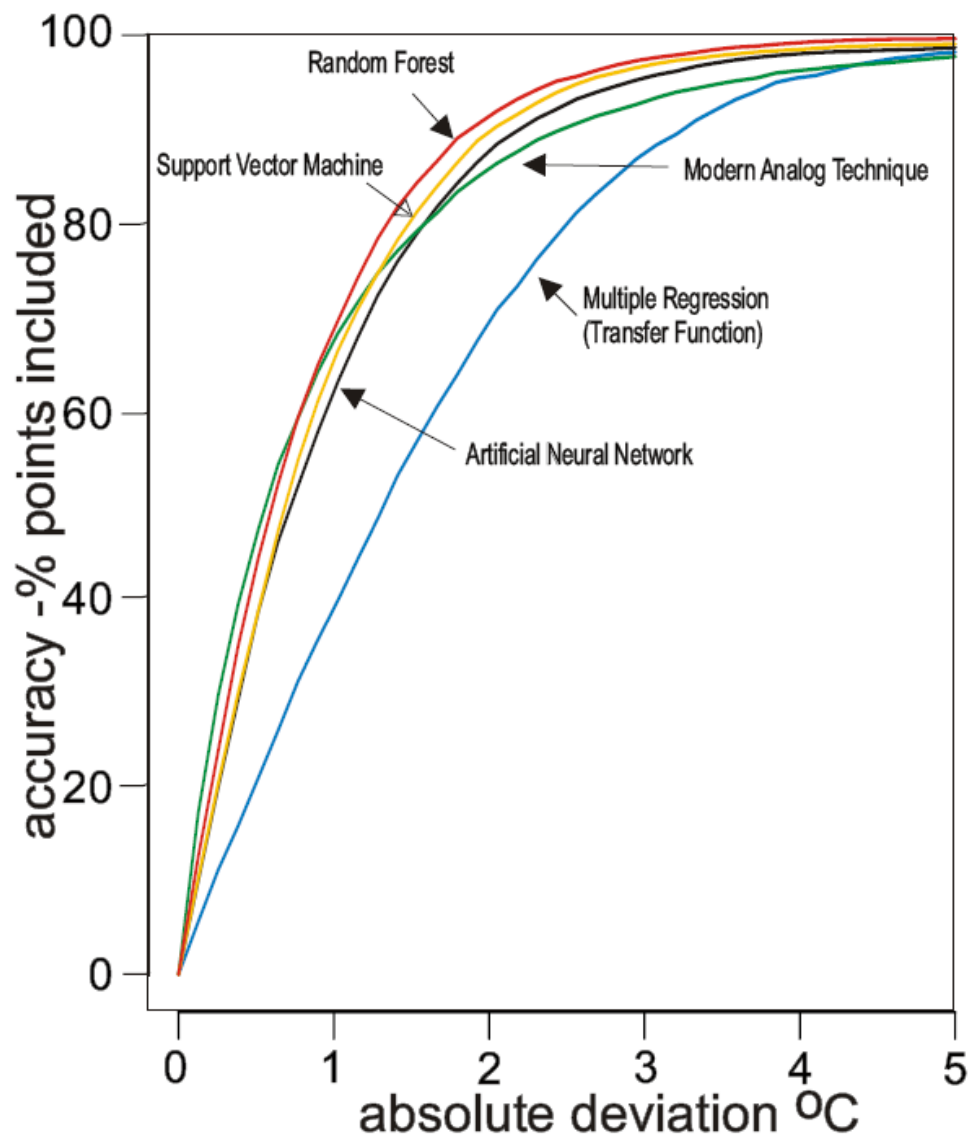

Figure 6.4: Accuracy of Random Forest Model compared to other temperature estimation models, diagram courtesy of Giuseppe Cortese. 


\section{RESULTS}

\subsection{Development of an age model for P71 and ODP 1120.}

Age models for P71 and ODP 1120 were developed using AnalySeries software (Paillard et al., 1996). This program enabled the $\delta^{18} \mathrm{O}$ records from Uvigerina spp. in each core to be interpolated using a series of tie points to the global benthic $\delta^{18} \mathrm{O}$ stack (Lisiecki and Raymo, 2005). The LR04 stack consists of 38,000 measurements from 57 core sites over a $5.3 \mathrm{Myr}$ record. Because it incorporates information from so many different sites, it is considered to accurately reflect changes in global climate (Lisiecki and Raymo, 2005). $\delta^{18} \mathrm{O}$ values are a function of global ice volume, temperature and salinity. Due to the global nature of the ice volume signal, $\delta^{18} \mathrm{O}$ measurements can be used to correlate a core to a common timescale (Lisiecki and Raymo, 2005). Benthic foraminifera are particularly useful in this regard as the deep-water stable isotope signal is less influenced by changes in temperature and salinity when compared with surface waters (Lisiecki and Raymo, 2005). P71 was correlated to the LR04 stack using 14 tie points, and ODP 1120 was correlated using 12 tie points (Fig. 7.1). Tie points were chosen where there was a significant change in $\delta^{18} \mathrm{O}$ values, such as transitions from glacials to interglacials, and between stadials and interstadials. 


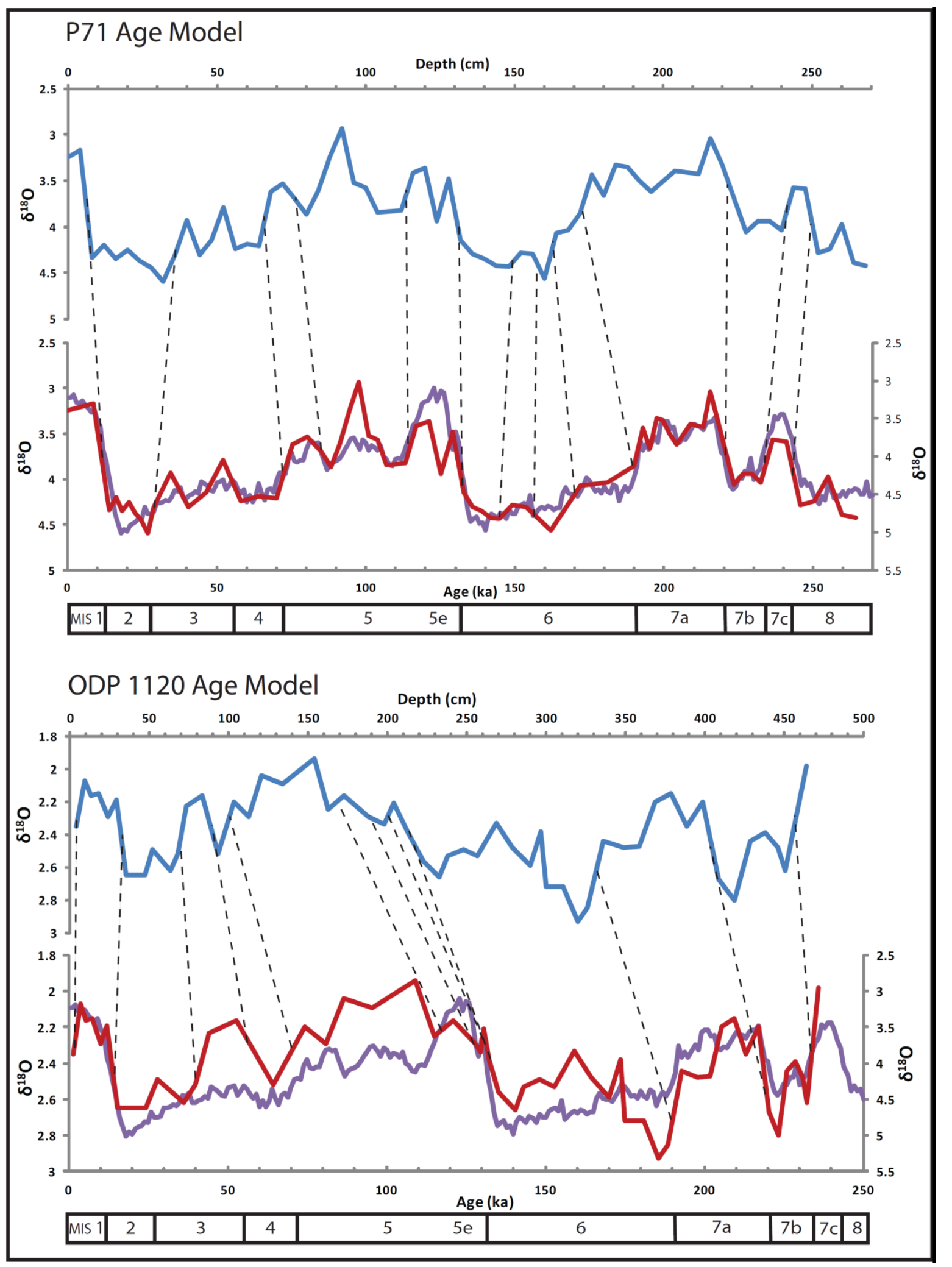

Figure 7.1: Age models for P71 and ODP 1120. Dashed lines represent tie points between benthic records from each core and LRO4 (purple line). 


\section{2. $\mathrm{CaCO}_{3}$}

Carbonate content in marine sediment is a function of biogenic carbonate production in relation to non-carbonate biogenic production, delivery of terrigenous sediment, and dissolution on the way to, and at, the sea bed (Hodell et al., 2001). Dissolution is not considered a significant factor at P71 or ODP 1120 as the calcite saturation zone below which dissolution predominantly occurs is at $2800 \mathrm{~m}$ northeast of New Zealand and $3130 \mathrm{~m}$ in the southeast (Bostock et al., 2011), considerably deeper than either core site. This is confirmed by a lack of visual evidence of dissolution in foraminiferal tests, and comparison with proximal fragmentation data (Bostock et al., 2011). Fragmentation indexes for the core also average $\sim 2.5$ (Appendix 1.8), indicating that only $2.5 \%$ of planktic tests have partially dissolved into chambers (Le and Shackleton, 1992). $\mathrm{CaCO}_{3}$ is consistently high at both core sites, averaging between 70-80\% for P71 and 85-95\% for ODP 1120 (Fig. 7.2). P71 has a pattern of higher $\mathrm{CaCO}_{3}$ in glacials, and lower $\mathrm{CaCO}_{3}$ in interglacials, while ODP 1120 has a less distinct pattern but appears high during interglacials with the exception of MIS 7. Commonly marine cores around $\mathrm{New}$ Zealand have lower glacial $\mathrm{CaCO}_{3}$ indicative of increased terrigenous input (Carter et al., 2000). ODP 1120 and P71 both differ from this showing that there is little input from terrigenous material at these core sites.

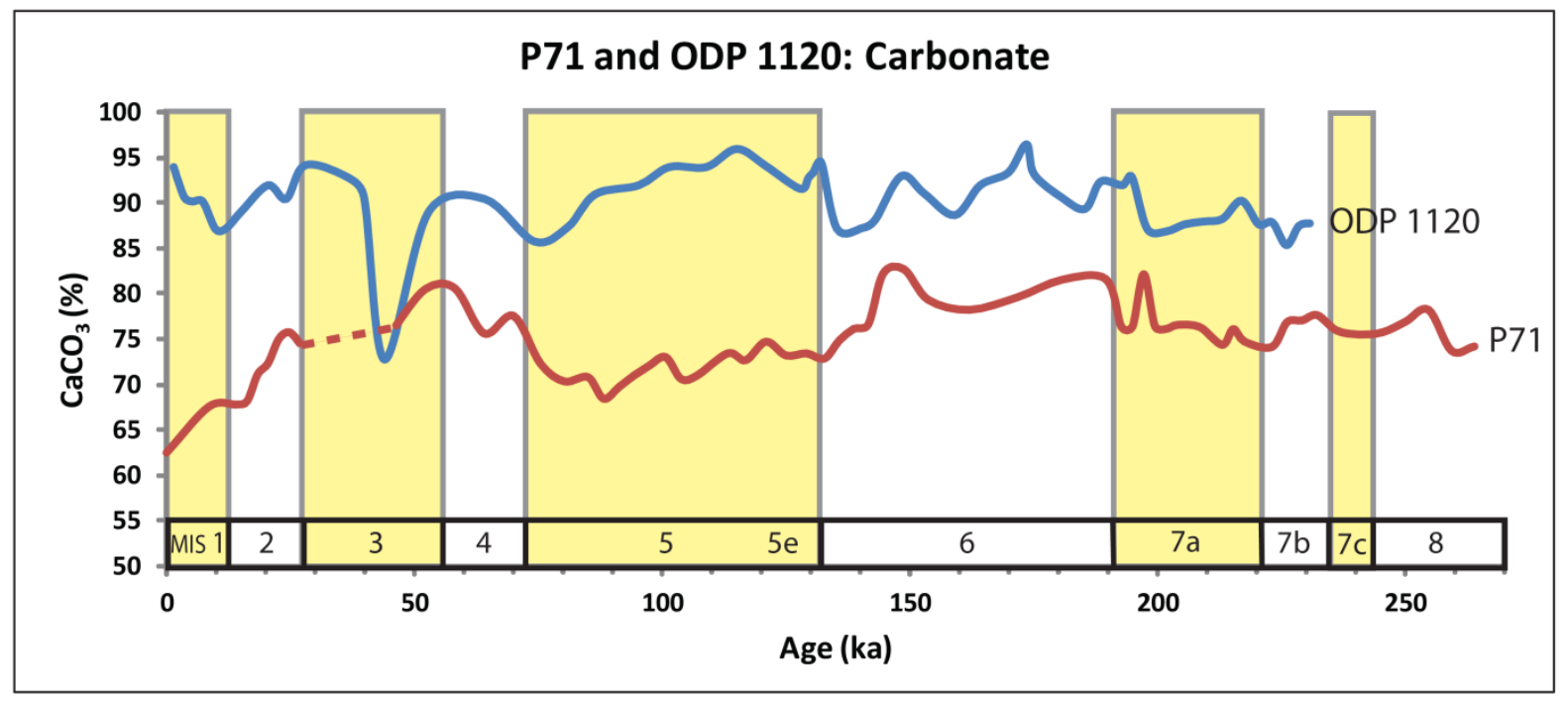


Figure 7.2: Calcium carbonate percentages down core for P71 and ODP 1120. The dashed line represents samples where $\mathrm{CaCO}_{3}$ values were not measured.

\subsection{Sedimentation and Mass Accumulation rates}

The sedimentation rate of P71 varied between 0.4 and $1.9 \mathrm{~cm} / \mathrm{kyr}$ (Fig. 7.3). It was highest during interglacials, with the exception of MIS 1, where the highest rates of $1.9 \mathrm{~cm} / \mathrm{kyr}$ occured during MIS 2, from 27-14ka. It is possible that the MIS 1 sedimentation rates could be affected by loss of material, or mixing of the surface layer, when the core was cored. The next highest sedimentation rates of $1.8 \mathrm{~cm} / \mathrm{kyr}$ occurred during MIS 7a, from 215-193ka. The lowest sedimentation rates of $0.45 \mathrm{~cm} / \mathrm{kyr}$ were during MIS 1 and MIS 6 . The overall sedimentation rate of ODP 1120 (Fig 7.4) was higher than P71, varying between 1 and 3.5 $\mathrm{cm} / \mathrm{kyr}$, with the exception of MIS $5 \mathrm{e}$ where a peak of $6 \mathrm{~cm} / \mathrm{kyr}$ was observed. The age model through MIS 5e has been constrained to fit high benthic and planktic foraminiferal $\delta^{18} \mathrm{O}$ into MIS 6 and low benthic and planktic foraminiferal $\delta^{18} \mathrm{O}$ to MIS 5e. This has resulted in a high sedimentation rate during this time period. The high sedimentation rate is not necessarily an artefact of the age model, however, as the grain size data (Section 7.4) shows a significant peak in fine sediment throughout MIS 5e, possibly suggesting an enhanced flux of coccolithophores to the sea floor, which would have resulted in an increased sedimentation rate. While this sedimentation rate does seem unusually high, this age model is considered to be the best reconciliation of the available $\delta^{18} \mathrm{O}$ data. 


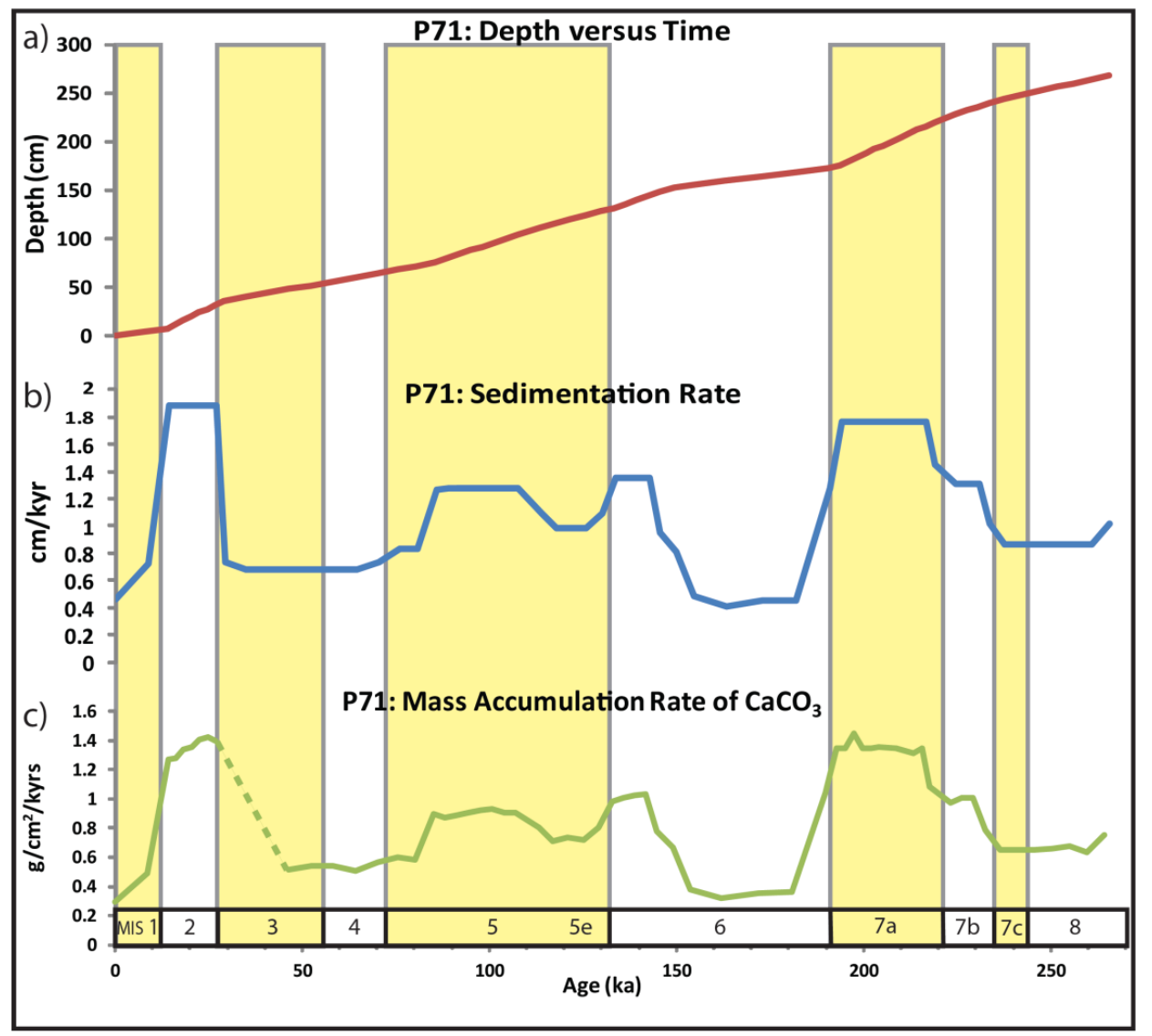

Figure 7.3: Depth versus time, sedimentation rate and mass accumulation rate of $\mathrm{CaCO}_{3}$ for P71. The dashed line in MAR represents samples where the $\mathrm{CaCO}_{3}$ values were not measured.

The mass accumulation rate (MAR) of carbonate can be used as an approximate paleoproductivity indicator, due to the positive correlation between carbonate production and organic carbon production (Brummer and van Eijden, 1992). This assumes little loss of carbonate via erosion or dissolution. The MAR of carbonate describes the mass flux of carbonate to the seafloor (Brummer and van Eijden, 1992) and can be described by the equation:

MAR $\mathrm{CaCO}_{3}=\left(\mathrm{wt} \% \mathrm{CaCO}_{3} / 100\right) \times \mathrm{LSR} \times \mathrm{DBD}$ 
Where LSR is the linear sedimentation rate and DBD is the dry bulk density. While DBD data are not published for core ODP $1120 \mathrm{C}$ used in this study, values have been published for ODP 1120B and 1120D, and averages $1 \mathrm{~g} / \mathrm{cm}^{3}$ (Carter et al., 1999). This value has been used for the DBD for ODP 1120 and P71, in the absence of data for the latter core. A value of 1 $\mathrm{g} / \mathrm{cm}^{3}$ for P71 is considered robust as it is consistent with Carter et al. (2000), who derived a relationship between $\mathrm{CaCO}_{3}$ and $\mathrm{DBD}$ to determine the $\mathrm{DBD}$ of dry cores. The $\mathrm{CaCO}_{3} \mathrm{MAR}$ is comparable to the sedimentation rate for both cores, with highest MARs occurring in interglacials and transitions from glacials to interglacials. P71 had the highest MARs in MIS 7a and MIS 1/2 transition of 1.3-1.4 g/ $\mathrm{cm}^{2} / \mathrm{kyr}$, and lowest during MIS 1 and MIS 6 of 0.3$0.4 \mathrm{~g} / \mathrm{cm}^{2} / \mathrm{kyr}$. ODP 1120 had highest MARs at MIS 5e, reaching $6 \mathrm{~g} / \mathrm{cm}^{2} / \mathrm{kyr}$, and lowest during MIS 3 of $\sim 1 \mathrm{~g} / \mathrm{cm}^{2} / \mathrm{kyr}$.

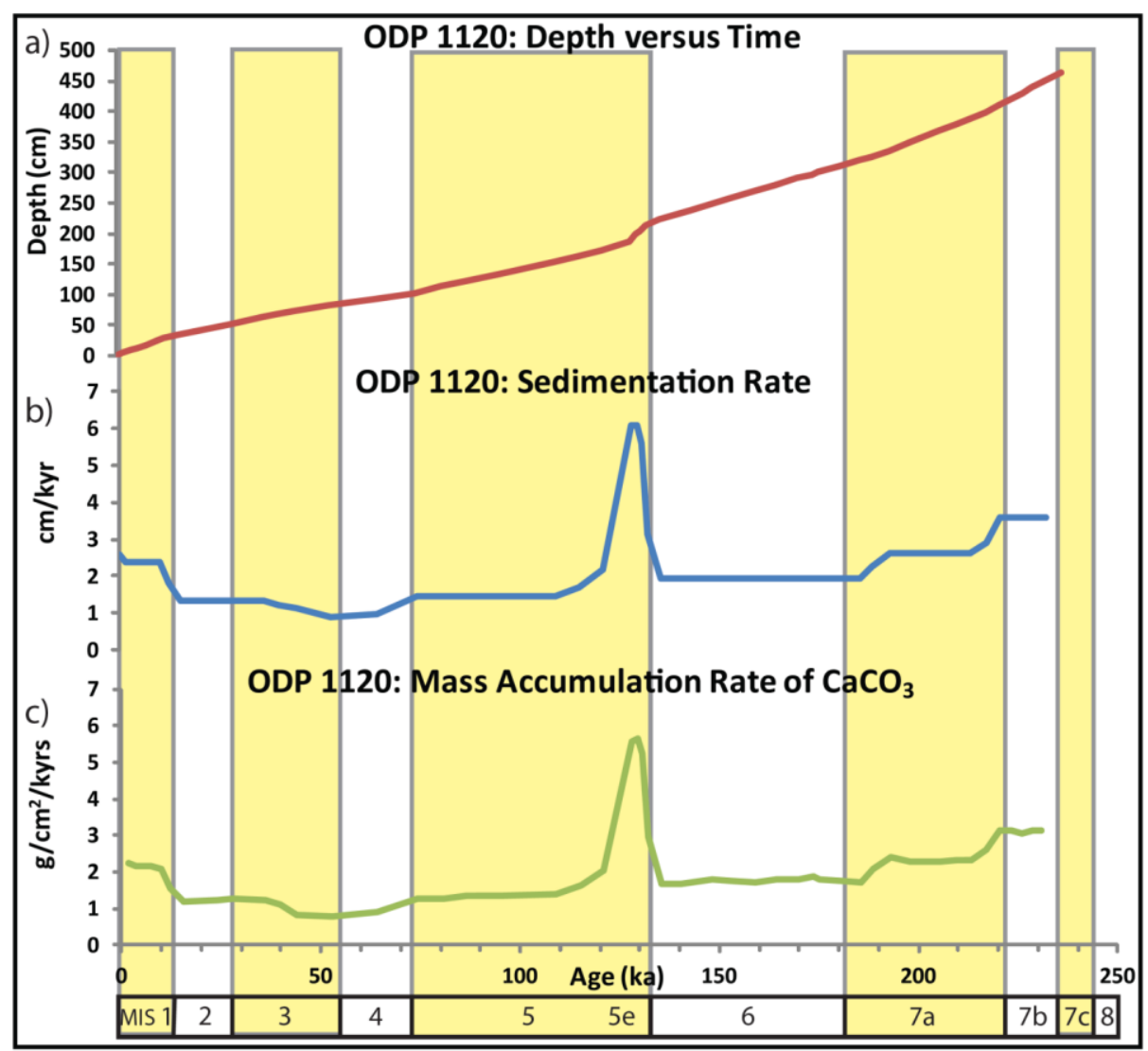

Figure 7.4: Depth versus time, sedimentation rate and mass accumulation rate of $\mathrm{CaCO}_{3}$ for ODP 1120. 
The MAR of the $<20 \mu \mathrm{m}$ fraction is shown in Figure 7.5. The MAR $<20 \mu \mathrm{m}$ can be described by the equation:

$$
\text { MAR }<20 \mu \mathrm{m}=(\%<20 \mu \mathrm{m} / 100) \times \mathrm{LSR} \times \mathrm{DBD}
$$

Where $<20 \mu \mathrm{m}$ is determined from grain size data (section 7.4). High MAR in the $<20 \mu \mathrm{m}$ fraction coincides with high sedimentation rates and $\mathrm{MAR} \mathrm{CaCO}_{3}$ in both $\mathrm{P} 71$ and ODP 1120. For example high values occur during MIS 5e in ODP 1120 , and MIS 1/2, 5d and 7a in P71.

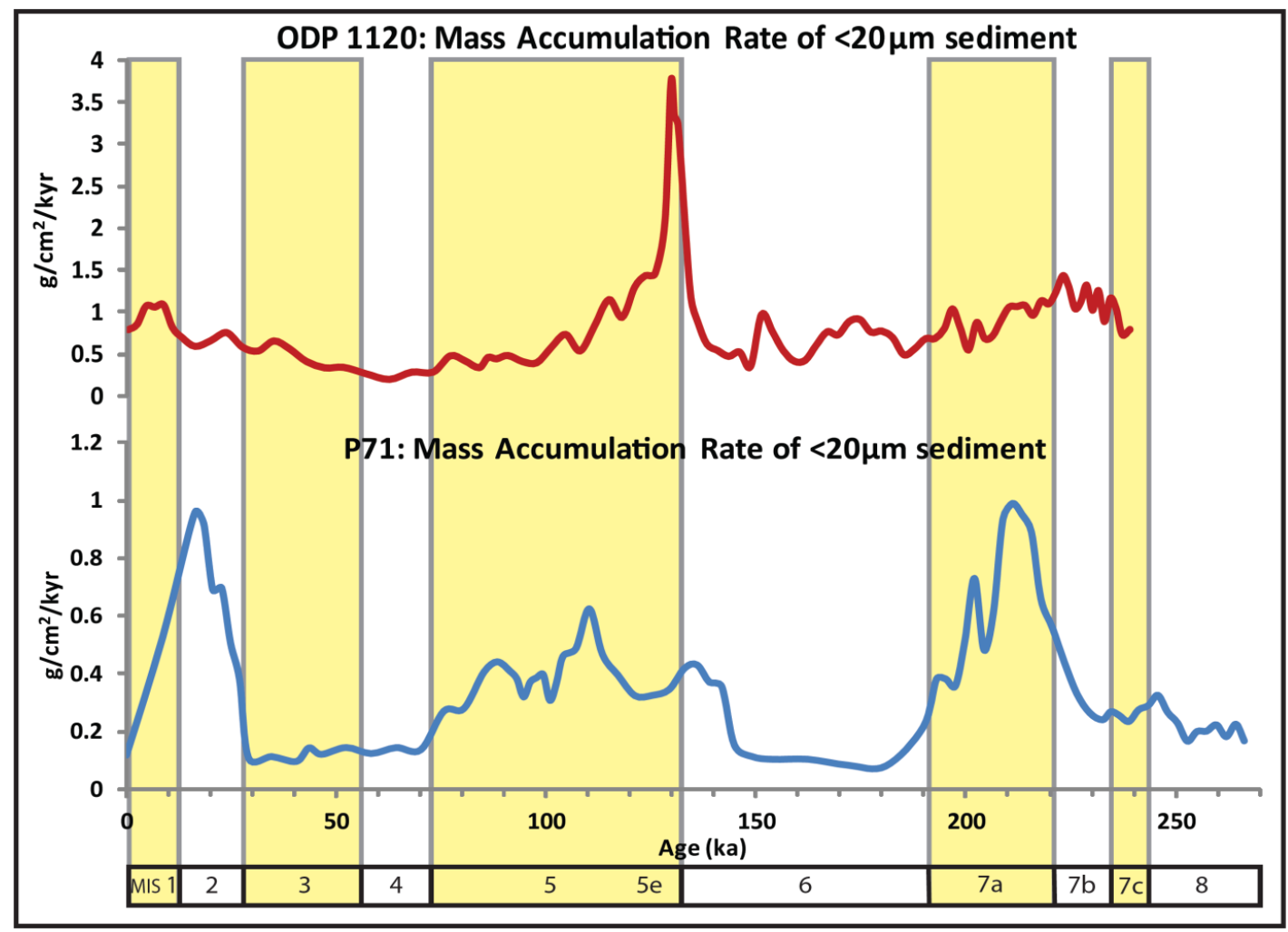

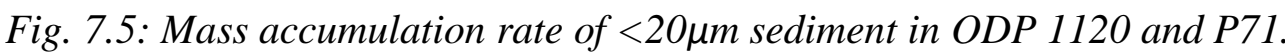

\subsection{Grain size}

Grain size distributions in individual samples generally show two prominent modes, a coarse foraminifera-dominant mode and a fine coccolith-dominant mode (Fig. 7.6). The coarse mode peaks between $90-200 \mu \mathrm{m}$ in P71 and ODP 1120 . The fine mode in P71 peaks between 2- 
$10 \mu \mathrm{m}$, while in ODP 1120 commonly has two modes in the fine fraction, one at $2 \mu \mathrm{m}$ and the other at $8-10 \mu \mathrm{m}$ (fig. 7.6 ). In the coarse mode, ODP 1120 has very little material $>300 \mu \mathrm{m}$, while P71 has a broader coarse mode with some material reaching 700-800 $\mu \mathrm{m}$.

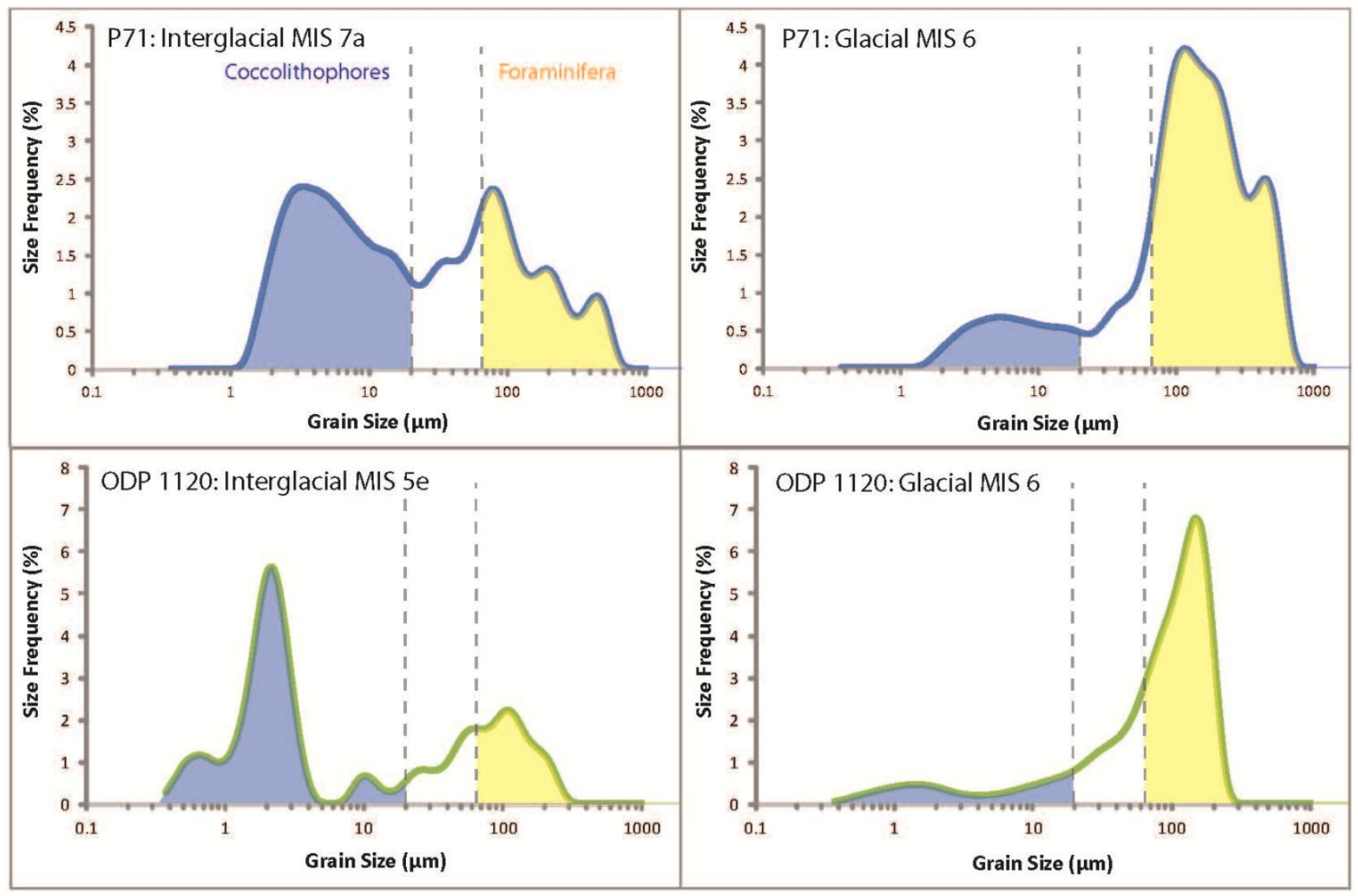

Figure 7.6: Grain size distributions for MIS 7a and MIS 6 at P71, and MIS 5e and MIS 6 at ODP 1120. Blue areas represent grain size frequencies in the coccolith size range, yellow areas represent grain size frequencies in the foraminifera size range.

In P71 sediments are generally coarser in glacial periods and finer in interglacials (Fig. 7.7). However, it also appears that late glacial and glacial/interglacial transitions also contain a larger amount of fine material, particularly the MIS1/2 transition. The largest peak of fine material in MIS $7 \mathrm{a}$ is between $209-218 \mathrm{ka}$ reaching $56 \%<20 \mu \mathrm{m}$ grains at $211 \mathrm{ka}$. Other significant peaks occur at 110ka and 16ka, with fine grain sizes of $49 \%$ and $51 \%$, respectively. The core top sample did not disaggregate fully, biasing it towards the coarser end of the scale as much of the fine material adhered to coarser particles. 
ODP 1120 has a less consistent pattern, with fine peaks occurring in both glacial and interglacials, as well as during transitions (Fig. 7.7). The most prominent fine peak occurs at MIS 5e-5d, and reaches values of 66-68\% from $125-122 \mathrm{ka}$, and a peak of $72 \%$ at $114 \mathrm{ka}$. This is significantly higher than at any other point in the core with the next highest value occurring at $24 \mathrm{ka}$ with $57 \%$. MIS $7 \mathrm{a}$ only reaches values of $\sim 40 \%$ from $220-208 \mathrm{ka}$, the period that coincides with the peak in fine material at P71.

Many studies deal with the distribution of species of coccolithophores and foraminifera over time, but few deal with their relative proportions in sediment (Broecker and Clark, 2009). While changes from foraminifera-rich to coccolithophores-rich horizons have been noted in shipboard logs of sediment cores (Carter et al., 1999), little research has been done to evaluate these changes quantitatively. Frenz et al. (2005) proposed that relative proportions of coccolithophores and foraminifera could be determined by grain size analysis, with the boundary between coccolithophores and foraminifera at $8 \mu \mathrm{m}$; however, they also state that using $20 \mu \mathrm{m}$ as the size division was also accurate. This is supported by Broecker and Clark (2009) who found that foraminifera fragments are not usually smaller than $20 \mu \mathrm{m}$. Their electron microscope images of the $<20 \mu \mathrm{m}$ fraction from Holocene sediment on the Ontong Java Plateau showed that the $\mathrm{CaCO}_{3}$ was all derived from coccolithophores.

While the cores contain a small amount of non-carbonate material $(20-30 \%$ for P71; 5-15\% for ODP 1120), using laser grain size analysis to interpret the relative abundance of foraminifera and coccolithophores is still considered a robust method for two reasons. First SEM imaging (Section 7.5) shows that the majority of the fine fraction consists of coccoliths, with clay as a minor component. Secondly, there is little change in carbonate content down core. The locations of both cores are distant from major fluvial sources. This suggests that terrigenous material is likely to be aeolian derived or suspended in currents. Neil et al. (2004) found that the non-carbonate flux in the interior of the Campbell Plateau did not vary 
significantly between MIS 1 and MIS 2. Some biosiliceous material is present, particularly in ODP 1120, where SEM images show the presence of diatoms (Fig. 7.13). Theide et al (1997) suggest that biosilica only makes up $<3.35 \%$ of the non carbonate fraction in cores on the Chatham Rise and in the Bounty Trough. As the size and amount of the terrigenous component changes little down core, the grain size variations reflect those of the dominant carbonate component, i.e. the relative contributions of foraminifera to coccolithophores.

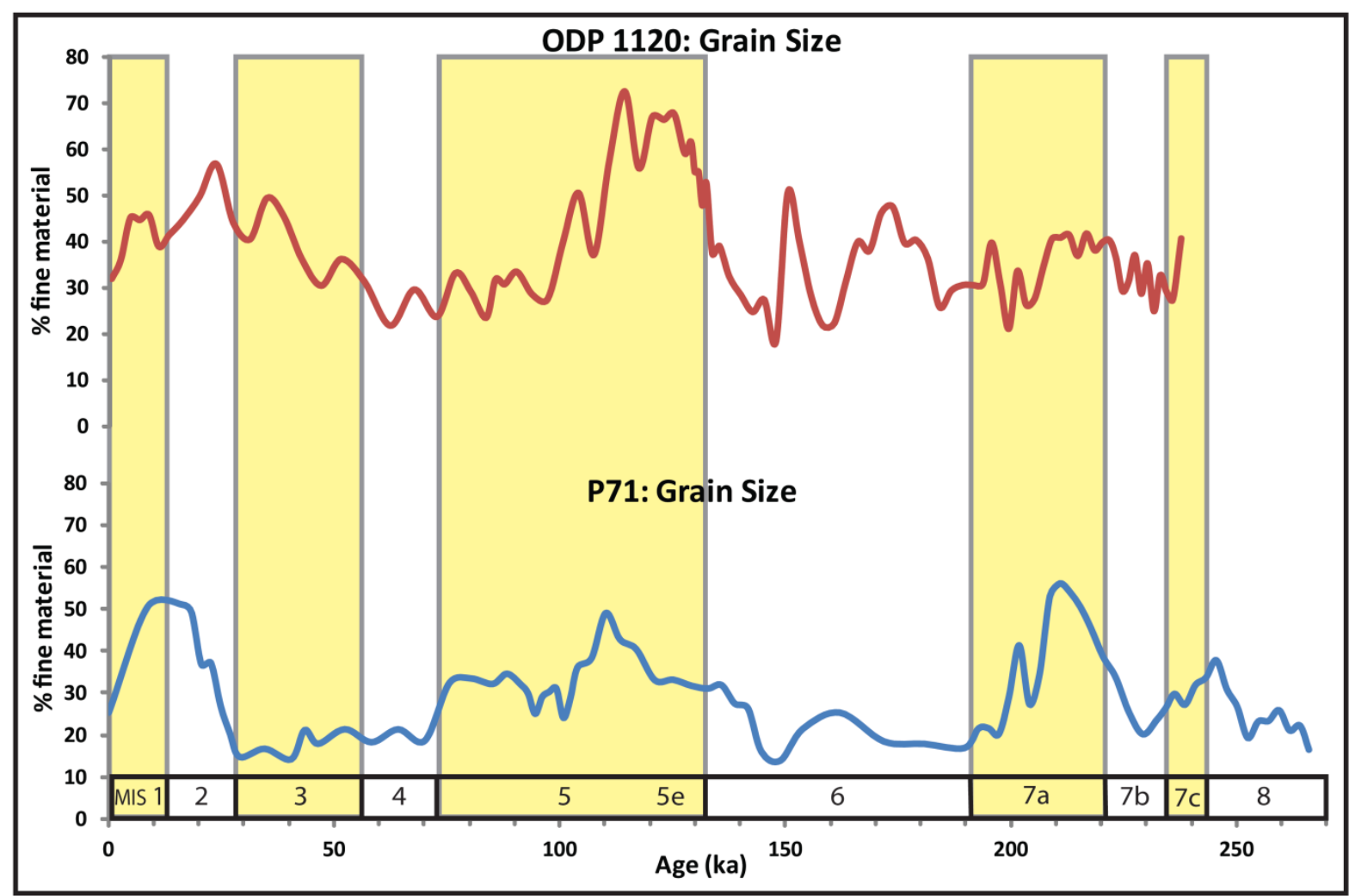

Figure 7.7: Percentage of fine grained $(<20 \mu \mathrm{m})$ material in ODP 1120 and P71.

\subsection{Coccolith species composition}

SEM images of the $<63 \mu \mathrm{m}$ sieved fraction of P71 were taken on samples with ages of 11.414.1ka, 22.6-24.8ka and 209.8ka. SEM images of the $<63 \mu \mathrm{m}$ sieved fraction of ODP 1120 were taken on samples of $0.4-1.4 \mathrm{ka}, 128.4 \mathrm{ka}$ and $212 \mathrm{ka}$. SEM images were analysed qualitatively using visual estimates for the dominant species in each sample, and the relative 
proportion of clay to coccoliths. All samples were predominantly coccoliths and coccolith fragments, with clay forming a minor component (Figs. 7.8-7.13 a.).

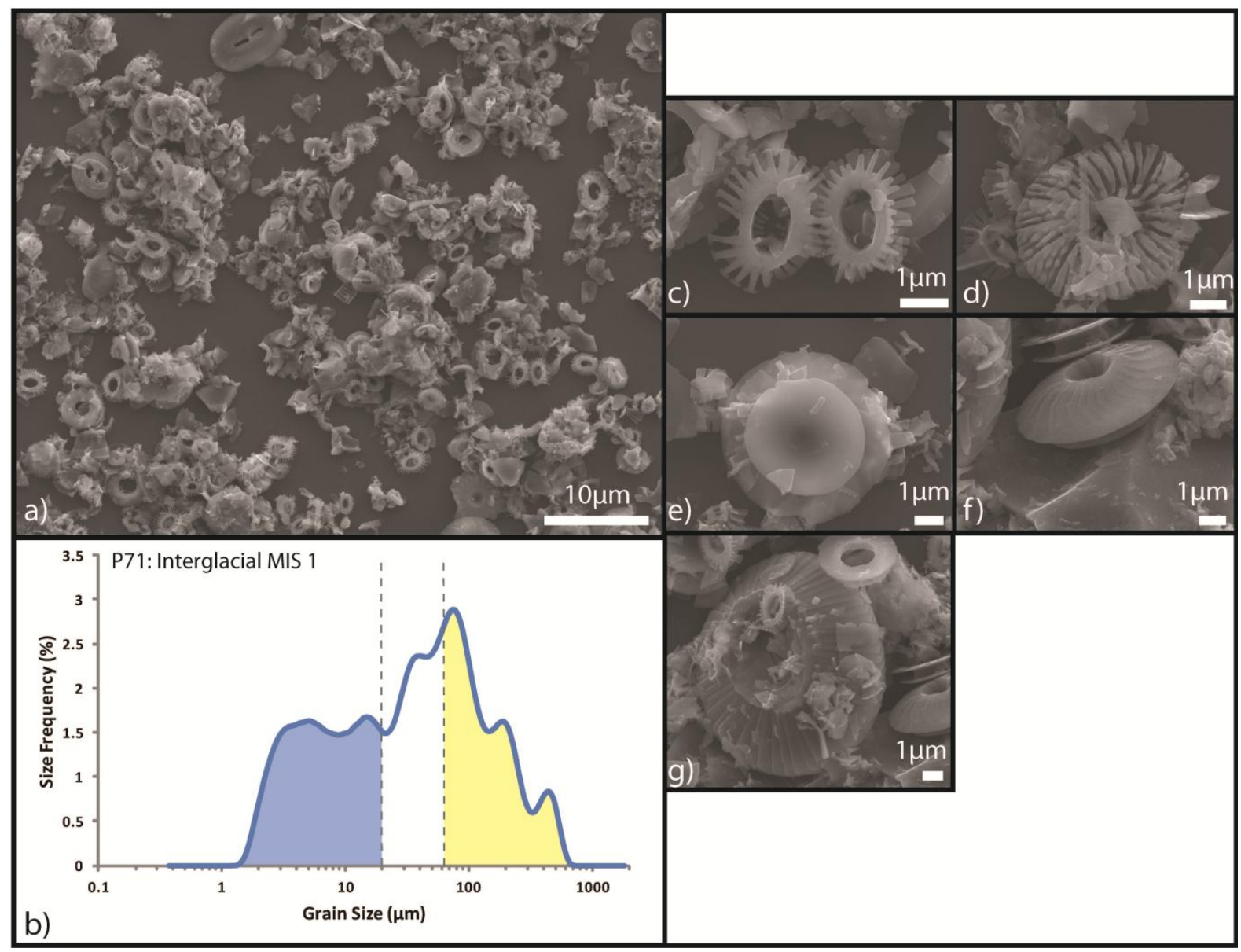

Figure 7.8: SEM images from 11.4-14.1 ka in P71. A) Overview of $<63 \mu \mathrm{m}$ material, b) grain size distribution of the whole sample, c) coccoliths from Emiliania huxleyi, d) Umbellosphaera tenuis, e) Oolithotus antillarum, f) Calcidiscus leptoporus, g) Coccolithus pelagicus.

Figure 7.8 shows the grain size distribution and dominant coccolith species for 11.4-14.1ka in P71, representing the end of the transition from MIS 2 to MIS 1. The grain size distribution (Fig. 7.8. b.) shows a large variation in coccolith sizes from $2-15 \mu \mathrm{m}$, but with very little $<2 \mu \mathrm{m}$. This is supported by the overview SEM image (Fig. 7.8. a.) which shows coccoliths from different coccolithophore species occupying a wide size range. The dominant species in this sample is E. huxleyi with Gephyrocapsa spp. also common, both sit within a $2-5 \mu \mathrm{m}$ size 
range. Other relatively common species are Helicosphaera carteri which can reach $>10 \mu \mathrm{m}$ diameter, Umbellosphaera tenuis, Oolithotus antillarum, Calcidiscus leptoporus, and Coccolithus pelagicus.

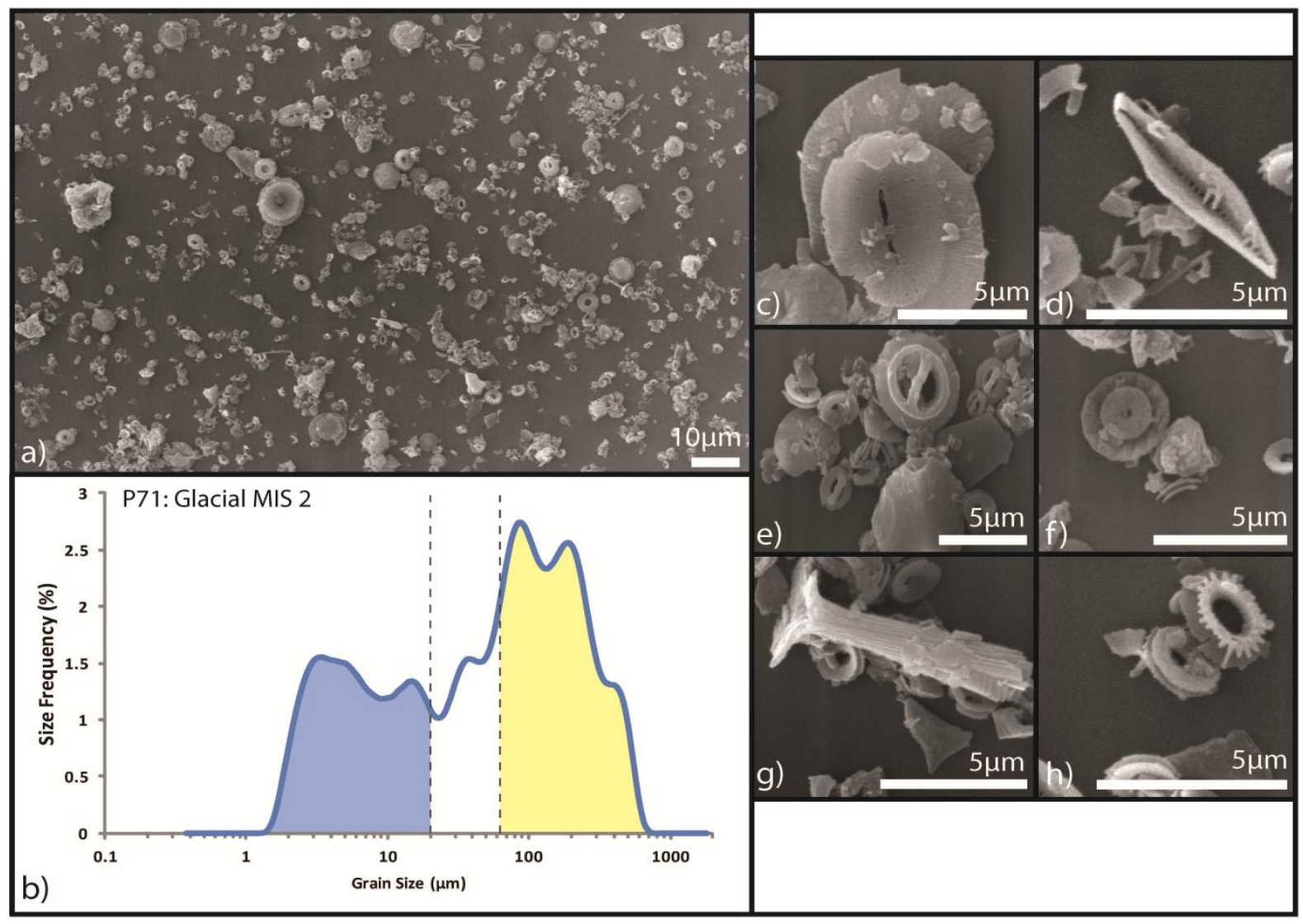

Figure 7.9. SEM images from 22.6-24.8ka in P71. A) Overview of $<63 \mu \mathrm{m}$ material, b)

grainsize distribution of the whole sample, c) Helicosphaera carteri, d) Calciosolenia fossilis, e) Gephyrocapsa muellerae, f) Oolithotus antillarum, g) Rhabdosphaera clavigera, h) Emiliania huxleyi.

Figure 7.9. presents the grain size distribution and dominant coccolith species for $22.6-24.8 \mathrm{ka}$ in P71, representing MIS 2. The grain size distribution (Fig. 7.9. b.) shows a large variation in coccolith sizes, but with smaller coccoliths more common during the MIS 1-2 transition (Fig. 7.8. b.). The overview SEM image (Fig. 7.9. a.) highlights large coccoliths $>10 \mu \mathrm{m}$ in size, together with smaller species in the $2-5 \mu \mathrm{m}$ size range. The dominant species in MIS 2 are Gephyrocapsa spp., predominantly G. muellerae, with E. huxleyi also common. Also present 
are Helicosphaera carteri, Calciosolenia fossilis, Oolithotus antillarum, Rhabdosphaera clavigera and Calcidiscus leptoporus.

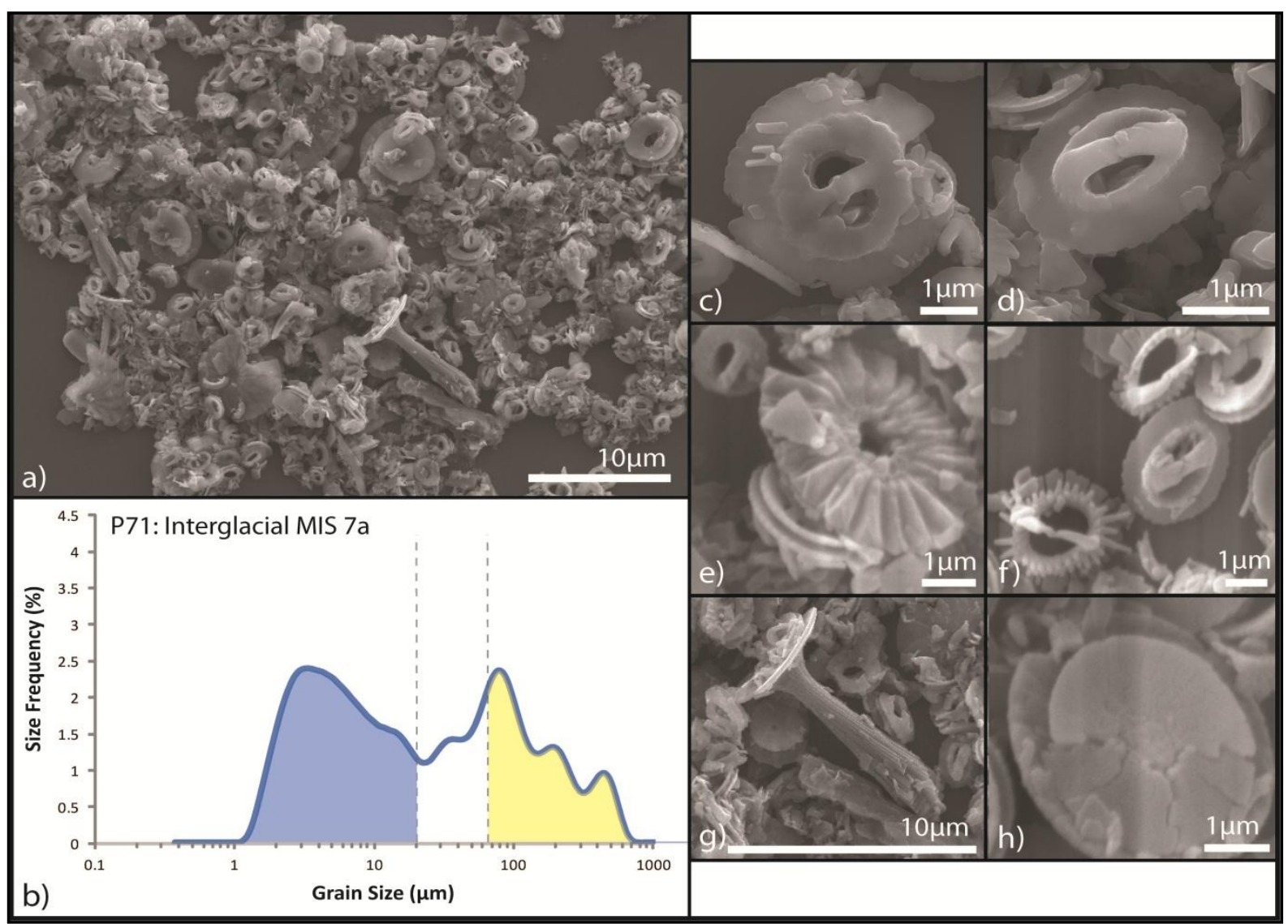

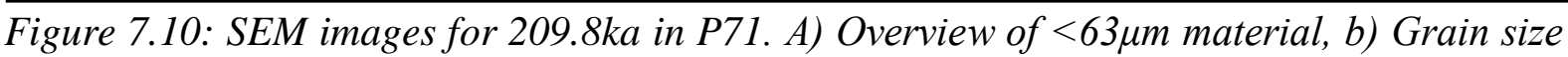
distributions of the whole sample, c) Gephyrocapsa oceanica, d) Gephyrocapsa aperta, e) Umbellosphaera tenuis, f) (center left) Gephyrocapsa aperta, (center right) Gephyrocapsa ornata, g) Rhabdosphaera clavigera, h) Oolithotus antillarum.

Figure 7.10 shows the grain size distribution and dominant coccolith species for $209.8 \mathrm{ka}$ in P71, representing the fine sediment peak at MIS 7a (Fig 7.7). The grain size distribution and overview SEM image (Figs 7.10. a) and b) show more small coccoliths than the younger two samples (Figs 7.8 and 7.9), with $2-4 \mu \mathrm{m}$ the most common range. This is due to the predominance of Gephyrocapsa spp. mainly G. oceanica and G. aperta. Other common species include G. ornata, Umbellosphaera tenuis, Rhabdosphaera clavigera, Oolithotus antillarum and Calcidiscus leptoporus. 


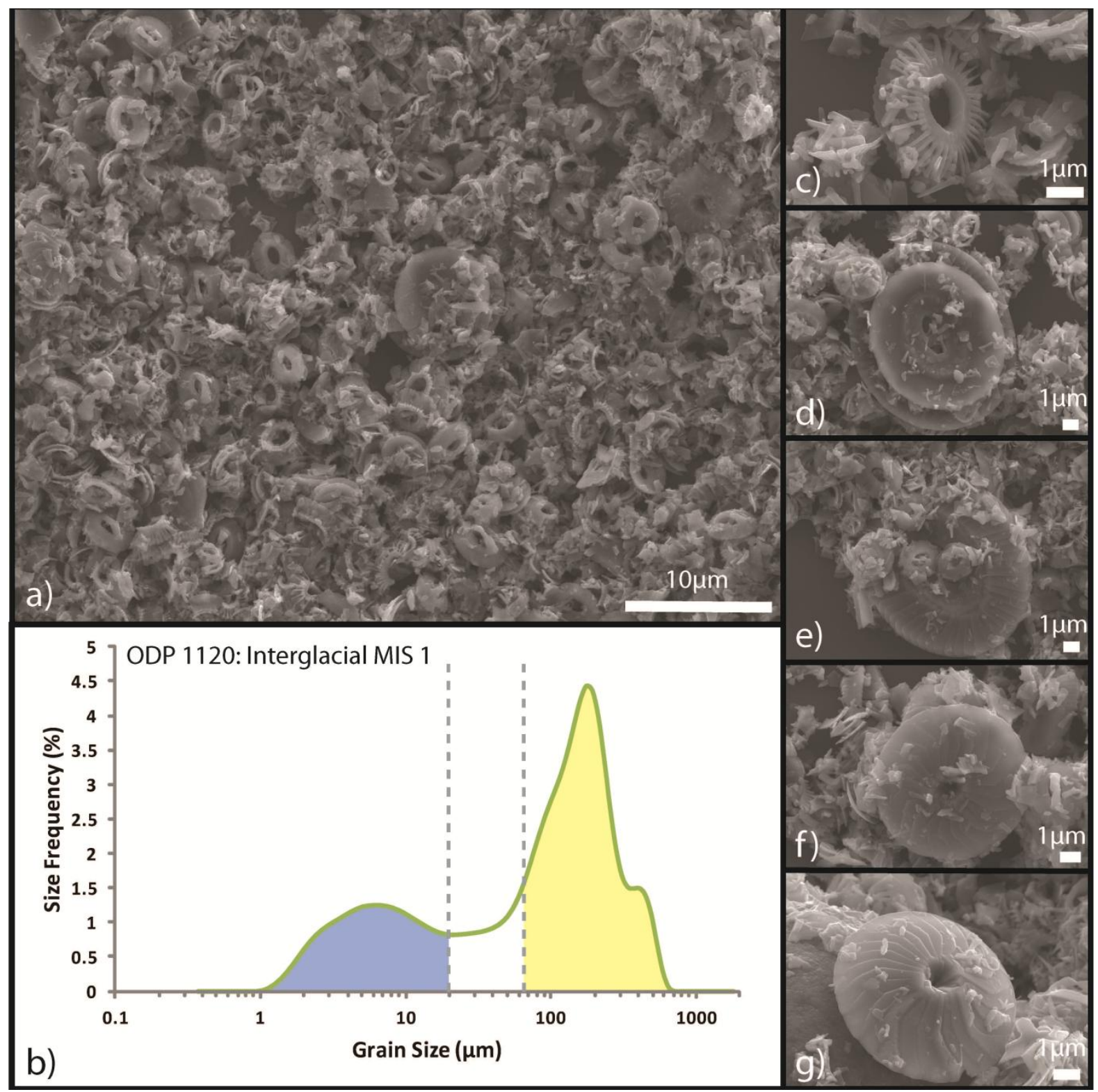

Figure 7.11: SEM images from 0.4-1.4ka in ODP 1120. A) Overview of <63 4 m material, b) grain size distribution of the whole sample, c) Emiliania huxleyi, d) Coccolithus pelagicus, e) Coccolithus pelagicus, f) Calcidiscus leptoporus, f) Calcidiscus leptoporus.

Figure 7.11 summarises the grain size distribution and dominant coccolith species for 0.41.4ka in ODP 1120. The grain size distribution (Fig. 7.11 b.) has a large variation in sizes with a broad peak at $5-8 \mu \mathrm{m}$. This is supported in the wide variation in coccolith sizes in the SEM overview image (Fig. 7.11 a).). Common smaller species $(2-5 \mu \mathrm{m})$ are E. huxleyi and Gephyrocapsa spp., mainly G. muellerae. Common larger species $(5-10 \mu \mathrm{m})$ are Coccolithus pelagicus and Calcidiscus leptoporus. 


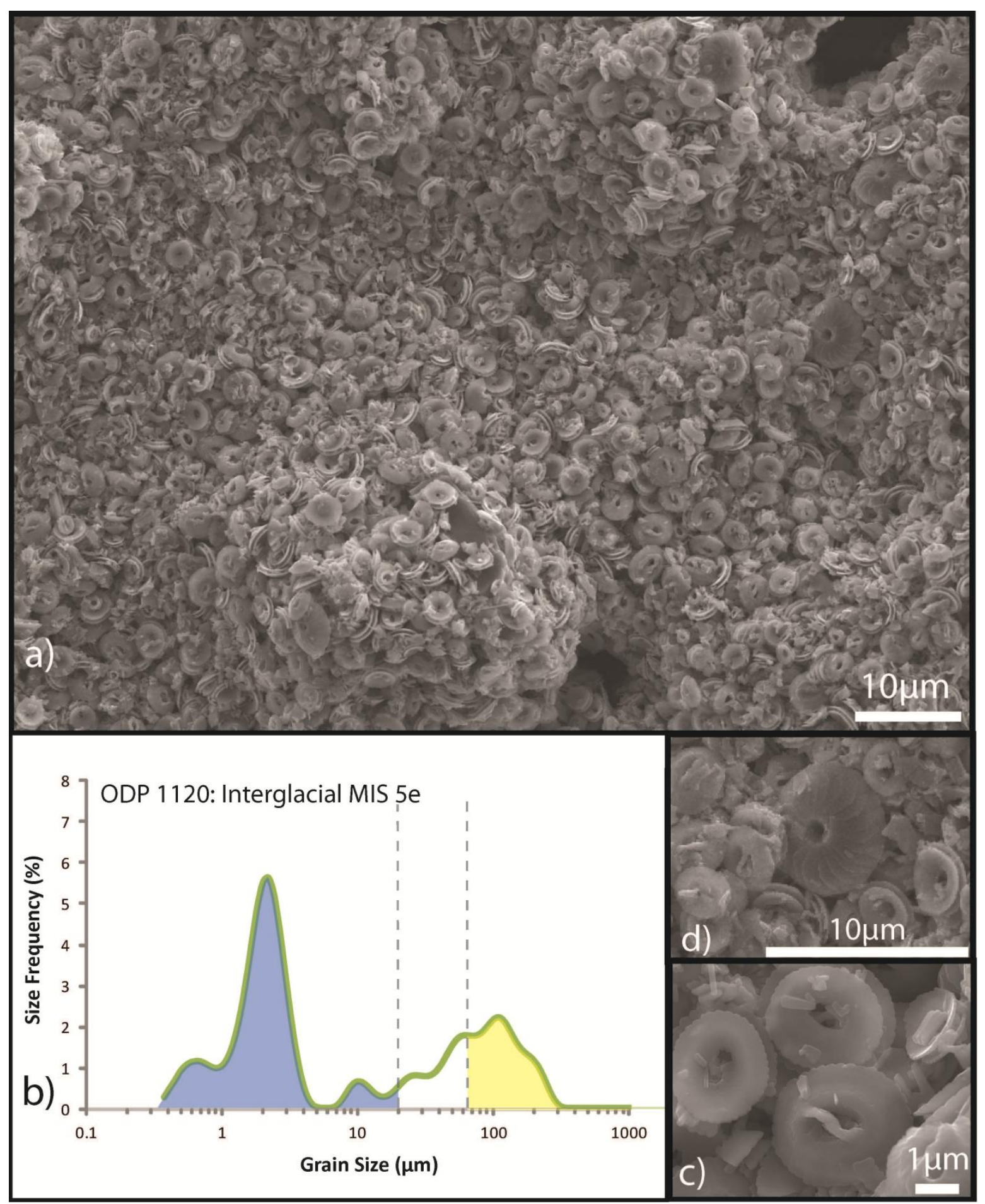

Figure 7.12: SEM images from 128.4ka in ODP 1120. A) Overview of $<63 \mu \mathrm{m}$ material, b)

grain size distribution of the whole sample, c) Gephyrocapsa caribbeanica, d) (centre)

Calcidiscus leptoporus.

Figure 7.12 shows the grain size distribution and dominant coccolith species for $128.4 \mathrm{ka}$ in ODP 1120, representing MIS 5e. The grain size distribution (Fig. 7.12. b.) reveals the 
coccoliths have a significant peak in frequency at $2 \mu \mathrm{m}$, with much smaller peaks at 0.5 $0.8 \mu \mathrm{m}$ and $8-10 \mu \mathrm{m}$. This is confirmed by the SEM images, which show the sample consists almost exclusively of Gephyrocapsa caribbeanica, with a size of $\sim 2 \mu \mathrm{m}$. The other finer size peak represents broken pieces of this species, while the larger peak reflects the only other identified species in this sample, Calcidiscus leptoporus.

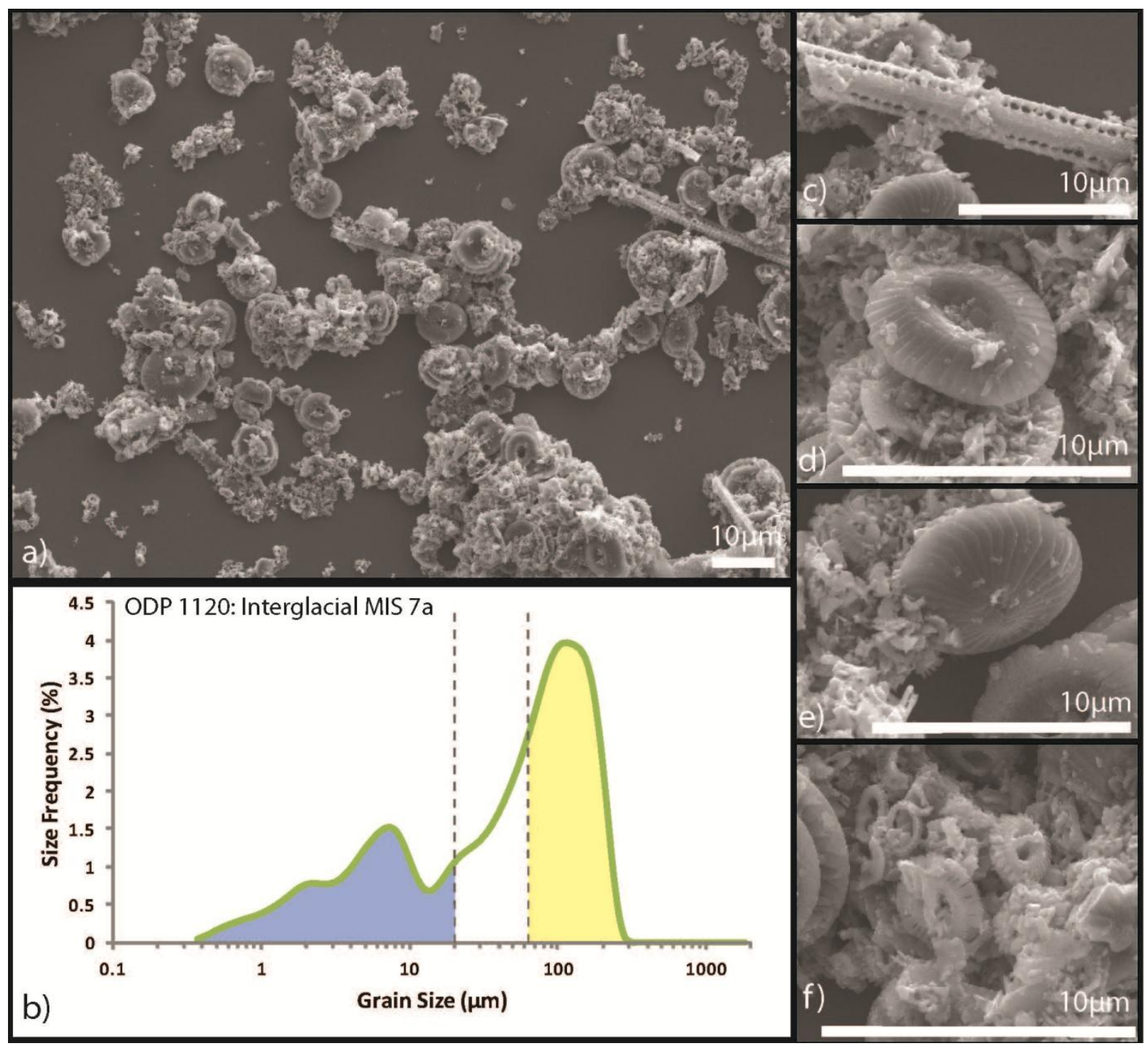

Figure 7.13: SEM images from 212ka in ODP 1120. A) overview of $<63 \mu \mathrm{m}$ material, b) Grain size distribution of whole sample, c) Diatom Thalassiothrix spp., d) Coccolithus pelagicus, e) Calcidiscus leptoporus, f) (centre) Gephyrocapsa protohuxleyi. 
Figure 7.13 shows the grain size distribution and dominant coccolith species for $212 \mathrm{ka}$ in ODP 1120 , representing MIS 7a. Two peaks are evident in the fine fraction, at $2 \mu \mathrm{m}$ and 5$9 \mu \mathrm{m}$ (Fig. 7.13. b.). The SEM images support the grain size distributions, with the $2 \mu \mathrm{m}$ peak reflecting common Gephyrocapsa spp. including Gephyrocapsa protohuxleyi, while the 5$9 \mu \mathrm{m}$ peak mainly consists of Coccolithus pelagicus, Calcidiscus leptoporus, Oolithotus antillarum and the diatom Thalassiothrix spp.

\subsection{Foraminifera species composition}

Planktic foraminiferal species in P71 have been grouped following the scheme in Crundwell et al. (2008) (Table 7.1.). Some species were separated into ocean temperature zones based on the Southern Hemisphere core top database, whereas Globigerina bulloides, Globigerinita glutinata, Turborotalita quinqueloba respond to nutrients as opposed to temperature and so have been grouped as eutrophic species. G. bulloides and G. glutinata reflect mixed layer productivity, occurring early and late in phytoplankton bloom successions, respectively.

The end of MIS 6 in P71 has a foraminifera assemblage dominated by temperate species (Fig. 7.14). During the deglacial into MIS 5e, the temperate species decline, and are replaced by increasing subtropical and eutrophic species. The peak of the interglacial, MIS 5e, is characterised by high percentages of eutrophic species, increasing subtropical fauna, plus very low percentages of subpolar species. The peak in coccolith percentages estimated from grain size occurs later in the interglacial, coincident with MIS 5c/d. Subtropical fauna reach their highest percentages as the coccolithophores increase, while eutrophic and temperate species decrease during this time. This is comparable to the order of changes that occur at MIS 5e in ODP 1123 (Crundwell et al., 2008), where eutrophic species increase during the deglaciation at the expense of temperate fauna, then are replaced by subtropical species at the peak of MIS 5e, with temperate species increasing again in MIS 5d. However, at P71 it 
appears that while the order in which species peak is the same during the interglacial, it is delayed compared with ODP 1123, as the eutrophic fauna peak coincident with MIS 5e, and the subtropical species increasing in MIS $5 \mathrm{~d}$.

The transition from MIS 8 to 7 in P71 is characterised by moderate percentages of subtropical species and high amounts of temperate species. During MIS 7c, the subtropical species increase and the temperate fauna decrease. MIS $7 \mathrm{~b}$ reflects a return to an assemblage more characteristic of the glacials, with low amounts of subtropical species, and high percentages of temperate fauna. Interstadial MIS 7a coincides with the peak in coccolithophore percentages from the grain size record. During this time period, subtropical species increase, temperate and temperate/subtropical species decrease and eutrophic species, which had remained relatively steady during MIS $7 \mathrm{c}$ and $7 \mathrm{~b}$, also decrease. At the end of MIS 7a, and during the start of the transition into MIS 6, eutrophic, temperate and subpolar species increase, while subtropical species decrease. This is also comparable to MIS 7a in ODP 1123, which shows a peak in subtropical fauna, and low abundances of eutrophic species (Crundwell et al., 2008).

\begin{tabular}{|l|l|}
\hline Ecology & Foraminifera Species \\
\hline Sub polar & Neogloboquadrina pachyderma \\
\hline Temperate & $\begin{array}{l}\text { Globigerina falconensis, Neogloboquadrina incompta, } \\
\text { Globorotalia inflata, Globorotalia truncatulinoides (sinistral) }\end{array}$ \\
\hline Temperate/subtropical & $\begin{array}{l}\text { Neogloboquadrina dutertrei, Globorotalia crassula, Globorotalia } \\
\text { scitula, Globorotalia crassaformis (sinistral) }\end{array}$ \\
\hline Subtropical & $\begin{array}{l}\text { Globorotalia truncatulinoides (dextral), Globigerinoides ruber, } \\
\text { Globigerinoides succulifer, Beella digitara }\end{array}$ \\
\hline Eutrophic & $\begin{array}{l}\text { Globigerina bulloides, Globigerinita glutinata, Turborotalita } \\
\text { quinqueloba }\end{array}$ \\
\hline
\end{tabular}

Table 7.1. Temperature and environmental zones for foraminifera species from Crundwell et al. (2008). 


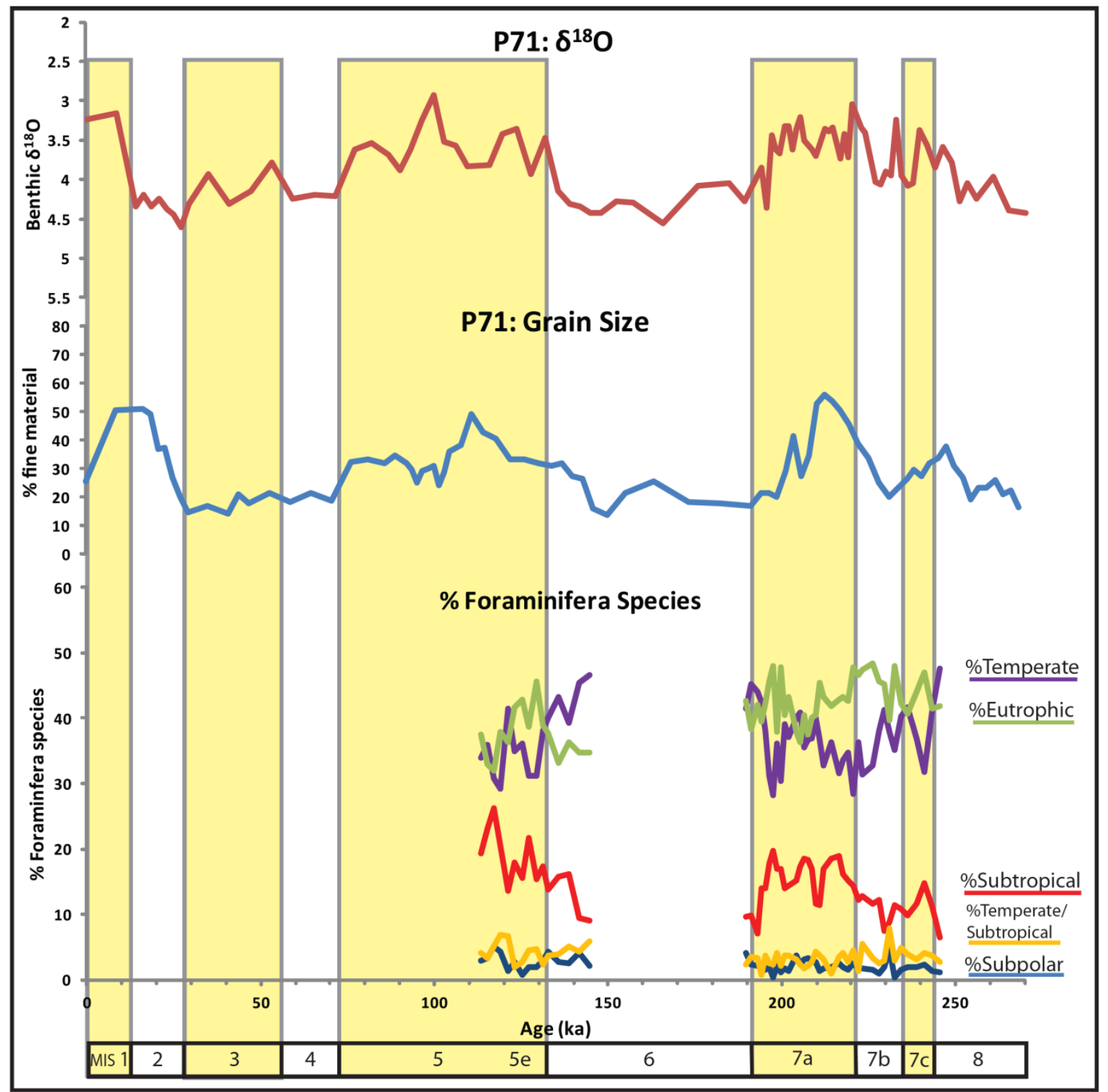

Figure 7.14: Oxygen isotope record, percentage of fine material and foraminfera assemblage percentages for $P 71$.

\subsection{Foraminifera assemblage temperatures}

Foraminiferal assemblage data have been converted into mean annual SST using a RFM (G. Cortese and G. Scott, GNS Science, pers. comm.) (Fig. 7.15). Temperatures throughout MIS

7 and MIS 5e in P71 are comparable to the modern mean annual temperature of $19.34^{\circ} \mathrm{C}$ (CARS, http://www.marine.csiro.au/ dunn/cars2009/). Slightly warmer temperatures, by 1 or $0.5^{\circ} \mathrm{C}$ occur during MIS $7 \mathrm{a}$ and the peak of MIS 5e. The coolest temperature of $15^{\circ} \mathrm{C}$ is at the 
transition from MIS 7a to MIS 6. Cool temperatures of $16-17^{\circ} \mathrm{C}$ also occur in the middle of MIS 7a, and MIS 7b. The end of glacial MIS 6 is not particularly cold at this site, comparable or cooler by $1^{\circ} \mathrm{C}$ than the modern mean annual temperature. Temperatures from Random Forest modelling are overall cooler by $\sim 1^{\circ} \mathrm{C}$ than those derived from the $\mathrm{Mg} / \mathrm{Ca}$ of $G$. ruber (Fig. 7.16).

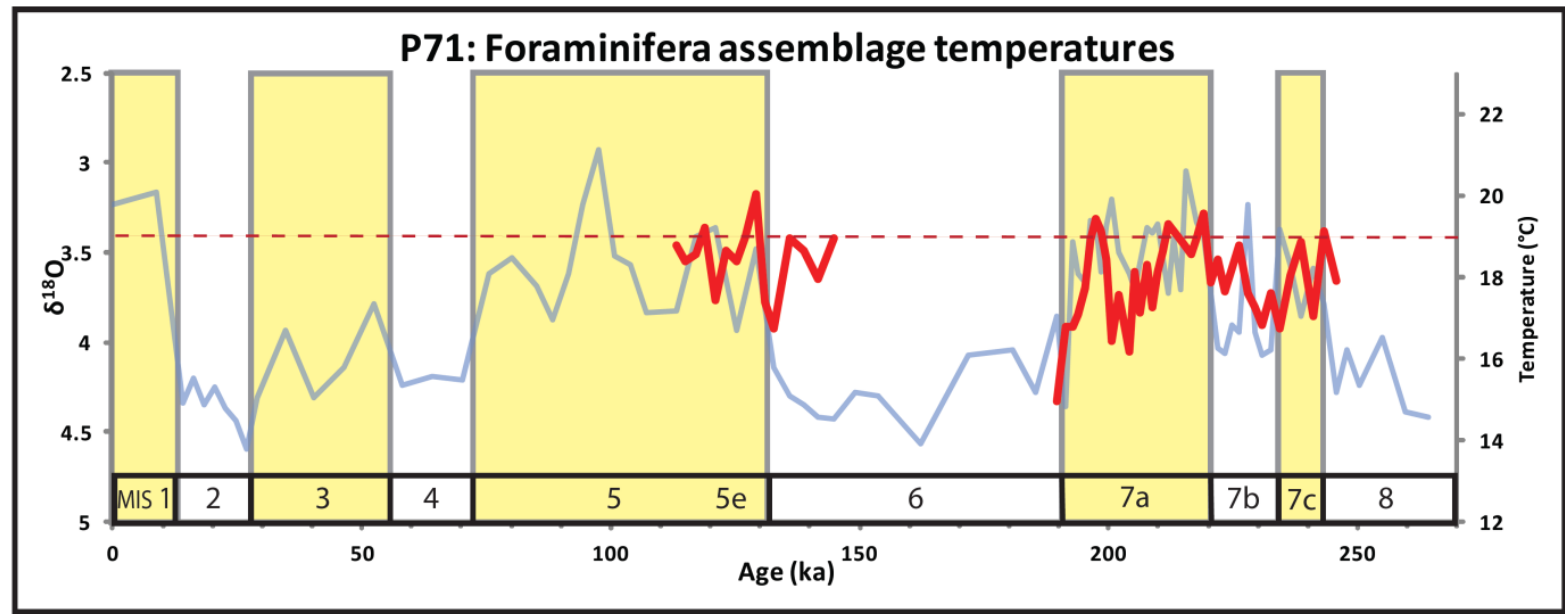

Figure 7.15. Temperatures from Random Forest modelling of foraminiferal assemblage data.

Blue line is the $\delta^{18} \mathrm{O}$ record from Uvigerina spp. Dashed line represents the modern mean annual temperature at P71 from CARS (http://www.marine.csiro.au/ dunn/cars2009/).

\section{8. $\mathrm{Mg} / \mathrm{Ca}$ temperatures}

$\mathrm{Mg} / \mathrm{Ca}$ from in situ analysis on $G$. ruber tests in $\mathrm{P} 71$ have been converted to temperatures using an empirical Southwest Pacific calibration from Bolton et al. (2011) (Fig. 7.16). A near core top sample representative of MIS 1 at $8.58 \mathrm{ka}$ gives a temperature of $19.8^{\circ} \mathrm{C}$, comparable to the modern mean annual temperature of $19.34^{\circ} \mathrm{C}$ at the site (CARS, http://www.marine.csiro.au/ dunn/cars2009/ ). Temperatures across MIS 7 remain relatively consistent between stadial and interstadials, with an average of $\sim 20^{\circ} \mathrm{C}$. Cooler temperatures are found at the transition between MIS $7 \mathrm{a}$ and MIS 6 of $18.5^{\circ} \mathrm{C}-18.3^{\circ} \mathrm{C}$, and during the transition from MIS 8 to MIS 7c, with a temperature of $19^{\circ} \mathrm{C}$. A warm peak occurs during 
MIS 7a, reaching $22^{\circ} \mathrm{C}$ at 208.7ka. Samples representative of glacial MIS 6 at $141.8 \mathrm{ka}$, and MIS 8 at $250.3 \mathrm{ka}$ give temperatures of $19.7^{\circ} \mathrm{C}$ and $20.3^{\circ} \mathrm{C}$ respectively, also slightly warmer than the modern mean annual temperature. This suggests only a minor glacial-interglacial difference in temperature at this site, of $1-2^{\circ} \mathrm{C}$.

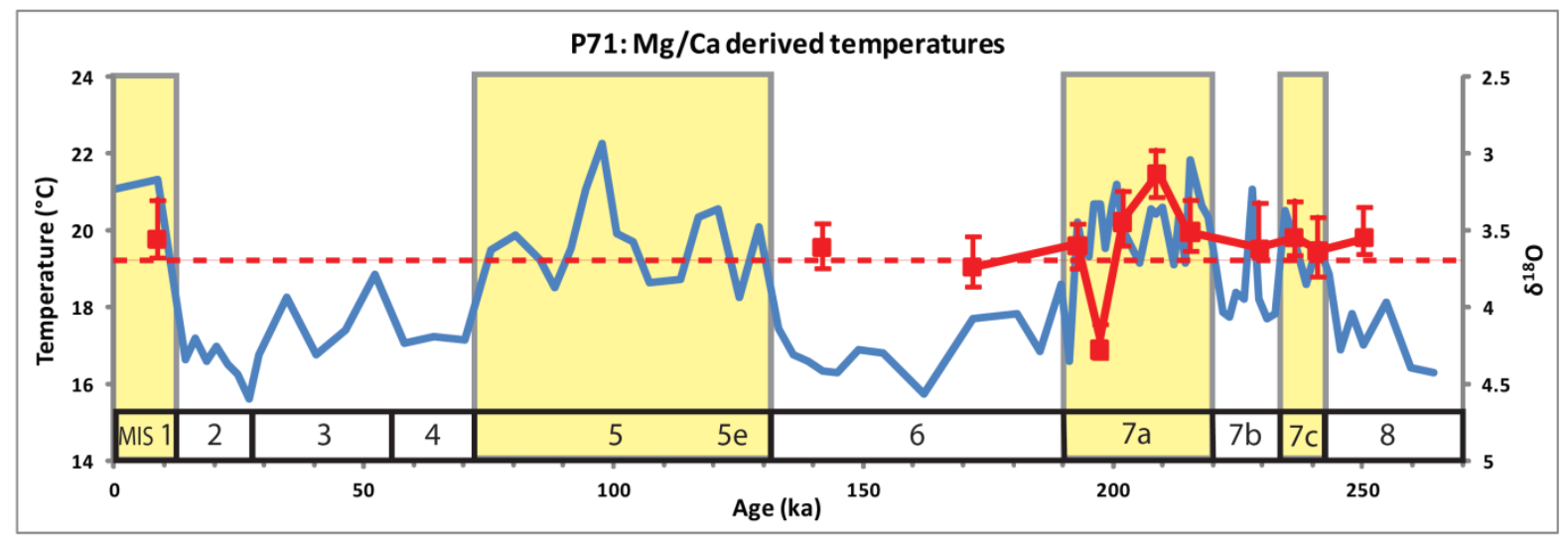

Figure 7.16: Temperatures derived from $\mathrm{Mg} / \mathrm{Ca}$ analysis of G.ruber. Blue line is the $\delta^{18} \mathrm{O}$ record from Uvigerina spp. Red dashed line represents the modern mean annual temperature at the core site from CARS (http://www.marine.csiro.au/ dunn/cars2009/).

\subsection{Oxygen Isotopes}

Figures 7.17 and 7.18 shows the corrected and uncorrected values of $\delta^{18} \mathrm{O}$ for ODP 1120 and P71. Following the consistent offset described in the literature between Uvigerina spp. and Cibicidoides spp., $0.64 \%$ has been added to the values of Cibicidoides spp. to correct for vital effects in the uptake of $\delta^{18} \mathrm{O}$ into the species test, and to make them ' $u v i$-equivalent' (Shackleton and Opdyke, 1973, McCave et al., 2008). 


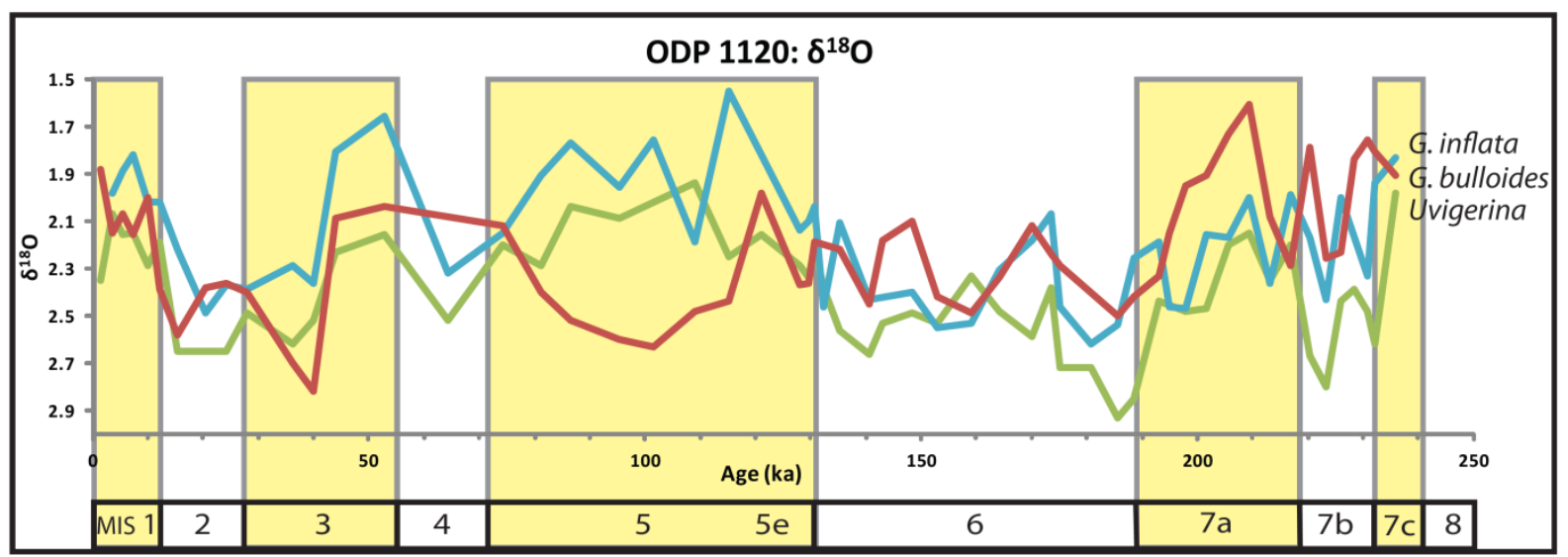

Figure 7.17: $\delta^{18} O$ values for G. inflata, G. bulloides and Uvigerina spp. in ODP 1120.

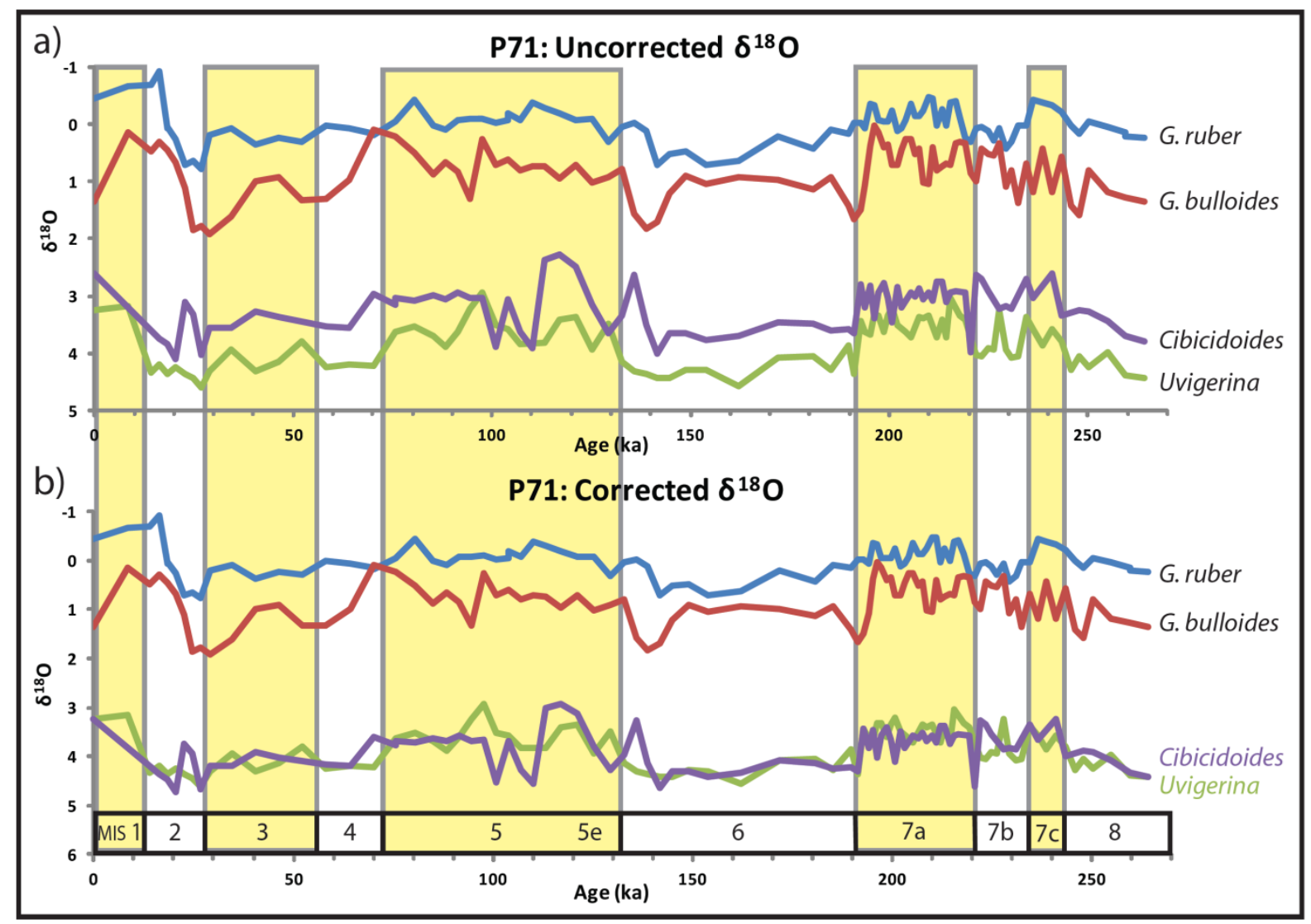

Figure 7.18: Uncorrected (a) and corrected $(b) \delta^{18} O$ values for $G$ ruber, G. bulloides,

Cibicidoides spp. and Uvigerina spp. for P71. Values have been corrected to take into account vital effects in the uptake of $\delta^{18} O$ into the species test, and to make Cibicidoides spp. uvi-equivalent (Shackleton and Opdyke, 1973, McCave et al., 2008).

The $\delta^{18} \mathrm{O}$ difference between species' of planktic foraminifera dwelling at different depths of the water column can be used as a proxy for stratification (Mulitza et al., 1997, Ganssen and 
Kroon, 2000). Ice volume and disequilibrium processes from carbonate chemistry are the same for each species at each point in time, and so the difference in $\delta^{18} \mathrm{O}$ should reflect the temperature of each species different calcification depth (Neil et al., 2004). The difference between $G$. ruber and G. bulloides is used at P71, and the difference between G. bulloides and G. inflata is used for ODP 1120 (Fig. 7.19). This method assumes that both species have their production peaks in the same season, which is supported by sediment trap data for $G$. inflata and G. bulloides on the Campbell Plateau (Northcote and Neil, 2005). It is assumed that $G$. ruber and $G$. bulloides also have production peaks at a similar time at P71. The species will have similar values of $\delta^{18} \mathrm{O}$ if the upper water column is well mixed and isothermal, and different values from each other if the water column is thermally stratified. Using the temperature and oxygen isotope relationship of $0.23 \% /{ }^{\circ} \mathrm{C}$ established by Chappell and Shackleton (1986), the temperature that the species difference represents can be determined.

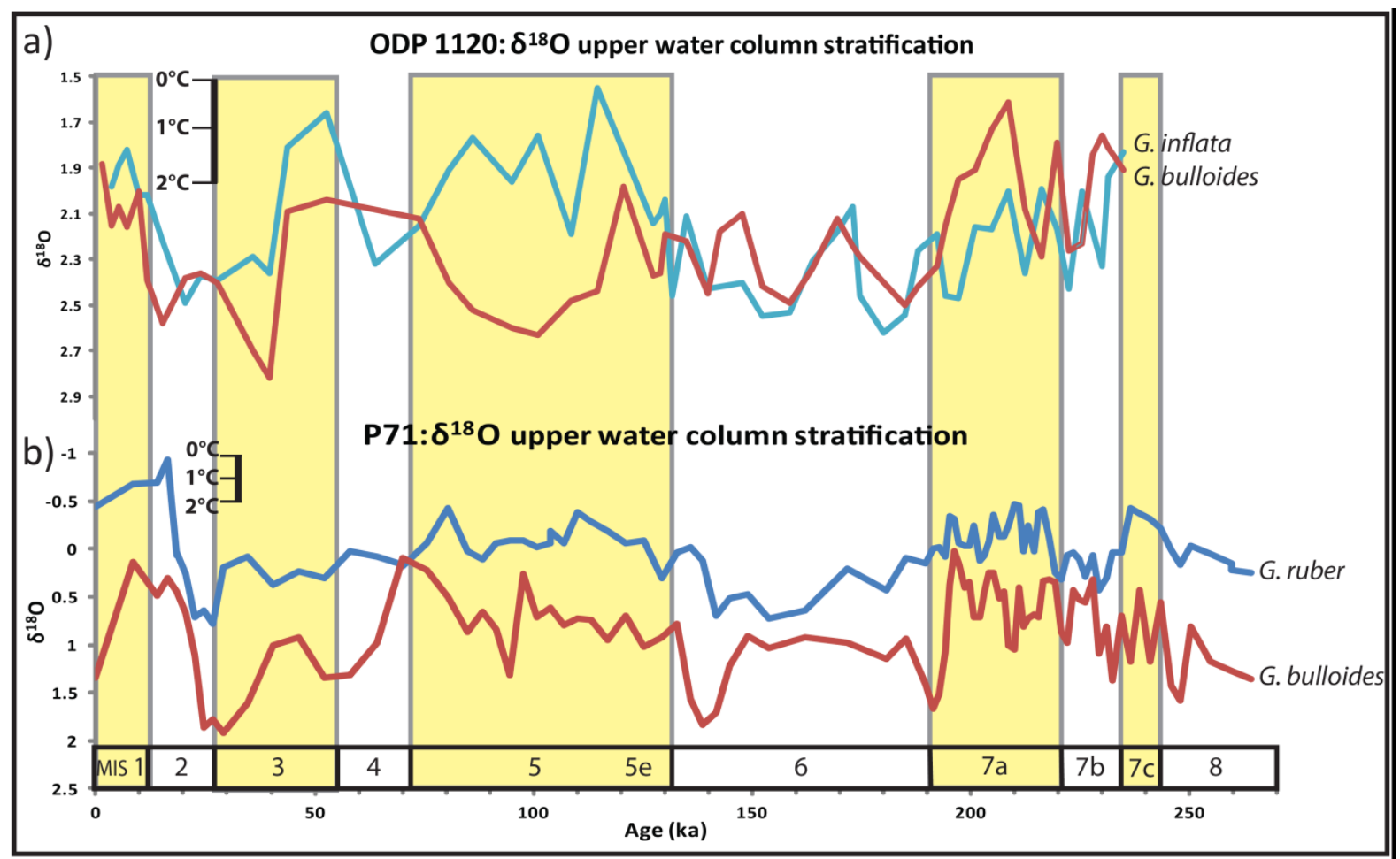

Figure 7.19: Difference in $\delta^{18} O$ between $G$. inflata and G. bulloides in ODP 1120 (a), and between $G$. ruber and G. bulloides in P71 (b) representing upper water column stratification. 
Temperature scale shows the temperature change that the difference between the two species represents (Chappell and Shackleton, 1986)

Results from P71 suggest a water column that is well stratified, indicated by the consistent offset between $G$. ruber and $G$. bulloides down core. There are however times when the values are much more similar, suggesting a well mixed upper water column; namely during MIS 2, the beginning of MIS 4, the end of MIS 7a, and MIS 7b. The temperature differences between the two species here are relatively large reaching $4-5^{\circ} \mathrm{C}$ when the water column is most stratified, and $\sim 1{ }^{\circ} \mathrm{C}$ when it is most mixed. In ODP 1120 , the values of $G$. bulloides and G. inflata are consistently similar; indicating that a well mixed upper water column exists at this site. MIS 7a is the only time when values of $G$. inflata are significantly more positive that G. bulloides. Unusually there are times, such as the majority of MIS 5, when the deeper dwelling $G$. inflata is actually more depleted in $\delta^{18} \mathrm{O}$ than $G$. bulloides. The temperature change that this represents would suggest a $2-3^{\circ} \mathrm{C}$ difference between the species.

\subsection{Trace Element Analysis}

Manganese and zinc are important trace metals for phytoplankton growth (Zondervan, 2007, Morel et al., 2003). Zinc has a nutrient-style distribution in the water column, with lower abundances occurring in surface waters due to high assimilation by phytoplankton, and high abundances in deepwater water due to release by deceased phytoplankton (Bruland and Lohan, 2003, Ellwood, 2004). Data collected from around New Zealand supports low Zn in surface waters, increasing with depth (Ellwood, 2004). Manganese has the opposite distribution with high values in surface waters due to indirect photochemical reductive dissolution of Mn oxide (Morel et al., 2003). However comparisons between G. ruber in plankton tows and G. ruber in the P71 core top (A. Bolton, HKU, pers. comm.), suggests that the $\mathrm{Mn} / \mathrm{Ca}$ values recorded down core in P71 may be affected by diagenetic alteration. Marr 
et al. (in prep.) has shown that the $\mathrm{Zn} / \mathrm{Ca}$ ratio of $\mathrm{G}$. ruber reflects values typical of $\mathrm{Zn} / \mathrm{Ca}$ in STW. Variations in this ratio can be considered to reflect variations in $\mathrm{Zn} / \mathrm{Ca}$ in the surface waters at P71, and therefore may indicate changes in phytoplankton productivity. Trace element data from $G$. ruber show a peak in both $\mathrm{Zn} / \mathrm{Ca}(0.066 \mathrm{mmol} / \mathrm{mol})$ and $\mathrm{Mn} / \mathrm{Ca}$ $(0.047 \mathrm{mmol} / \mathrm{mol})$ coincident with the greatest coccolith abundances during MIS 7a (Fig. 7.20). The near core top sample has high values for $\mathrm{Zn} / \mathrm{Ca}(0.069 \mathrm{mmol} / \mathrm{mol})$ and $\mathrm{Mn} / \mathrm{Ca}$ $(0.061 \mathrm{mmol} / \mathrm{mol})$, also coincident with a high percentage of coccoliths. Further work and study is required to determine what these trends may represent and if they can be used as proxies of micro-nutrient abundance, or if values instead reflect diagenetic or biological effects within the foraminifera test.

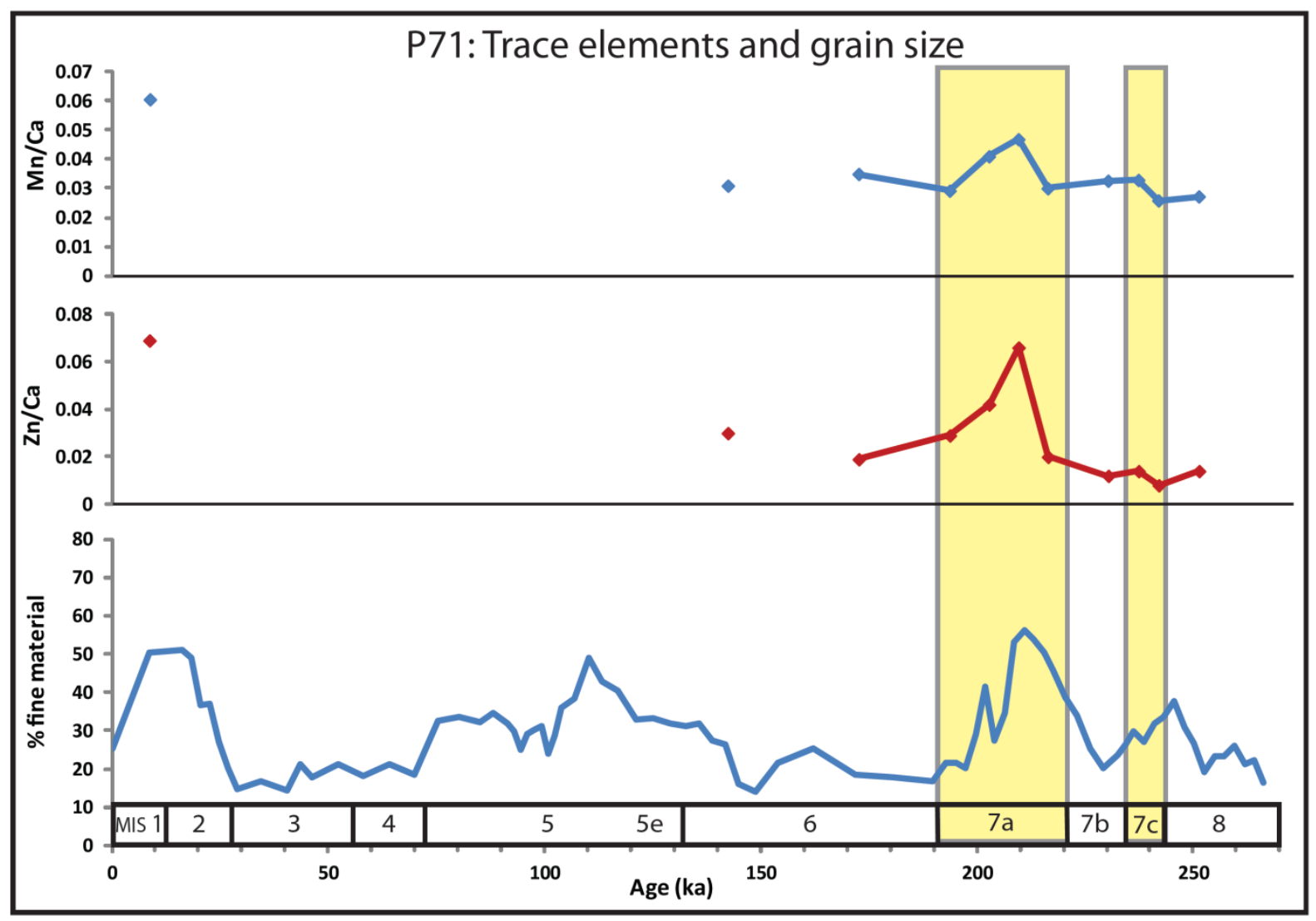

Figure 7.20: Trace element ratios of $\mathrm{Mn} / \mathrm{Ca}$ and $\mathrm{Zn} / \mathrm{Ca}$ compared to the percentage of $<20 \mu m$ material. 


\section{DISCUSSION}

This Chapter present an overview of conditions in the Southwest Pacific during MIS 7. While MIS 5e has been extensively studied in the Southwest Pacific, MIS 7 has been relatively overlooked. By examining the current literature, coupled with findings from this study, some inferences can be made about the manifestation of MIS 7 in this region. This is followed by detailed paleo-environmental reconstructions for P71 and ODP 1120 during MIS 5e and MIS 7a. These reconstructions are based on results from section 7 and when appropriate, from previously published work, in order to determine conditions under which coccolithophore blooms occur at each core site. Lastly, this chapter discusses the potential for changes in coccolithophore productivity at the core sites in the future, using the conditions that have favoured blooms in the past, coupled with projected oceanic trends.

\subsection{Southwest Pacific in MIS 7}

SSTs in MIS 7a at P71, and across the Tasman Front (Kawagata, 2001), are comparable to present temperatures (Fig. 4.3). This similarity suggests the Tasman Front was in a similar position to present during MIS 7a. However, during MIS 7c, SSTs suggest the Tasman Inflow was $\sim 1.5^{\circ} \mathrm{C}$ cooler than present (Kawagata, 2001). This may represent a more northerly position of Tasman Front, or a change in inflow from the EAC. The inflow into the Tasman Front is dependent on the wind stress curl (the gradient of wind stress on the surface ocean) across the Pacific Ocean, as greater wind stress curl results in heightened flow along the southern extension of the EAC, at the expense of flow into the Tasman Front (Hill et al., 2008). While overall productivity in STW and SAW around New Zealand was thought to have been comparable to present during MIS 7 (Section 4.7) (Nelson et al., 1986, Hall et al., 2001, Schaefer et al., 2005, Hayward et al., 2012), the Tasman Front is interpreted to have increased mixing and productivity during MIS 7, but not during MIS 5e (Kawagata, 2001). 
This may also be related to changes in flow into the Tasman Front affecting frontal eddy systems and changing the mixing regime. The same pattern of higher productivity in MIS 7a, and lower productivity in MIS 5e, also occurs at P71 (Sections 7.3 and 7.4).

The compilation of SSTs from MIS 7 suggests that the STF on the Chatham Rise was located in approximately the same position as now, which is dynamically positioned over the crest of the rise (Fig. 4.3). However, warmer temperatures to the north of the Chatham Rise during both MIS 7a and MIS 7c, and cooler temperature to the south, particularly during MIS 7a, suggest that the temperature gradient across the STF was larger than present, i.e. $>2^{\circ} \mathrm{C}$ per $1^{\circ}$ latitude (Pahnke et al., 2003, Pelejero et al., 2006, Hayward et al., 2008, Lüer et al., 2009, Hayward et al., 2012). In the south Tasman Sea, however, temperatures from E36-23 (G. Scott, GNS Science, pers. comm.) and MD06-2986 (Hayward et al., 2012) near the current position of the STF are cooler during both times periods, and markedly cooler during MIS 7a, implying that the STF may have been located in a slightly more northerly position, bathing the core sites in cooler SAW. In contrast during MIS 5e, SSTs south of Tasmania were $\sim 2^{\circ} \mathrm{C}$ warmer than present, suggesting a more southerly position of the STF (Sikes et al., 2009). SSTs in MIS 7 from SO136-GC3 are up to $4^{\circ} \mathrm{C}$ warmer than the STW core sites nearby. SSTs from Fr94-GC3 are $3-5^{\circ} \mathrm{C}$ warmer in MIS 7 than neighbouring core E36-23. SSTs from these cores are based on alkenones, and may represent a summer SST at each core site, rather than an annual average (Sikes et al., 2005, Barrows et al., 2007, Sikes et al., 2009). Sea level estimates do not suggest a significant enough lowering or increase during MIS 7 compared with present, to have had an affect on ocean circulation (Section 4.5) (Pillans et al., 1988, Lea et al., 2002, Siddall et al., 2007, Dutton et al., 2009, Rohling et al., 2009)

In MIS 7c, SAW was not significantly cooler than present (Pahnke et al., 2003, Hayward et al., 2008, Lüer et al., 2009). In contrast, SAW was cooler than present in MIS 7a (Pahnke et 
al., 2003, Hayward et al., 2008, Lüer et al., 2009), coinciding with a peak in IRD on the Campbell Plateau (Carter et al., 2002), and near Antarctica (Section 4.6) (Grobe and Mackensen, 1992, Kanfoush et al., 2002, Teitler et al., 2010). Temperatures over Antarctica were cooler than present in MIS 7a by $\sim 2^{\circ} \mathrm{C}$ (Petit et al., 1999, Jouzel et al., 2007). This may have resulted in cooler polar waters and SAW, allowing icebergs to travel further north before melting, leading to an increase in IRD on the Campbell Plateau.

Terrestrial records during MIS $7 \mathrm{a}$ and $7 \mathrm{c}$ would be expected to reflect comparable temperatures to present, as the STW which influences New Zealand's climate reflects similar and slightly warmer temperatures to modern. Terrestrial records of MIS 7 do suggest that on land temperatures and conditions were similar to today (Section 4.8) (Pillans et al., 1988, Mildenhall, 1995, Bussell and Pillans, 1997, Shulmeister et al., 1999, Soons et al., 2002, Marra et al., 2006).

\subsection{Timing of coccolithophore blooms}

Using grain size to distinguish between coccolithophores and foraminifera (Section 7.4, Fig. 7.7), sections within P71 ( MIS 7a- 208-215ka, and MIS 1/2) and ODP 1120 (MIS 5e- 110130ka) cores were identified as times when coccolithophores bloomed or were the dominant calcareous plankton accumulating and preserved on the sea floor.

Coccolithophores usually sink to the seafloor as aggregates, or attached to the faecal pellets of zooplankton, at rates of up to 160m/day (Honjo, 1976). Thus high abundances of coccolithophores are unlikely to settle far from where they lived. Using this settling rate, at P71 it would take 12 days for coccoliths to reach the seabed in still water. Current speed at P71 decreases with depth in the NCE, from $24 \mathrm{~cm} / \mathrm{s}$ at the surface to $10 \mathrm{~cm} / \mathrm{s}$ at $1000 \mathrm{~m}$ (Stanton et al., 1997). Using $10 \mathrm{~cm} / \mathrm{s}$ as an average speed over $1919 \mathrm{~m}$, the maximum distance coccoliths could travel while falling through the water column is $\sim 100 \mathrm{~km}$. On the Campbell 
Plateau the core site sits $543 \mathrm{~m}$ deep with average current speeds of $10 \mathrm{~cm} / \mathrm{s}$ (Stanton and Morris, 2004). The maximum distance coccoliths could travel before reaching the seafloor here is $\sim 30 \mathrm{~km}$. Coccoliths found in the cores are therefore representative of local conditions, and would have lived within $100 \mathrm{~km}$ of P71, upstream in the EAUC or in the NCE, and $30 \mathrm{~km}$ of ODP 1120, in the weak anticyclonic circulation around the Pukaki Rise.

Based on the present literature the key factors in the formation of coccolithophore blooms are a complex interplay between the stratification of the upper water column, light intensity, nutrient abundance and competition with other plankton (Section 5.2) (Rost and Riebesell, 2004, Tyrrell and Merico, 2004, Trimborn et al., 2007, Zondervan, 2007). While temperature changes are not regarded as a significant direct causal factor in the formation of blooms (Tyrrell and Merico, 2004), temperature does affect the relative abundance and dominance of different species of coccolithophores and can contribute to enhancing stratification (Tyrrell et al., 1999, Herrmann et al., 2012). Stratification in turn affects the abundance of nutrients in the surface ocean (Tyrrell and Merico, 2004, Zondervan, 2007, Holligan et al., 2010). Ocean conditions during the times of blooming in each core are described in the following section.

\subsection{P71: Conditions during blooms in MIS 7a}

\subsubsection{Temperature}

$\mathrm{Mg} / \mathrm{Ca}$ G. ruber and RFM-derived temperatures from the foraminiferal assemblages across MIS 7a differ (Fig. 8.1). RFM temperatures are consistently cooler by $\sim 1^{\circ} \mathrm{C}$. RFM is trained to output an annual temperature, while the $\mathrm{Mg} / \mathrm{Ca}$ of $\mathrm{G}$. ruber is calibrated on the assumption that the difference between spring/summer SST during G. ruber's bloom season, and the mean annual SST is constant over time (Bolton et al., 2011). The difference between temperature proxies may then be a result of a different seasonal SST variation in MIS 7, or a bias in the G. ruber analyses towards individuals that calcified during summer. It is therefore 


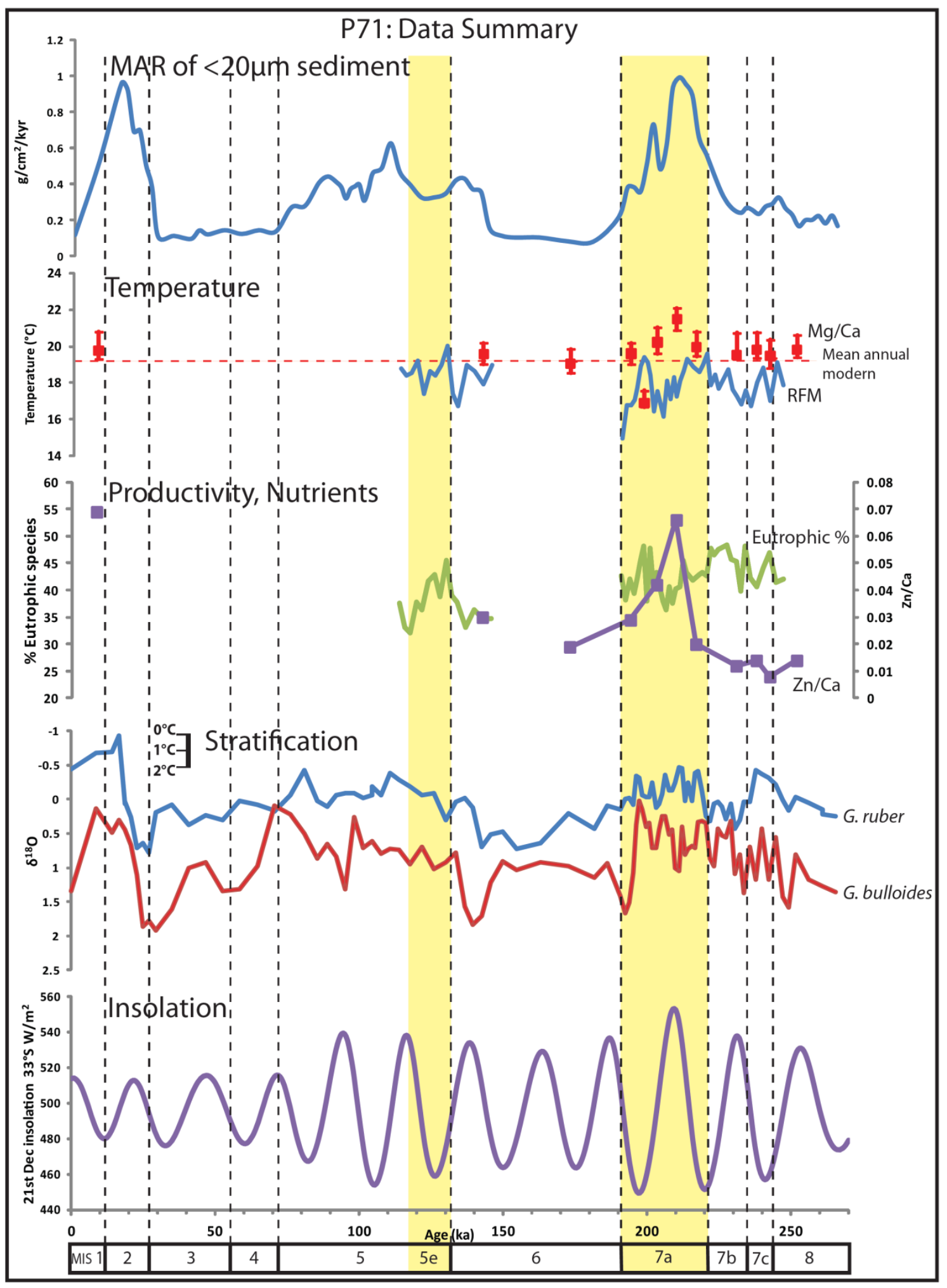

Figure 8.1. Composite figure of key data sets for P71.

expected that RFM should be comparable to the modern mean annual temperature of $19.34^{\circ} \mathrm{C}$ (Sutton and Roemmich, 2001, CARS, http://www.marine.csiro.au/ dunn/cars2009/) whilst 
$\mathrm{Mg} / \mathrm{Ca}$ would give a slightly warmer temperature. RFM temperatures show the start of MIS 7a to be warmer than $7 \mathrm{c}$ by $\sim 0.5^{\circ} \mathrm{C}$, while from $\mathrm{Mg} / \mathrm{Ca}$ G. ruber this difference is $2-3^{\circ} \mathrm{C}$. Warmer temperatures than present in MIS 7a is supported by Modern Analogue Technique foraminiferal assemblage temperature data from Kawagata (2001), for the more northerly reach of the Tasman inflow (NGC 99 and 98, Fig 4.3). In contrast STW further south around New Zealand is warmer during MIS 7c by $1-2^{\circ} \mathrm{C}$ (Calvo et al., 2004, Pelejero et al., 2006, Hayward et al., 2008, Hayward et al., 2012). The warmest part of MIS 7a is $22^{\circ} \mathrm{C}$ at $209 \mathrm{ka}$ from $\mathrm{Mg} / \mathrm{Ca} G$. ruber, and $18.1-19.6^{\circ} \mathrm{C}$ between $210-219 \mathrm{ka}$ from $\mathrm{RFM}$ temperature estimates. These peaks in temperature in MIS 7 coincide with coccolithophore blooms. RFM SST data also encompasses MIS 5e, a period shown in ice core records to be a warmer interglacial than MIS 7 in Antarctica (Petit et al., 1999, Jouzel et al., 2007). However at P71, MIS 7 and MIS 5e SSTs are similar. Only during the late stages of MIS 5e (129.2ka) does the RFM SST briefly exceed that of MIS 7a, reaching $20^{\circ} \mathrm{C}$ (Fig. 8.1). Warm temperatures during MIS 5e do not, however, coincide with a peak in coccolithophore blooms at P71. $\mathrm{Mg} / \mathrm{Ca} G$. ruber analyses at $8 \mathrm{ka}$, during the Holocene, indicate a temperature of $19.75^{\circ} \mathrm{C}$, slightly warmer than present, but not as high as $\mathrm{Mg} / \mathrm{Ca}$ G. ruber values from the MIS 7a blooms.

\subsubsection{Insolation (light) intensity}

Coccolithophore blooms often occur under conditions of higher than average light intensity (Tyrrell and Merico, 2004, Zondervan, 2007). E. huxleyi in particular responds favourably to high light saturation in the upper water column (Tyrrell and Merico, 2004, Trimborn et al., 2007). During the coccolithophore blooms of MIS 7a in P71, peak summer insolation intensity reached $553 \mathrm{~W} / \mathrm{m}^{2}, 39 \mathrm{~W} / \mathrm{m}^{2}$ higher than present values (Section 4.3, Fig. 8.1) (Berger et al., 1992). Increased insolation potentially favoured coccolithophores that are more tolerant of high light levels than other phytoplankton (Tyrrell and Merico, 2004). The first 
appearance of E. huxleyi is $268 \mathrm{ka}$, but it did not become dominant until $85 \mathrm{ka}$ in subtropical waters and $73 \mathrm{ka}$ in colder waters when it became more common than Gephyrocapsa spp., in particular Gephyrocapsa caribbeanica (Thierstein et al., 1977). The blooms in MIS 7a in P71 are also dominated by Gephyrocapsa spp., in this case mainly G. oceanica and G. aperta, however the tolerance and reactions of these species to high light intensities is unknown.

\subsubsection{Water column stratification}

Coccolithophores require a stratified water column with a mixed layer depth of $\sim 10-20 \mathrm{~m}$ and certainly <30m to form blooms (Head et al., 1998, Tyrrell and Merico, 2004, Trimborn et al., 2007, Iida et al. 2012). The $\delta^{18} \mathrm{O}$ difference between G. ruber and G. bulloides is used here as a proxy for upper water column stratification at P71 (Fig. 8.1) (Carter et al., 2008). The values of each species are consistently offset suggesting the upper water column was usually well stratified at this site (Fig. 8.1). However, MIS 7b and the end of MIS 7a both show similar $\delta^{18} \mathrm{O}$ values for each species suggesting a well-mixed upper water column, but in early and mid-MIS 7a the $\delta^{18} \mathrm{O}$ values for $G$. ruber and G. bulloides diverge, indicating a stratified upper water column coincident with the MIS 7a coccolithophore blooms.

\subsubsection{Productivity and nutrients}

The blooms of coccolithophores in MIS 7a coincide with peaks in $\mathrm{Zn} / \mathrm{Ca}$ in $G$. ruber (Fig. 8.1). Further study is required to determine if $\mathrm{Zn} / \mathrm{Ca}$ in foraminifera tests is incorporated in a way that reflects $\mathrm{Zn}$ values in the surrounding water, or if it is controlled by physiological ("vital") effects or diagenetic alteration. Nonetheless, if it is assumed that $\mathrm{Zn} / \mathrm{Ca}$ G. ruber reflects actual micro-nutrient abundances, then some potential reasons can be speculated as to why a peak in $\mathrm{Zn} / \mathrm{Ca}$ coincides with coccolithophores blooms. As $\mathrm{Zn}$ is scavenged in surface waters, high $\mathrm{Zn} / \mathrm{Ca}$ G. ruber values would be expected to occur when surface productivity is 
low as $\mathrm{Zn}$ is left unutilised by phytoplankton, the opposite of what occurs in P71. There are several ways in which $\mathrm{Zn}$ may be enhanced in surface waters. Upwelling of deeper water could bring Zn-rich waters to the surface; however the $\delta^{18} \mathrm{O}$ difference between G. ruber and G. bulloides in P71 shows that the upper water column was stratified during the coccolithophore blooms of MIS 7a. High Zn can also result from enhanced fluvial inputs (Gaillardet et al., 2003). P71 is situated far from significant inputs of terrigenous material from rivers (Hicks and Shankar, 2003), particularly as the source of the surface water at this site is from the Tasman Front and the EAUC (Stanton, 1973) with little input from the New Zealand land mass. High $\mathrm{Zn} / \mathrm{Ca}$ recorded in $G$. ruber must therefore be the result of another mechanism.

High coccolithophore concentrations reflect light entering the water resulting in warmer, brighter surface layers (Tyrrell et al., 1999). This causes cooler, darker waters below the surface and decreased productivity (Tyrrell et al., 1999). STW is seasonally macro-nutrient depleted (Boyd et al., 1999), and stratification in spring and summer and further limits macro and micro-nutrient availability in the upper water column (Baumann et al., 2004, Rost and Riebesell, 2004). Decreased productivity below the surface waters is shown in the decrease in abundance of eutrophic foraminifera, such as thermocline dwelling G. bulloides (Hemleben et al., 1989, Mortyn and Charles, 2003, Crundwell et al., 2008), during the coccolithophore blooms (Fig. 8.1). Optimal habitat for G. bulloides is when nutrients are brought into the euphotic mixed layer by upwelling or entrainment of deeper waters (Schiebel et al., 2001); stratification is a barrier for this process and would be expected to restrict G. bulloides. The abundance of subtropical, symbiont-bearing G. ruber does not decrease with light restriction below the surface. As G. ruber has a depth range of 0-50m (Hembleben et al., 1989, Dekens et al., 2002), it may be able to move through the upper water column to source food and nutrients, and perhaps its growth is not as restricted by the blooms as the thermocline 
dwelling species. As Zn reflects a micro-nutrient distribution in the water column, the surface $\mathrm{Zn}$ may have been scavenged by increased phytoplankton productivity, but lower productivity below the surface would leave relatively more $\mathrm{Zn}$, resulting in $G$. ruber recording enhanced $\mathrm{Zn} / \mathrm{Ca}$ values. However, further work on the incorporation of $\mathrm{Zn}$ into $G$. ruber would be required to support this idea.

The MAR of $\mathrm{CaCO}_{3}$ represents changes in carbonate productivity recorded in ocean sediments, as a burial flux (Section 7.3) (Hodell et al., 2001). As no significant dissolution of carbonate occurs in P71 and ODP 1120, burial flux is regarded as a reasonable representation of biogenic carbonate production in the overlying water column. The peaks in $\mathrm{MAR} \mathrm{CaCO}_{3}$ in P71 coincide with MIS 7a, and also with the blooms of MIS 1/2. The MAR <20 $\mu \mathrm{m}$ shows that the changes in carbonate productivity occur within the fine fraction, and so the large peaks in $\mathrm{MAR} \mathrm{CaCO}_{3}$ represent increases in carbonate derived from coccolithophores as opposed to foraminifera. The combination of trace element data, reduced eutrophic foraminifera, and the MAR $\mathrm{CaCO}_{3}$ shows that surface productivity was high in MIS 7a, leading to an enhanced flux of $\mathrm{CaCO}_{3}$ to the seafloor, but below the surface waters, productivity decreased.

In summary, coccolithophores blooms during MIS 7a occurred at a time of peak summer insolation, when regional warming of the surface ocean produced strong thermal stratification and high light levels favourable for coccolithophores. These conditions, coupled with an albedo effect from the light reflective blooms, reduced light and nutrients below the surface restricting productivity of eutrophic foraminifera (Fig. 8.2). 


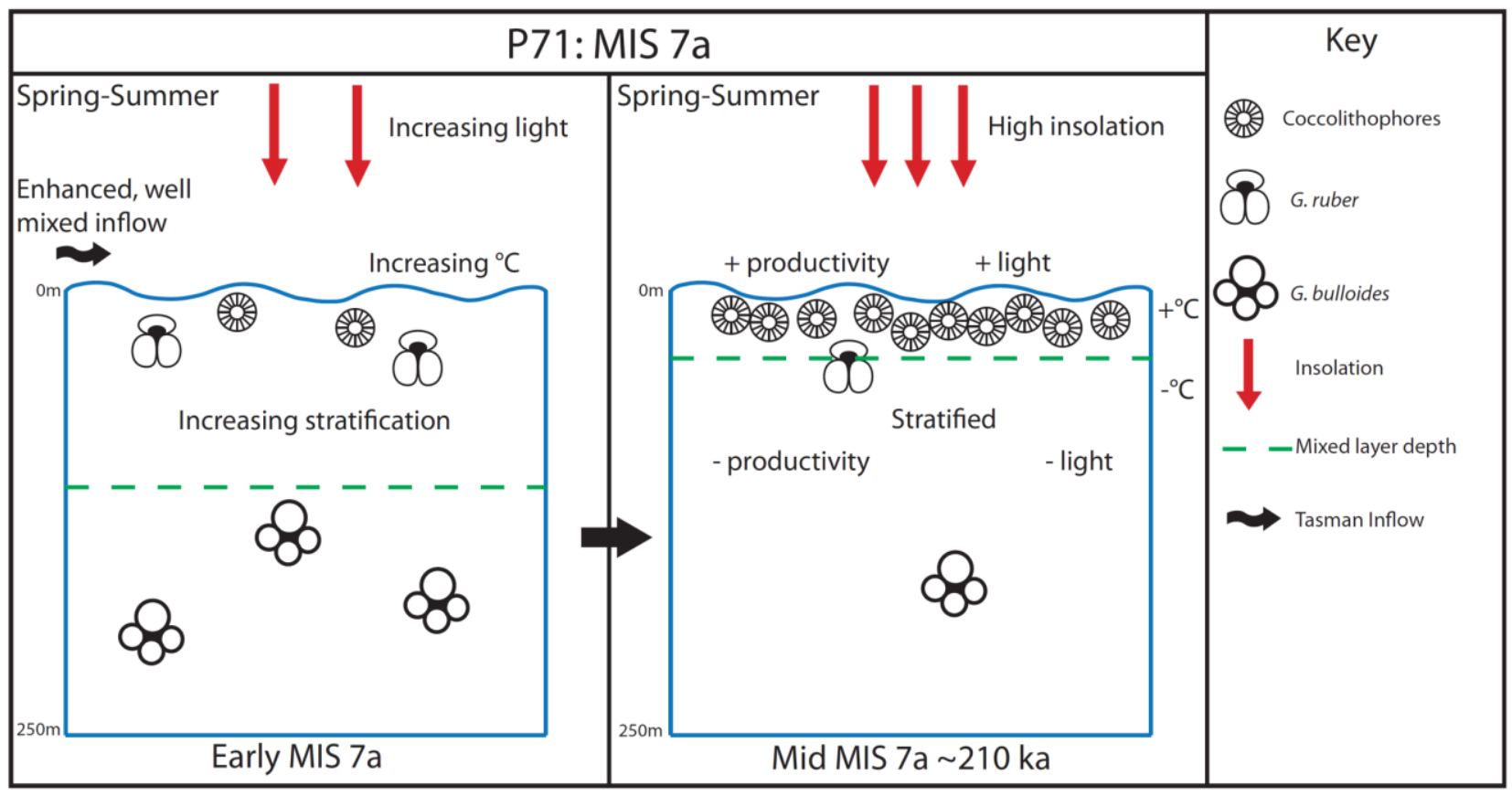

Figure 8.2: Schematic diagram of upper water column conditions during MIS 7a at P71.

\subsection{ODP 1120: Conditions during blooms in MIS 5e}

\subsubsection{Temperature}

ODP 1120 does not have $\mathrm{Mg} / \mathrm{Ca}$ or foraminiferal assemblage temperatures but an indication of sea surface temperature can be derived from the dominant species of coccolithophore during the blooms of MIS 5e (Fig. 7.12). G. caribbeanica lives in SST's between $5-21^{\circ} \mathrm{C}$ with maximum abundances coincident with SSTs of $13-19^{\circ} \mathrm{C}$ (Bollmann, 1997). The overwhelming dominance of G. carribbeanica during MIS 5e suggests that it bloomed under optimal conditions. Even a temperature of $13^{\circ} \mathrm{C}$, the lower end of its favourable conditions, requires an increase in temperature of $4-5^{\circ} \mathrm{C}$ during MIS 5e compared to a modern mean annual temperature of $\sim 8-8.5^{\circ} \mathrm{C}$ (Morris et al., 2001). Furthermore temperatures for MIS 5e in ODP 1120 and nearby SO136-55 were estimated by Neil et al. (2004) using the $\delta^{18} \mathrm{O}$ of $G$. bulloides and G. inflata, and applying a conversion of $1^{\circ} \mathrm{C}$ of temperature change as 


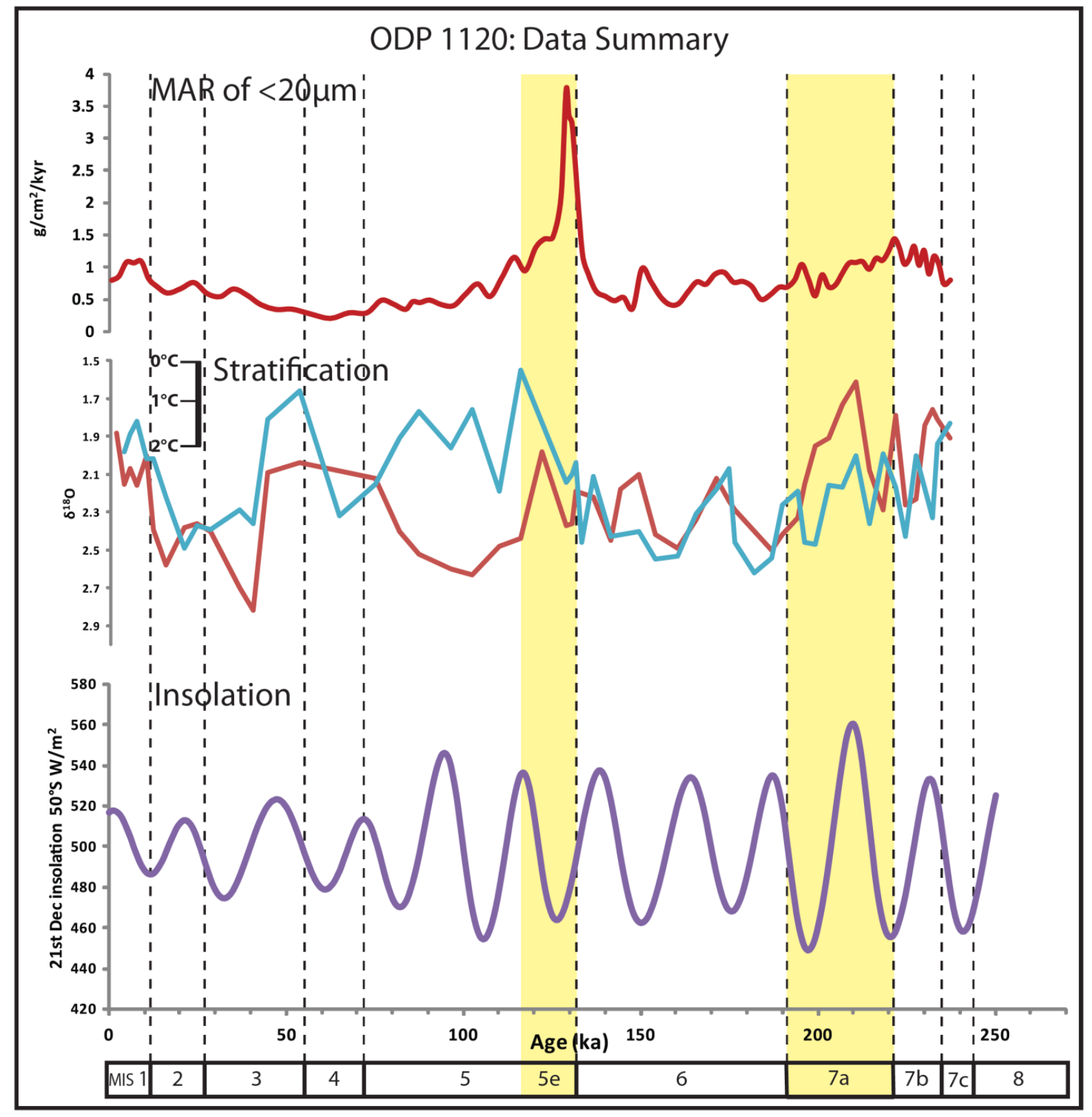

Figure 8.3.Composite figure of key data sets for ODP 1120.

equivalent to $0.24 \%$ o $\delta^{18} \mathrm{O}$. They find temperature differences compared to modern at ODP 1120 and SO136-55 of $+1.98^{\circ} \mathrm{C}$ and $+1.42^{\circ} \mathrm{C}$ for $G$. bulloides and $+1.55^{\circ} \mathrm{C}$ and $+0.95^{\circ} \mathrm{C}$ respectively. These values are less than those suggested by the coccolithophores assemblage data; however both G. bulloides and G. inflata would record a deeper temperature, of 25$125 \mathrm{~m}$ and 50-300m below the surface (Mortyn and Charles, 2003), than coccolithophores which dwell at the surface. The albedo effect of blooms may also play a role (Tyrrell et al., 1999) to enhance cooling of the subsurface and accentuate the thermal gradient. The nearest 
quantitative RFM estimates for SST in this region are $+0.7^{\circ} \mathrm{C}$ and $+0.8^{\circ} \mathrm{C}$ change from modern at SO136-38 (141 km from ODP 1120) and MD97-2109 (292 km from ODP 1120), respectively (G. Cortese, GNS Science, pers. comm.), implying that parts of the Campbell Plateau may not have been significantly warmer than present.

\subsubsection{Insolation (light) intensity}

The peak of coccolithophore blooms in ODP 1120 using the MAR of $<20 \mu \mathrm{m}$ fraction shows that coccolithophore blooms occur during a minima in local insolation intensity (Fig. 8.3). Insolation at ODP 1120 reached $464 \mathrm{~W} / \mathrm{m}^{2}$ at $126 \mathrm{ka}, 53 \mathrm{~W} / \mathrm{m}^{2}$ lower than present peak summer insolation at the core site (Berger et al., 1992). During times of lower peak insolation intensity, summer is longer (Berger et al., 1992), which results in more days each year in which light levels are high enough to stimulate phytoplankton growth. The timing of the peak in MAR of $<20 \mu \mathrm{m}$ (Fig. 8.3) is due to the sedimentation rate during MIS 5e. As discussed earlier (Section 7.3), this sedimentation rate is high, and while it may be an artefact of the age model, it may also be an accurate reflection of enhanced flux to the seafloor during a period of coccolithophore blooming. The grain size record of the percent of $<20 \mu \mathrm{m}$ material (Fig. 7.7), which is not calculated using a sedimentation rate, shows the coccolithophore blooms occurring over a longer time period (110-132 ka) that spans both a maxima and minima in local insolation intensity. Blooms during low and variable insolation suggest that peak summer insolation is not a key causal factor in blooms at this core site.

\subsubsection{Water column stratification}

The $\delta^{18} \mathrm{O}$ difference between $G$. bulloides and G. inflata is used as a proxy for upper water column stratification in ODP 1120 (Fig. 8.3). For the older part of the record, from MIS 6 to MIS 7c, the oxygen isotope values of both species are similar, indicating a well mixed upper ocean, with the exception of MIS 7a which shows a greater divergence between the $\delta^{18} \mathrm{O}$ 
values (Fig. 8.3). Much of the earlier part of the record is anomalous, with $\delta^{18} \mathrm{O}$ of G. inflata more negative than G.bulloides, despite ecological evidence that it typically dwells deeper in the water column (Mortyn and Charles, 2003). Neil et al. (2004) suggest that this difference results from $G$. bulloides being displaced to an ecological niche even deeper in the water column in response to an increased production of phytoplankton. Grain size and SEM images from this study support this interpretation as they show a high accumulation of coccolithophore material at this time. Extensive blooming of coccolithophores would have assimilated much of the nutrients in the upper ocean as well as inhibiting light levels further down (Tyrell and Merico, 2004). This may have limited productivity below the surface layers and required $G$. bulloides to move to a different ecological niche in search of food. Therefore, $\Delta \delta^{18} \mathrm{O}$ between $G$. bulloides and $G$. inflata is not considered a useful stratification proxy during MIS 5e.

However, it is likely that a shallow stratified upper ocean existed during this time period due to coccolithophores requirement of such conditions to bloom (Head et al., 1998, Tyrrell and Merico, 2004, Trimborn et al., 2007, Iida et al., 2012). Neil et al. (2004) suggest stronger stratification compared to today during MIS 5, which may have been due to reduced windiness and less intense circulation on the Campbell Plateau. Pelejero et al. (2003) suggest that there was an increased occurrence of a positive Southern Oscillation Index (SOI) and La Niña conditions during MIS 5e. These conditions are hypothesized to move the belt of westerly winds south, off the Campbell Plateau (Toggweiler and Russell, 2008). Reduced windiness, or movement of the westerly wind belt to the south, is also evident in the subantarctic sector of the Atlantic Ocean, with decreased input of iron (a proxy for windblown dust) at ODP site 1090 during MIS 5e, relative to both MIS 7 and the Holocene (Martinez-Garcia et al., 2011). Evidence from the modern Southern Ocean also indicates that high productivity/ peaks in chlorophyll in subantarctic waters coincident with the shoaling of 
the mixed layer during summer (Fauchereau et al., 2011). This is consistent with the pattern on the Campbell Plateau that shows peak chlorophyll occurring during late spring to early autumn (Murphy et al., 2001) when the mixed layer is shallow (Morris et al., 2001)

\subsubsection{Productivity and nutrients}

The MAR of $\mathrm{CaCO}_{3}$ in ODP 1120 shows a significant peak during MIS 5e (Section 7.3). This peak is three times greater than the MAR of $\mathrm{CaCO}_{3}$ during the rest of the record back to MIS 7, and twice that of the MAR of $\mathrm{CaCO}_{3}$ in MIS 7. This suggests that productivity during MIS 5e was much greater than at any other time at ODP 1120 in the last 250,000 years. This value may have been artificially enhanced by close age tie point over MIS 5e. It is considerably higher than proximal core $\mathrm{Y} 9$, which shows a $\mathrm{MAR} \mathrm{CaCO}_{3}$ during MIS $5 \mathrm{e}$ of $2-3 \mathrm{~g} / \mathrm{cm}^{2} / \mathrm{kyr}$ (Carter and Manighetti, 2006). Nonetheless, it is comparable to MIS $5 \mathrm{e}$ rates of $5-6 \mathrm{~g} / \mathrm{cm}^{2} / \mathrm{kyr}$ at DSDP 594 closer to New Zealand (Carter and Manighetti, 2006). While the high MAR $\mathrm{CaCO}_{3}$ in ODP 1120 may be enhanced by close tie points in the age model, the Pukaki Rise does show increased local productivity relative to other parts of the Campbell Plateau (Murphy et al., 2001, Boyd et al., 2004, Hayward et al., 2007), and high $\mathrm{MAR} \mathrm{CaCO}_{3}$ values most likely do reflect greatly enhanced coccolith productivity during this period. The MAR of $<20 \mu \mathrm{m}$ sized material shows that the peak in $\mathrm{MAR} \mathrm{CaCO}_{3}$ is derived from coccolithophores. Smear slides of sediment deposited during MIS 5e also confirm coccolithophores as the dominant sediment component. This concentration of coccolithophore material, coupled with enhanced $\mathrm{MAR} \mathrm{CaCO}_{3}$, suggests extensive blooms in SAW on the Campbell Plateau during MIS 5e. Core SO156-55, adjacent to ODP 1120, also shows a large increase in $<63 \mu \mathrm{m}$ material during MIS 5e (Neil et al., 2004), likely to be a combination of small foraminifera and coccolithophores. However, as is also the case at P71, the potential movement of eutrophic G. bulloides to a different ecological niche, and the 
extensive and light reflecting nature of coccolithophore blooms, suggests that sub-surface productivity was likely limited.

In summary, decreased windiness, potentially warmer SSTs, and reduced circulation over the Campbell Plateau during MIS 5e promoted a stratified upper water column, favouring the blooming of coccolithophores. The blooms further enhanced stratification by creating an even warmer, bright surface layer, and restricting subsurface productivity. Peak insolation intensity is not a key causal factor in blooming at this site, as insolation varies considerably during the long period of blooming. The amplitude of insolation changes is smaller during MIS 5e than MIS 7a, and so summer would also not have been as short as during MIS 7a (Fig. 8.4).

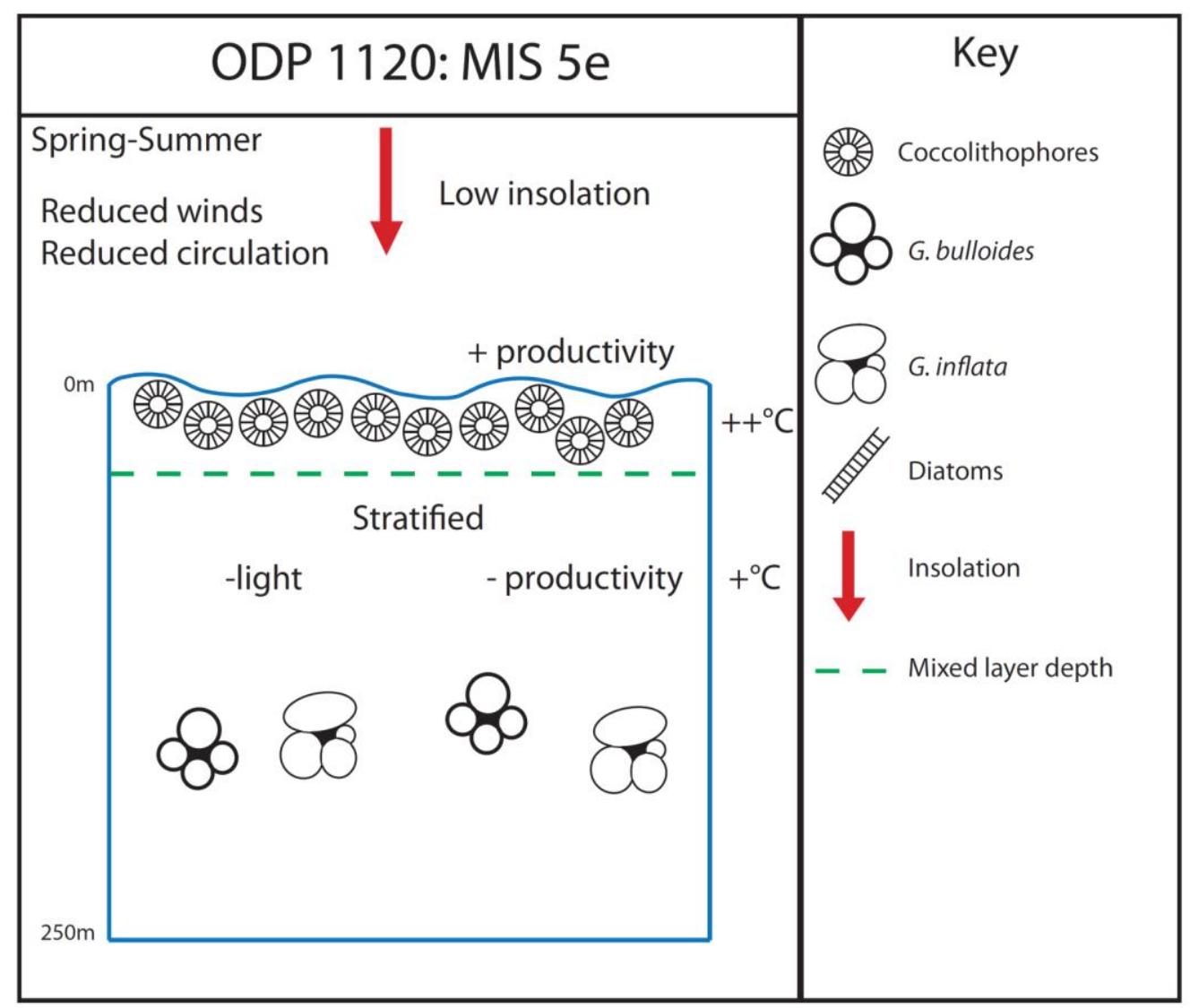

Figure 8.4: Schematic diagram of upper water column conditions during MIS 5e at ODP 1120. 


\subsection{Comparison of MIS 5e and MIS 7a at P71.}

Subtropical waters at P71 do not show significant coccolithophore productivity during MIS 5e, in contrast to the blooms shown in ODP 1120. During the blooms of P71 at MIS 7a the key causal factors are warming of the ocean from high insolation, causing thermal stratification of the upper water column. Mixing in the Tasman Front (Kawagata, 2001), may also have enhanced the supply of nutrients to the core site. Conditions during MIS 5e were less favourable for coccolithophores blooms than during MIS 7a.

Peak summer insolation at P71 during MIS 5e reached a low point at $126 \mathrm{ka}$ of $459.7 \mathrm{~W} / \mathrm{m}^{2}$, $54.3 \mathrm{~W} / \mathrm{m}^{2}$ lower than present (Berger et al., 1992). Low insolation would have resulted in less warming and thermal stratification of the surface layer, despite longer summers than MIS 7a due to the impact of obliquity and precession on insolation. Data from Cortese et al. (in prep.) and Kawagata (2001), suggest that the Tasman Inflow was not warmer during MIS 5e than present. $\mathrm{RFM}$ and $\mathrm{Mg} / \mathrm{Ca}$ G. ruber temperatures in P71 suggest that MIS 5e was not warmer than the Holocene, or the modern mean annual temperature of $19.34^{\circ} \mathrm{C}$, with the exception of a peak at $129.2 \mathrm{ka}$ of $20^{\circ} \mathrm{C}$. Thus, while SSTs were warm, low insolation would not have enhanced the temperature gradient and hence thermal stratification.

Foraminifera census counts in P71 also show a different pattern during MIS 5e compared to MIS 7a. At the peak of MIS 5e eutrophic species (dominated by G. bulloides) were abundant, and subtropical species were common. This suggests that, contrary to MIS 7a, eutrophic species did not decreased in productivity as there were not significant coccolithophores blooms. Eutrophic species then decreased as coccolithophores increased during MIS 5d. Kawagata (2001) suggests that the Tasman Inflow had intensive mixing during MIS 7 with increased phytoplankton activity. The EAC separates into the EAC southern extension and the Tasman Inflow at $31-33^{\circ} \mathrm{S}$ (Ridgway and Dunn, 2003). Mixing may therefore be the 
result of increased flow along the Tasman Inflow, at the expense of the southern EAC, a process that occurs when wind stress curl over the South Pacific is weak (Ridgway and Hill, 2009, Hill et al., 2011). This suggests that the surface source waters for P71 were well mixed, and so potentially contained higher nutrient concentrations, and were more productive during MIS 7a. Kawagata (2001) does not find evidence for an increased mixing field in the Tasman Inflow during MIS 5e. Comparable temperatures between MIS 7a and MIS 5e, but low insolation and less enhanced mixing and productivity in source waters in MIS 5e appear to have resulted in lower coccolithophore abundances (Figs. 8.2 and 8.5). This is in contrast to ODP 1120 where significant blooming occurs during MIS 5e.

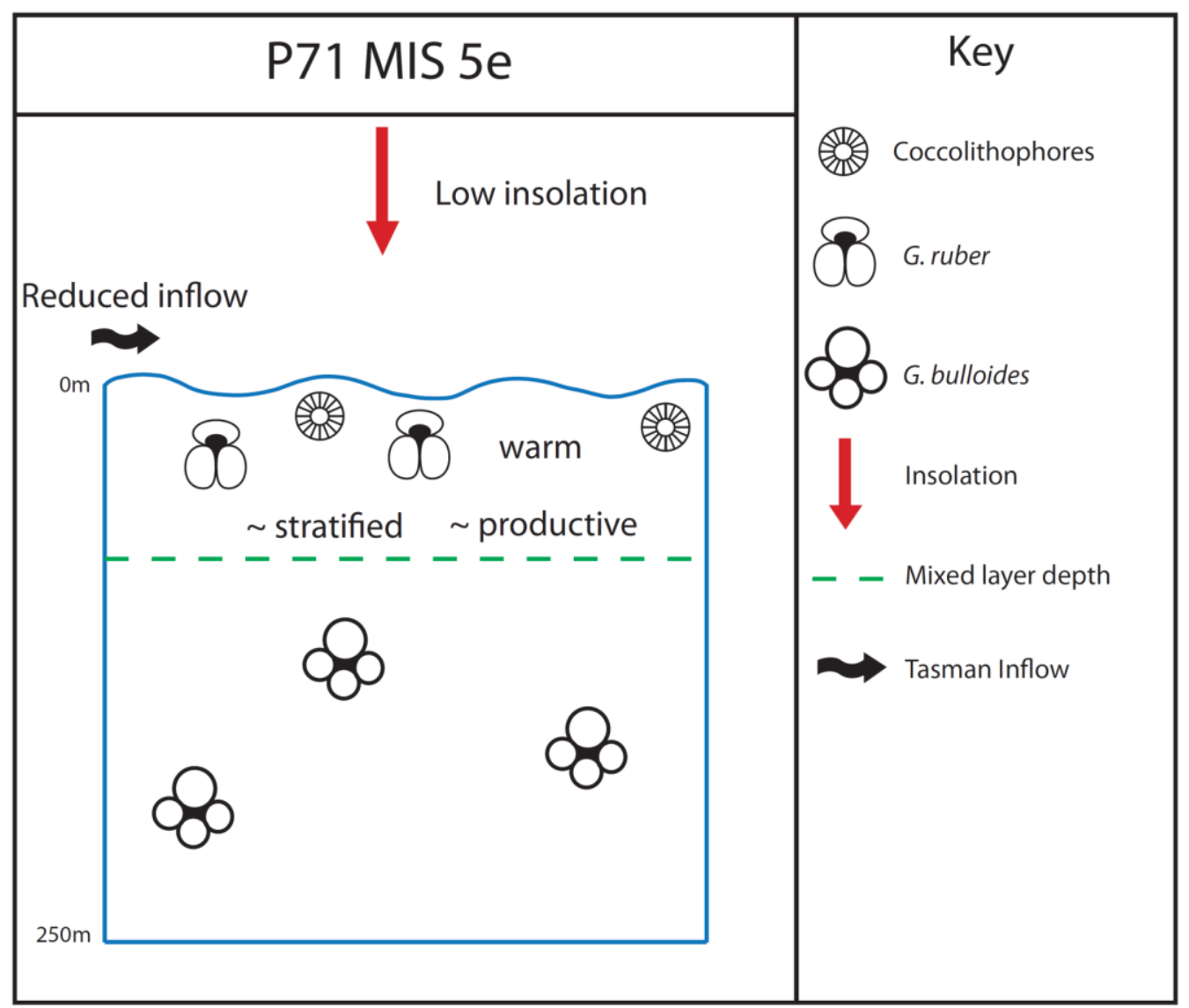

Figure 8.5: Schematic diagram of upper water column conditions during MIS 5e at P71. 


\subsection{Comparison of MIS 5e and MIS 7a at ODP 1120}

High insolation was an important factor in the blooms of MIS 7a at P71, as intense light levels enhanced thermal stratification favouring bloom formation. However the lack of blooms during the equivalent time at ODP 1120 suggests that insolation was not the prime causal factor for bloom formation, and that in SAW, other environmental factors predominate.

Peak summer insolation at ODP 1120 during MIS 7a, was $560 \mathrm{~W} / \mathrm{m}^{2}$, higher than at core site P71, and higher than present by $43 \mathrm{~W} / \mathrm{m}^{2}$ (Berger et al., 1992), but there was no major bloom at ODP 1120. This apparent absence of insolation control is supported by summer insolation intensities lower than today (and MIS 7a) during the long period of enhanced coccolith productivity during MIS 5. The fine fraction in ODP 1120 during MIS 7a is only $40 \%$ of the total grain size, compared to $60-70 \%$ during MIS 5. SEM images show it consists of a range of coccolithophore species of varying sizes, and, unlike MIS 1 and MIS 5, this sample also contains common broken frustules of diatom Thalassiothrix spp (Fig. 7.13). Smear slides of the $<63 \mu \mathrm{m}$ fraction from ODP 1120 also support the presence of diatoms throughout MIS 7 . In contrast, smear slides from P71 show no diatoms. Maximum abundances of Thalassiothrix spp. in the modern ocean occur north of the wintertime sea ice limit at $\sim 60^{\circ} \mathrm{S}$ (Comiso, 2008) and decrease in abundance north of the SAF (Crosta et al., 2005). Thalassiothrix spp. tolerates a wide range of temperatures, with maximum occurrences between $2-14^{\circ} \mathrm{C}$ (Crosta et al., 2005). The lack of diatoms during MIS 1 and MIS 5 suggest that MIS 7a was more favourable for their productivity, and they successfully competed with coccolithophores for light and nutrients.

Oxygen isotopes at ODP 1120 are not an accurate record of stratification changes, as high surface productivity appears to affect the ecological niche of $G$. bulloides. The presence of 
diatoms suggests that silicate was an available nutrient during MIS 7. Stratification prevents upwelling of silicate-bearing waters in areas of low surface silicate concentrations (Iida et al., 2012). Modern conditions over the Campbell Plateau show that the water column is well mixed during winter, allowing nutrients to mix throughout the upper water column making them available to phytoplankton (Morris et al., 2001). Productivity in SAW is co-limited by light and iron, and peaks from late spring through to autumn (King and Howard, 2001, Murphy et al., 2001, Nodder and Northcote, 2001). When the mixed layer shallows in spring and light levels increase, then phytoplankton are able to take advantage of high nutrient abundances (Morris et al., 2001). Coccolithophore blooms usually follow diatoms, once nutrients, especially silicate, have been depleted and light levels are high (Tyrrell and Merico, 2004, Zondervan, 2007, Holligan et al., 2010). Summer is shorter when insolation is high, and the peak in insolation during MIS 7a would have coincided with a shorter growing season (Berger et al., 1992). With this in mind, coccolithophores may have been disadvantaged by high insolation at higher latitudes in MIS 7a, resulting in a shorter growing season for coccolithophores once diatoms had depleted surface silicate supplies.

Carbonate concentrations during MIS 7a were slightly lower than other parts of the core, with values of between $85-90 \%$. This suggests that if coccolithophore productivity was reduced in favour of biosiliceous diatoms, foraminiferal productivity was still high enough to maintain an overwhelming high carbonate content. This may be due to deeper waters over the Campbell Plateau being only slightly higher in silicate than surface waters (WOCE, http://www.ewoce.org/), so while upwelling allows some silicate to be available for diatoms, it is limited, and carbonate productivity still dominates. Biogenic silica records from around Antarctica show high siliceous productivity attributed to high insolation; MIS 7a in fact coincides with some of the highest values of siliceous productivity there over the last 0.9 million years (Grobe and Mackensen, 1992, Cortese and Gersonde, 2008, Hillenbrand et al., 
2009). Unfortunately there are no siliceous productivity records for the Campbell Plateau, possibly due to the dominance of carbonate productivity (80-100\% $\mathrm{CaCO}_{3}$, Section 7.2).

Another process that could have enhanced diatom productivity in MIS 7a is the input of ironrich material. In high macro-nutrient/ low chlorophyll areas such as SAW, changes in the iron supply can directly affect primary productivity and species composition (Boyd et al., 1999, Calvo et al., 2004, Jickells et al., 2005, Mackie et al., 2008). Iron is an essential micronutrient used in photosynthesis, respiration and nitrogen fixation, and so iron supply can often be a limiting factor on phytoplankton growth (Jickells et al., 2005). Diatoms have a high requirement for iron compared with coccolithophores, and so enhanced supply of iron may favour their productivity (Zondervan, 2007, Holligan et al., 2010). Calvo et al. (2004) find evidence for enhanced siliceous productivity close to Australia in response to increased dust inputs from the continent, especially during glacial periods. However, the seasonality of iron input would also have to coincide with other environmental factors such as sufficient light, and available silicate, and there is debate over the effectiveness of dust iron input in stimulating phytoplankton blooms (Boyd and Mackie, 2010). The dominant input of iron into the oceans is from aeolian dust transport and hydrothermal sources, but glacial particulates can play a role too, usually closer to land as the particulates melt out of the ice (Jickells et al., 2005, Tagliabue et al., 2010).

The most prominent source of dust to SAW is from Australia, and dust plume trajectories have been modelled to show that dust from the Australian continent can reach the Campbell Plateau (McGowan et al., 2000). Records of aeolian derived dust from the Tasman Sea show no enhanced dust input during MIS 7a (Hesse, 1994, Calvo et al, 2004). However, IRD records from the Campbell Plateau show MIS 7a to have the highest IRD abundance during the late Pleistocene (Section 4.6) (Carter et al., 2002). Icebergs can carry nanoparticles of bioavaliable iron which is released upon melting (Raiswell et al., 2008). Free drifting 
icebergs in the Weddell Sea are associated with locally enhanced productivity, suggesting that icebergs can impact the productivity of the pelagic system (Smith et al., 2007). Raiswell at al. (2008) determined that current fluxes of iceberg-derived bioavaliable iron is comparable to iron from aeolian dust in the Southern Ocean, and that an increase in iceberg production has the capacity to increase phytoplankton productivity. While these studies have focused on areas south of $60^{\circ} \mathrm{S}$, it is conceivable that the enhanced IRD during MIS 7a could have increased iron abundance at ODP 1120, and increased the productivity of diatoms.

Cores in SAW waters show temperatures were cooler than present by $\sim 1-3^{\circ} \mathrm{C}$ during MIS $7 \mathrm{a}$ (Pahnke et al., 2003, Hayward et al., 2008, Lüer et al., 2009, Marr et al., 2011). Cooler waters at ODP 1120 potentially did not respond to insolation with any surface warming, preventing the significant thermal stratification that occurs at ODP 1120 during MIS 5e and at P71 in MIS 7a (Figs. 8.4 and 8.6).

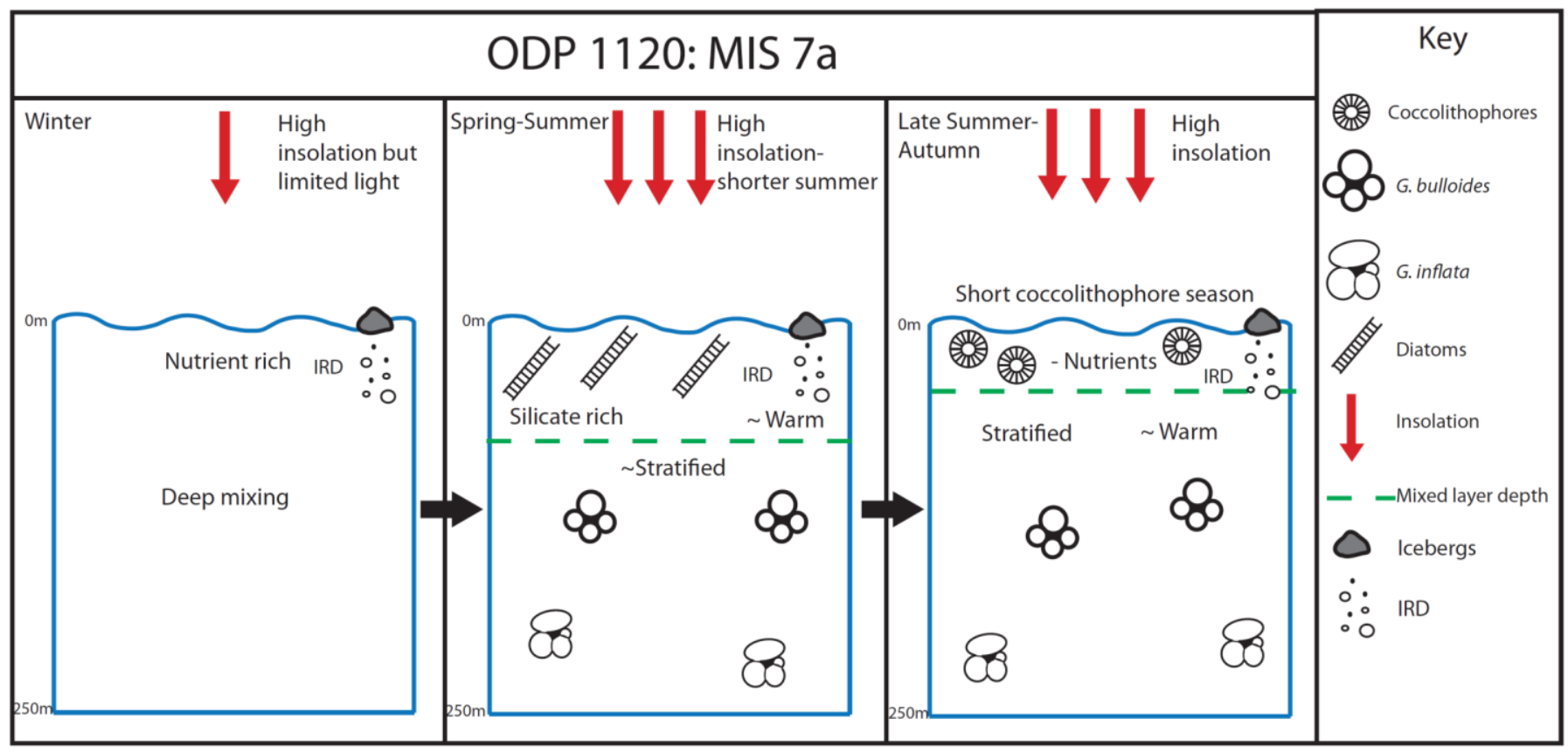

Figure 8.6: Schematic diagram of upper water column conditions during MIS 7a at ODP 1120. 


\subsection{Future impacts}

As $\mathrm{CO}_{2}$ increases in the surface ocean, the concentration of $\mathrm{CO}_{3}{ }^{2-}$, a key building block for calcifying organisms, decreases (Rost and Riebesell, 2004, Iglesias-Rodriguez et al., 2008, Beaufort et al., 2011). The response of coccolithophores is debated; however paleoclimatic studies and culture experiments, coupled with some modern observations suggest that certain species and strains, such as E. huxleyi, may be resilient to $\mathrm{CO}_{2}$ increases (Iglesias-Rodríguez et al., 2008, Beaufort et al., 2011, Müller et al., 2012). As coccolithophores are also fast growers and adapters they may evolve to be well suited to high $\mathrm{CO}_{2}$ levels (Rost and Riebesell, 2004, Lohbeck et al., 2012). An increase in production of coccolithophores may impact on the carbon system, as they contribute to both the biological pump and the carbonate counter pump. However, further research is required to determine how this may affect the ocean carbon system.

By comparing an interglacial with significant coccolithophore blooms, to one without significant blooms at subtropical and subantarctic core sites, some insights are gained regarding the relative importance of different ocean conditions favourable for blooms. Increased flow of warm, micro-nutrient rich waters from the Tasman Inflow flowing over the P71 core site is a contributing factor. High insolation also seems to be an important factor in thermally stratifying the water column. However, high coccolithophore abundances at MIS 5d and MIS 1/2 during times of marginal insolation suggest that while it potentially contributed to the blooms at MIS 7a, it is not an absolute prerequisite for coccolithophore blooms. Blooms at P71 require a mechanism which creates a stratified, warm and nutrientrich upper water column. At ODP 1120 warmer and more highly stratified water, resulting from reduced windiness and circulation during MIS 5e, are key components to times of blooming as they allow coccolithophores to outcompete diatoms. 
Currently coccolithophore productivity is moderate at each core site, but with ocean conditions undergoing change (Roemmich et al., 2007, Hill et al., 2009), coccolithophore productivity may change in the future. There has already been a response from coccolithophores to warming SSTs in other parts of the Southern Ocean with evidence of a southward migration of E. huxleyi (Cubillos et al., 2007). Current trends and model projections suggest that blooming may increase in SAW and higher latitudes, and decrease closer to the equator (Iglesias-Rodríguez et al., 2002, Smyth et al., 2004).

The Tasman Inflow has been suggested to have been more intensely mixed during MIS 7 (Kawagata, 2001). The intensity of the Tasman Inflow and surrounding eddies are dependent on the strength of the wind stress curl (the gradient of wind stress on the surface ocean) over the South Pacific (Hill et al., 2011). Wind stress curl varies on quasi-decadal timescales, and affects the transport pathways of the EAC (Hill et al., 2011). When the wind stress curl is greater, most of the EAC's flow continues south, and volume transport within the Tasman Inflow is slightly weaker (Cai et al., 2005, Ridgway and Hill, 2009, Hill et al., 2011). This is reversed when the wind stress curl is weaker, flow along the Tasman Front increases, with increased eddies and mixing of the upper water column (Ridgway and Hill, 2009, Hill et al., 2011), implying enhanced supply of nutrients to the surface. However, while wind stress curl varies on a decadal cycle, there is an overall trend towards a more intensive wind stress curl due to a poleward shift in the circumpolar westerly winds over the last 50 years (Roemmich et al., 2007, Ridgway and Hill, 2009). This has led to enhanced flow along the EAC southern extension, and weaker flow along the Tasman Front (Hill et al, 2008, Ridgeway and Hill, 2009). As anthropogenic $\mathrm{CO}_{2}$ increases, a trend towards a positive Southern Annular Mode around Antarctica and the Southern Ocean is expected to continue (Ridgway and Hill, 2009). As the core of the westerly winds intensifies and migrates poleward, the South Pacific Gyre and South Pacific wind stress curl also intensify (Ridgway and Hill, 2009). During MIS 5e 
and MIS 7c $\mathrm{CO}_{2}$ was comparable and slightly higher than preindustrial times (Petit et al., 1999). Significant coccolithophore blooms were absent from P71 during these times, and may indicate that the South Pacific wind stress curl was higher during the peaks of the interglacials, and the Tasman Inflow was less active. During the parts of the interglacials with reduced $\mathrm{CO}_{2}$ levels such as MIS 7a, MIS 5d or even the MIS $1 / 2$ transition, the wind stress curl may have been weaker, and there may have been more transport in the Tasman Inflow. Current trends suggest that flow along the Tasman Inflow will continue to lessen, suggesting waters reaching the core site will be less mixed, and the surface waters above P71 may not be as productive as they were during MIS 7a.

Present summer insolation intensity at $33^{\circ} \mathrm{S}$ is lower by $39 \mathrm{~W} / \mathrm{m}^{2}$ than during MIS 7a (Berger et al., 1992). Lower insolation, and lower light levels, would not enhance warming of the surface ocean and stratification to the same degree as it was during the higher insolation of MIS 7a. While warmer ocean temperatures have been shown to not be a prime causal factor for coccolithophore blooms, they affect the thermal structure of the upper ocean as well as the wind regimes that control upper ocean mixing. The oceans around New Zealand have been shown to be warming slightly over the last century (Folland and Salinger, 1995, Sutton et al., 2005). However, without the added effect of high insolation and the attendant changes in light intensity and windiness, coccolithophore blooms may not prevail at the P71 core site.

At ODP 1120, stratification of the water column caused by reduced circulation and windiness appears to be the key causal factor in the blooms of MIS 5e. At present, the circulation over the Campbell Plateau is relatively quiescent, compared to the intensity of the ACC around the Plateau's margins (Morris et al., 2001). Some ill-defined flow is apparent on the Campbell Plateau, including an anticyclonic gyre around the Pukaki Rise and a NE inflow from the ACC through Pukaki Saddle (Morris et al., 2001). The plateau is in the path of the strong westerly winds, currently between $\sim 45-50^{\circ} \mathrm{S}$ (Toggweiler and Russell, 2008). However, the 
core of the westerly wind belt has intensified and migrated south, and now sits directly above the ACC, causing the ACC to strengthen (Toggweiler and Russell, 2008), and become more turbulent (Böning et al., 2008). East of the Campbell Plateau, Fernandez (Unpublished MSc thesis) found that the confluence of the ACC with the STF, and associated eddy activity are intensifying. The impact of such changes on the Campbell Plateau is open to speculation. Two potential outcomes are possible. The southern migration of the westerly winds may result in a reduction of windiness over the Campbell Plateau, as is suggested during MIS 5e by Neil et al. (2004). Removing some of the wind stress could result in reduced circulation, and enhanced stratification. On the other hand the intensification of the ACC and associated eddies may impinge on the Campbell Plateau, resulting in increased input of cooler waters from the SAF jets of the ACC, and potentially increase mixing over the whole plateau, or increase mixing at the boundary of the plateau while further isolating the plateau interior. The former suggestion would result in conditions comparable to MIS 5e, and enhanced coccolithophore blooming over the Pukaki Rise, and the rest of the Campbell Plateau could result. A potential increase in coccolithophore blooming at subantarctic ODP 1120, but not at subtropical P71 is in line with modelled projections of the changing distribution of coccolithophore blooming in the future. 


\section{CONCLUSIONS}

This study aimed to reconstruct the environmental conditions, and identify the causal factors associated with coccolithophore blooms at core sites in subtropical (P71) and subantarctic (ODP 1120) waters during MIS 5e and MIS 7a. In particular, the timing of the bloom during MIS 7a at P71 appears unusual, as it occurs during what is thought to be a relatively cool and little-studied interglacial. Therefore additional effort was put in to compiling a detailed reconstruction of ocean conditions throughout MIS 7 in the Southwest Pacific. These show that during both MIS 7a and 7c interstadials the temperature gradient across the STF on Chatham Rise was larger than today, and the STF appeared to have moved to a more northerly location in the Tasman Sea. Temperatures in the Tasman Inflow were comparable to modern in MIS 7a, but cooler in MIS 7c.

A robust method was determined for quantifying changes coccolithophores abundance over time, using sediment grain size. Relative to today, substantially enhanced coccolithophore productivity occurred in MIS 7a, and to a slightly lesser extent in MIS 1/2 and MIS 5d at P71, but not during MIS 5e. At ODP 1120, significant blooms occurred in MIS 5e, but not during MIS 7a. The following environmental factors were calculated or reconstructed for each of these time periods: irradiance, SST, water column stratification/mixing and nutrient availability. It appears that no one factor is solely responsible for causing blooms, and instead it is the combination and interactions between different environmental processes that create favourable conditions for enhanced coccolithophore productivity at these locations. In P71 blooms during MIS 7a are inferred to be the result of a peak in summer insolation combining with regionally warm SSTs to produce a thermally stratified surface ocean with higher than present irradiance levels. Surface waters carried by the Tasman Inflow are also thought to have been well-mixed during this time period. These factors promoted blooms, which 
generated a positive feedback mechanism, enhancing stratification due to their albedo effect, restricting light and nutrients to subsurface waters and limiting the productivity of eutrophic foraminifera. However in MIS 5e, a summer insolation minima, and less mixed waters within the Tasman Inflow, resulted in reduced thermal stratification and consequently no significant coccolithophore blooms.

At ODP 1120, greatly enhanced coccolithophore productivity during MIS 5e is inferred to be the result of decreased windiness, potentially warmer SSTs and reduced ocean circulation over the Campbell Plateau. This resulted in highly stratified surface water, encouraging coccolithophore blooms and reduced subsurface productivity, in spite of a summer insolation minima. However, in MIS 7a the orbital geometry that caused high summer insolation intensity also caused a reduced duration of summer and this may have disadvantaged coccolithophores by limiting their growing season. More diatoms were present in MIS 7a than MIS 1 and MIs 5e, and despite still only being a minor component of the sediment, diatoms may have competed with coccolithophores for some of the light and nutrients. Cooler waters may also have not responded to high summer insolation with any enhanced thermal stratification.

The factors that are inferred to have caused blooms at each core site in the past can be compared to modern oceanic trends in the Southwest Pacific. At P71, insolation and wellmixed source waters from the Tasman Inflow appear to be the key factors promoting blooms. Insolation is considerably lower at present than during MIS 7a so will not contribute to enhancing thermal stratification on centennial timescales. Flow along the EAC is expected to increase with a greater wind stress curl over the South Pacific, at the expense of flow along the Tasman Inflow. This will result in less well-mixed waters reaching the site. Current, and predicted future, conditions can be compared to MIS 5e when no significant coccolithophores blooms occurred at P71. At ODP 1120 the key causal factors for blooms are reduced 
windiness and circulation coupled with potentially warmer waters resulting in enhanced thermal stratification. There are two possible scenarios for changing ocean conditions on the Campbell Plateau in the future. An intensified ACC may impinge on the plateau, resulting in cooler waters and increased circulation, or the plateau may become increasingly isolated as westerly winds move south. This would result in lessened winds and reduced circulation, with conditions comparable to when significant blooms occurred during MIS 5e.

By comparing conditions that favoured coccolithophore blooms in subtropical and subantarctic waters in the past, some interpretations have been made regarding the relative importance of factors in causing blooms at each site, and what this means for coccolithophores response to future climate change. From this, it can be proposed that blooms may not become more prominent at P71 in the future, but could increase at ODP 1120. An increase in coccolithophore blooms could have a significant impact the ocean system, as they promote stratification resulting in high productivity at the surface, but decreased subsurface productivity. 


\section{FUTURE WORK}

This study has shown that there are a number of areas which would benefit from further research. To better determine what may have caused coccolithophore blooms in the past, we have to better understand what is causing blooms at present. Therefore, more modern studies on coccolithophore distributions, blooms and ecology, as well as modelling and lab-based physiological studies are required. A more comprehensive set of high resolution cores around the Southwest Pacific Ocean would give a clearer insight into whether these glacial/interglacial patterns in coccolithophore productivity are peculiar to the Campbell Plateau and North East New Zealand, or can be traced further afield. Conditions during MIS 7 could be better defined by increasing the spatial coverage and number of cores that extend to this time period, particularly cores that contain SST and productivity records. Core records that extended back through older interglacials would also help to clarify if the conditions which favour blooms at different core sites in MIS 7 and MIS 5 are consistent back through time. A more globally extensive study of the conditions that have favoured blooms in the past would enable further conclusions to be made on how coccolithophores are likely to respond to changing environmental conditions, and the impact that this might have on the ocean carbon system. 


\section{REFERENCES}

Andruleit, H., U. von Rad, A. Bruns, and V. Ittekkot (2000), Coccolithophore fluxes from sediment traps in the northeastern Arabian Sea off Pakistan, Marine Micropaleontology, 31, 45-64.

Balch, W.M. (2004), Re-evaluation of the physiological ecology of coccolithophores, in Coccolithophores From Molecular Processes to Global Impact, edited by H.R. Thierstein and J.R. Young, pp. 165-191, Springer-Verlag Berlin Heidelberg, Germany.

Barrows, T.T., S. Juggins, P. De Deckker, E. Calvo, and C. Pelejero (2007), Long-term sea surface temperature and climate change in the Australian-New Zealand region, Paleoceanography, 22, PA2215, doi:10.1029/2006PA001328.

Baumann K.-H., B. Böckel, and M. Frenz (2004), Coccolith contribution to Southern Atlantic carbonate sedimentation, in Coccolithophores From Molecular Processes to Global Impact, edited by H.R. Thierstein and J.R. Young, pp. 367-403, Springer-Verlag Berlin Heidelberg, Germany.

Bé, A.W.H., and D.S. Tolderlund (1971) Distribution and ecology of living planktonic foraminifera in surface waters of the Atlantic and Indian Oceans, in The Micropalaeontology of Oceans, edited by B.M. Funnell and W.R. Riedel, Cambridge University Press, New York, 105-150.

Bé, A.W.H., C. Hemleben, O.R. Anderson, M. Spindler, J. Hacunda, and S. Tuntivate-Choy (1977), Laboratory and field observations of living planktonic foraminifera, Micropaleontology, 23(2), 155-179.

Beaufort, L., I. Probert, T. de Garidel-Thoron, E.M. Bendif, D. Ruiz-Pino, N. Metzl, C. Goyet, N. Buchet, P. Coupel, M. Grelaud, B. Rost, R.E.M. Rickaby, and C. de Vargas 
(2011), Sensitivity of coccolithophores to carbonate chemistry and ocean acidification, Nature, 476, 80-83.

Berger, A., and M.F. Loutre (1992), Astronomical solutions for paleoclimate studies over the last 3 million years, Earth and Planetary Science Letters, 111, 369-382.

Berger, A., M.F. Loutre, F. Kaspar, and S.J. Lorenz (2007), Insolation during Interglacial, in The Climate of Past Interglacials, Developments in Quaternary Sciences, 7, 13-27.

Bijma, J., W.W. Faber Jr., and C. Hemleben (1990), Temperature and salinity limits for growth and survival of some planktonic foraminifers in laboratory cultures, Journal of Foraminiferal Research, 20(2), 95-116.

Boeckel, B., K.-H. Baumann, R. Henrich, and H. Kinkel (2006), Coccolith distribution patterns in South Atlantic and Southern Ocean surface sediments in relation to environmental gradients, Deep-Sea Research, 53, 1073-1099.

Bollmann, J. (1997), Morphology and biogeography of Gephyrocapsa coccoliths in Holocene sediments, Marine Micropaleontology, 29, 319-350.

Bolton A, J.A. Baker, G.B. Dunbar, L. Carter, E.G.C. Smith, and H.L. Neil (2011), Environmental versus biological controls on $\mathrm{Mg} / \mathrm{Ca}$ variability in Globigerinoides ruber (white) from core top and plankton tow samples in the southwest Pacific Ocean, Paleoceanography, 26, PA2219, dio:10.1029/2010PA001924.

Böning, C.W., A. Dispert, M. Visbeck, S.R. Rintoul, and F.U. Schwarzkopf (2008), The response of the Antarctic Circumpolar Current to recent climate change, Nature Geoscience, 1, 864-869. 
Bostock, H.C., B.W. Hayward, H.L. Neil, K.I. Currie, and G.B. Dunbar (2011), Deep-water carbonate concentrations in the southwest Pacific, Deep Sea Research Part 1: Oceanographic Research Papers, 58 (1), 72-85.

Boyd, P., J. LaRoche, M. Gall, R. Frew, and R.M.L. McKay (1999), Role of iron, light, and silicate in controlling algal biomass in subantarctic waters SE of New Zealand, Journal of Geophysical Research, 104 (C6), 13,395-13,408.

Boyd, P.W., G. McTainsh, V. Sherlock, K. Richardson, S. Nichol, M. Ellwood, and R. Frew (2004), Episodic enhancement of phytoplankton stocks in New Zealand subantarctic waters: Contribution of atmospheric and oceanic iron supply, Global Biogeochemical Cycles, 18, GB1029, doi:10.1029/2002GB002020.

Boyd, P.W., D.S. Mackie, and K.A. Hunter (2010), Aerosol iron deposition to the surface ocean- Modes of iron supply and biological responses, Marine Chemistry, 120 (1-4), 128-143.

Bradford, J.M., R.A. Heath, F.H. Chang, and C.H. Hay (1982), The effect of warm-core eddies on oceanic productivity off northeastern New Zealand, Deep-Sea Research, 29 (12A), 1501-1516.

Bradford-Grieve, J., R. Murdoch, M. James, M. Oliver, and J. McLeod (1998), Mesozooplankton biomass, composition, and potential grazing pressure on phytoplankton during austral winter and spring 1993 in the Subtropical Convergence region near New Zealand, Deep-Sea Research I, 45, 1709-1737.

Bradford-Grieve, J.M., P.K. Probert, S.D. Nodder, D. Thompson, J. Hall, S. Hanchet, P. Boyd, J. Zeldis, A.N. Baker, H.A. Best, N. Broekhuizen, S. Childerhouse, M. Clark, M. Hadfield, K. Safi, and I. Wilkinson (2003), Pilot trophic model for subantarctic water 
over the Southern Plateau, New Zealand: a low biomass, high transfer efficiency system, Journal of Experimental Marine Biology and Ecology, 289, 223-262.

Brand, L.E., and R.R.L. Guillard (1981), The effects of continuous light and light intensity on the reproduction rates of twenty-two species of marine phytoplankton, Journal of Experimental Marine Biology and Ecology, 50 (2-3), 119-132.

Brand, L.E., W.G. Sunda, and R.R.L. Guillard (1983), Limitation of marine phytoplankton reproductive rates by zinc, manganese, and iron, Limnology and Oceanography, 28 (6), 1182-1198.

Breiman, L. (2001), Random Forests, Machine Learning, 45, 5-32.

Broecker, W., and E. Clark (2009), Ratio of coccolith $\mathrm{CaCO}_{3}$ to foraminfera $\mathrm{CaCO}_{3}$ in the late Holocene deep sea sediments, Paleoceanography, 24, PA3205, doi:10.1029/2009PA001731.

Bruland, K.W., and M.C. Lohan (2003), 6.02- Controls of Trace Metals in Seawater, Treatise on Geochemistry, 6, 23-47.

Brummer, G.J.A., and A.J.M. van Eijden (1992), "Blue-ocean" paleoproductivity estimates from pelagic carbonate mass accumulation rates, Marine Micropaleontology, 19 (1-2), 99-117.

Burns, D.A. (1972), The latitudinal distribution and significance of calcareous nannofossils in the bottom sediments of the South-west Pacific Ocean (Lat. $15-55^{\circ} \mathrm{S}$ ) around New Zealand, Oceanography of the South Pacific, 221-228. 
Bussell, M.R., and B. Pillans (1997), Vegetational and climatic history during oxygen isotope stage 7 and early stage 6, Taranaki, New Zealand, Journal of the Royal Society of New Zealand, 27 (4), 419-438.

CARS SST reconstruction (2009), http://www.marine.csiro.au/ dunn/cars2009/

Cai, W., G. Shi, T. Cowan, D. Bi, and J. Ribbe (2005), The response of the Southern Annular Mode, the East Australian Current, and the southern mid-latitude ocean circulation to global warming, Geophysical Research Letters, 32 (23), 1-4.

Calvo, E., C. Pelejero, G.A. Logan, and P. De Deckker (2004), Dust-induced changes in phytoplankton in the Tasman Sea during the last four glacial cycles, Paleoceanography, 19, PA2020, doi:10.1029/2003PA000992.

Carter, L., H.L. Neil, and I.N. McCave (2000), Glacial to interglacial changes in noncarbonate and carbonate accumulation in the SW Pacific Ocean, New Zealand, Palaeogeography, Palaeoclimatology, Palaeoecology, 162 (3-4), 333-356.

Carter L., H.L. Neil, and L. Northcote (2002), Late Quaternary ice rafting events in the SW Pacific Ocean off eastern New Zealand, Marine Geology, 191, 19-35.

Carter, L., and B. Manighetti (2006), Glacial/interglacial control of terrigenous and biogenic fluxes in the deep ocean off a high input, collisional margin: A 139 kyr-record from New Zealand, Marine Geology, 226 (3-4), 307-322.

Carter L., B. Manighetti, G. Ganssen, and L. Northcote (2008), Southwest Pacific modulation of abrupt climate change during the Antarctic Cold Reversal- Younger Dryas, Palaeogeography, Palaeoclimatology, Palaeoecology, 260 (1-2), 284-298.

Carter, R.M., I.N. McCave, C. Richter, L. Carter, and the Shipboard Party (1999), Leg 181 Initial Reports of the Ocean Drilling Program, College Station Texas. 
Chappell J., and N.J. Shackleton (1986), Oxygen isotopes and sea level, Nature, 324, 137140.

Chiswell, S.M. (2011), Annual cycles and spring blooms in phytoplankton: don't abandon Sverdrup completely, Marine Ecology Progress Series, 443, 39-50.

Clark P.U., and N.G. Pisias (2000), Interpreting iceberg deposits in the deep sea, Science, 290 (5489), 51-52.

Comiso, J.C. (2008), Large scale characteristics and variability of global sea ice cover, in Sea Ice: An introduction to its physics, biology, chemistry and geology, edited by D.N. Thomas, and G.S. Dieckmann, Blackwell Science Ltd, Oxford, UK, doi:10.1002/9780470757161.ch4.

Congdon P. (2001), Bayesian Statistical Modelling. Wiley Series in Probability and Statistics, John Wiley and Sons, Chichester. 529pp.

Cortese G., and R. Gersonde (2008), Plio/Pleistocene changes in the main biogenic silica carrier in the Southern Ocean, Marine Geology, 252, 100-110.

Cortese, G., G. Dunbar, G. Scott, L. Carter, H. Bostock, M. Bowen, H. Neil, M. Crundwell, B.W. Hayward, J.I. Martinez, and A. Sturm (in prep.), Southwest Pacific Ocean response to a warmer world- insights from Marine Isotope Stage 5e.

Cros, L., and J.-M. Fortuña (2002), Atlas of northwestern Mediterranean coccolithophores, Scientia Marina, 66 (Suppl. 1), 7-182.

Crosta, X., O. Romero, L.K. Armand, and J-J Pichon (2005), The biography of major diatom taxa in Southern Ocean sediments: 2. Open ocean related species, Palaeogeography, Palaeoclimatology, Palaeoecology, 223 (1-2), 66-92. 
Crundwell, M., G. Scott, T. Naish, and L. Carter (2008), Glacial-interglacial ocean climate variability from planktonic foraminifera during the Mid-Pleistocene transition in the temperate Southwest Pacific, ODP Site 1123, Palaeogeography, Palaeoclimatology, Palaeoecology, 260, 202-229.

Cubillos, J.C., S.W. Wright, G. Nash, M.F. de Salas, B. Griffiths, B. Tilbrook, A. Poisson, and G.M. Hallegraeff (2007), Calcification morphotypes of the coccolithophorid Emiliania huxleyi in the Southern Ocean: Changes in 2001 to 2006 compared to historical data, Marine Ecology Progress Series, 348, 47-54.

d'Orbigny, A.D. (1826), Tableau méthodique de la classe des Céphalopodes, Annales des Sciences Naturalles, Paris, 1 (7), 96-314, plates 10-17.

d'Orbigny, A.D. (1839a), Histoire physique, politique et naturelle de l'Ile de Cuba, vol. 8, Foraminifères, edited by R. de la Sagra, pp. 1-224, Paris.

D’Orbigny, A.D. (1839b), Foraminifères des Iles Canaries, in Histoire naturelle des Iles Canaries 2, part 2, edited by P. Barker-Webb, and S. Berthelot, Paris, 119-146.

Dekens, P.S., D.W. Lea, D.K. Pak, and H.J. Spero (2002), Core top calibration of Mg/Ca in tropical foraminifera: Refining paleotemperature estimation, Geochemistry, Geophysics, Geosystems, 3 (4), 1022, doi:10.1029/2001/GC000200.

Dudley, W.C., and C.S. Nelson (1994), The influence of non-equilibrium isotope fractionation on the Quaternary calcareous nannofossil stable isotope signal in the southwest Pacific Ocean, DSDP Site 594, Marine Micropaleontology, 24 (1), 3-27.

Dutton, A., E. Bard, F. Antonioli, T.M. Esat, K. Lambeck, and M.T. McCulloch (2009), Phasing and amplitude of sea-level and climate change during the penultimate interglacial, Nature Geoscience, 2, 355-359. 
Elderfield, H., M, Vautravers, and M. Cooper (2002), The relationship between shell size and $\mathrm{Mg} / \mathrm{Ca}, \mathrm{Sr} / \mathrm{Ca}, \delta^{18} \mathrm{O}$, and $\delta^{13} \mathrm{C}$ of species of planktonic foraminifera, Geochemistry, Geophysics, Geosystems, 3 (8), 1052, doi:10.1029/2001GC000194.

Ellwood, M.J. (2004), Zinc and cadmium speciation in subantarctic waters east of New Zealand, Marine Chemistry, 87 (1-2), 37-58.

Fauchereau, N., A. Tagliabue, L. Bopp, and P.M.S. Monteiro (2011), The response of phytoplankton biomass to transient mixing events in the Southern Ocean, Geophysical Research Letters, 38, L17601, doi:10.1029/2011GL048498.

Fernandez D. (2012), Do winds control the confluence of subtropical and subantarctic surface waters east of New Zealand? (M.Sc. Thesis), Victoria University of Wellington.

Flores, J-A., M. Marino, F.J. Sierro, D.A. Hodell, and C.D. Charles (2003), Calcareous plankton dissolution pattern and coccolithophore assemblages during the last $600 \mathrm{kyr}$ at ODP Site 1089 (Cape Basin, South Atlantic): paleoceanographic implications, Palaeogeography, Palaeoclimatatology, Palaeoecology, 196 (3-4), 409-426.

Folland, C.K., and M. J. Salinger (1995), Surface temperature trends and variations in New Zealand and the surrounding ocean, 1871-1993, International Journal of Climatology, $15(11), 1195-1218$.

Frenz M., K.-H. Baumann., B. Boeckel, R. Höppner, and R. Henrich (2005), Quantification of foraminifer and coccolith carbonate in South Atlantic surface sediments by means of carbonate grain size distribution, Journal of Sedimentary Research, 75 (3), 464-475.

Gaillardet, J., J. Viers, and B. Dupré (2003), 5.09- Trace elements in river waters, Treatise on Geochemistry, 5, 225-272. 
Ganssen, G.M., and D. Kroon (2000), The isotopic signature of planktonic foraminifera from NE Atlantic surface sediments; implication for the reconstruction of past oceanic conditions, Journal of the Geological Society, 157 (3), 693-699.

Gingele, F., and A. Dahmke (1994), Discrete barite particles and barium as tracers of paleoproductivity in South Atlantic sediment, Paleoceanography, 9 (1), 151-168.

Grobe H. (1987), A simple method for the determination of ice rafted debris in sediment cores, Polarforschung, 57 (3), 123-126.

Grobe H., and A. Mackensen (1992), Late Quaternary climatic cycles as recorded in sediments from the Antarctic continental margin, The Antarctic Paleonvironment: A perspective in global change, Antarctic research series, 56, 349-376.

Hall, I.R., I.N. McCave, N.J. Shackleton, G.P. Weedon, and S.E. Harris (2001), Intensified deep Pacific inflow and ventilation in Pleistocene glacial times, Nature, 412, 809-812.

Hall, J.M., and L.-H. Chan (2004), Ba/Ca in Neogloboquadrina pachyderma as an indicator of deglacial meltwater discharge into the western Arctic Ocean, Paleoceanography, 19, PA1017, doi:10.1029/2003PA000910.

Hays, J.D., J. Imbrie, and N.J. Shackleton (1976), Variations in the Earth's orbit: Pacemaker of the ice ages, Science, 194, 1121-1132.

Hayward, B.W., H. Neil, R. Carter, H.R. Grenfell, and J.J. Hayward (2002), Factors influencing the distribution patterns of Recent deep-sea benthic foraminifera, east of New Zealand, Southwest Pacific Ocean, Marine Micropaleontology, 46 (1-2), 139-176. 
Hayward, B.W., H.R. Grenfell, A.T. Sabaa, and H.L. Neil (2007), Factors influencing the distribution on Subantarctic deep-sea benthic foraminifera, Campbell and Bounty Plateaux, New Zealand, Marine Micropaleontology, 62 (3), 141-166.

Hayward B.W., G.H. Scott, M.P Crundwell, J.P. Kennett, L. Carter, H.L. Neil, A.T. Sabaa, K. Wilson, J.S. Rodger, G. Schaefer, H.R. Grenfell, and Q. Li (2008), The effect of submerged plateaux on Pleistocene gyral circulation and sea-surface temperatures in the Southwest Pacific, Global and Planetary Change, 63 (4), 309-316.

Hayward, B.W., A.T. Sabaa, A. Kolodziej, M.P. Crundwell, S. Steph, G.H. Scott, H.L. Neil, H.C. Bostock, L. Carter, and H.R. Grenfell (2012), Planktic foraminifera-based seasurafce temperature record in the Tasman Sea and history of the Subtropical Front around New Zealand, over the last one million years, Marine Micropaleontology, doi: 10.1016/j.marmicro.2011.10.003.

Head, R.N., D.W. Crawford, J.K. Egge, R.P. Harris, S. Kristiansen, D.J. Lesley, E. Marañón, D. Pond, and D.A. Purdie (1998), The hydrography and biology of a bloom of the coccolithophorid Emiliania huxleyi in the northern North Sea, Journal of Sea Research, 39 (3-4), 255-266.

Heath, R.A. (1985), A review of the physical oceanography of the seas around New Zealand, Journal of Marine and Freshwater Research, 19 (1), 79-124.

Hemleben, Ch., M. Spindler, and O.R. Anderson (1989), Modern Planktonic Foraminifera, Springer-Verlag, New York.

Herbert, T.D. (2003), Alkenone paleotemperature determinations, Treatise on Geochemistry, 6, 391-432. 
Herrmann, S., A.F. Weller, J. Henderiks, and H.R. Thierstein (2012), Global coccolith size variability in Holocene deep-sea sediments, Marine Micropaleontology, 82-83, 1-12.

Hesse, P.P. (1994), The record of continental dust from Australia in Tasman Sea sediments, Quaternary Science Reviews, 13, 257-272.

Heusser L.E., and G. Van de Geer (1994), Direct correlation of terrestrial and marine paleoclimatic records from four glacial-interglacial cycles -DSDP site 594 Southwest Pacific, Quaternary Science Reviews, 13, 273-282.

Hicks, D.M., and U. Shankar (2003), Sediment from New Zealand Rivers, NIWA chart, Miscellaneous Series No. 79.

Hill, K.L., S.R. Rintoul, R. Coleman, and K.R. Ridgway (2008), Wind-forced low frequency variability of the East Australian Current, Geophysical Research Letters, 35, L08602, doi:10.1029/2007GL032912.

Hill, K.L., S.R. Rintoul, K.R. Ridgway, and P.R. Oke (2011), Decadal changes in the South Pacific western boundary current system revealed in observations and ocean state estimates, Journal of Geophysical Research, 116, C01009, doi: 10.1029/2009JC005926.

Hillenbrand C.-D., G. Kuhn, and T. Frederichs (2009), Record of a Mid-Pleistocene depositional anomaly in West Antarctic continental margin sediments: An indicator for ice-sheet collapse? Quaternary Science Reviews, 28 (13-14), 1147-1159.

Hodell, D.A., C.D. Charles, and F.J. Sierro (2001), Late Pleistocene evolution of the ocean's carbonate system, Earth and Planetary Science Letters, 192 (2), 109-124. 
Holligan, P.M., A. Charalampopoulou, and R. Hutson (2010), Seasonal distributions of the coccolithophore, Emiliania huxleyi, and of particulate inorganic carbon in surface waters of the Scotia Sea, Journal of Marine Systems, 82 (4), 195-205.

Honjo, S. (1976), Coccoliths: Production, transportation and sedimentation, Marine Micropaleontology, 1, 65-79.

Huybers, P., and C. Wunsch (2005), Obliquity pacing of the late Pleistocene glacial terminations, Nature, 434, 491-494.

Huybers, P. (2006), Early Pleistocene Glacial Cycles and the Integrated Summer Insolation Forcing, Science, 313 (5786), 508-511.

Iida, T., K. Mizobata, and S.-I. Saitoh (2012), Interannual variability of coccolithophore Emiliania huxleyi blooms in response to changes in water column stability in the eastern Bering Sea, Continental Shelf Research, 34, 7-17.

Iglesias-Rodríguez, M.D., C.W. Brown, S.C. Doney, J. Kleypas, D. Kolber, Z. Kolber, P.K. Hayes, and P.G. Falkowski (2002), Representing key phytoplankton functional groups in ocean carbon cycle models: Coccolithophorids, Global Biogeochemical Cycles, 16 (4), 1100, doi:10.1029/2001GB001454.

Iglesias-Rodriguez, M.D., P.R. Halloran, R.E.M. Rickaby, I.R. Hall, E. Colmenero-Hidalgo, J.R. Gittins, D.R.H. Green, T. Tyrrell, S.J. Gibbs, P. von Dassow, E. Rehm, E.V. Armbrust, and K.P. Boessenkool (2008), Phytoplankton calcification in a high- $\mathrm{CO}_{2}$ world, Science, 320 (5874), 336-340.

Incarbona, A., B. Martrat, E. Di Stefano, J.O. Grimalt, N. Pelosi, B. Patti, and G. Tranchida (2010), Primary productivity variability on the Atlantic Iberian Margin over the last 
70,000 years: Evidence from coccolithophores and fossil organic compounds, Paleoceanography, 25, PA2218, doi:10.1029/2008PA001709.

Jacobs, S.S., C.F. Giulivi, and P.A. Mele (2002), Freshening of the Ross Sea during the late $20^{\text {th }}$ Century, Science, 297 (5580), 386-389.

James, M.R., and J.A. Hall (1998), Microzooplankton grazing in different water masses associated with the Subtropical Convergence round the South Island, New Zealand, Deep-Sea Research I, 45, 1689-1707.

Jickells, T.D., Z.S. An, K.K. Anderson, A.R. Baker, G. Bergametti, N. Brooks, J.J. Cao, P.W. Boyd, R.A. Duce, K.A. Hunter, H. Kawahata, N. Kubilay, J. laRoche, P.S. Liss, N. Mahowald, J.M. Prospero, A.J. Ridgwell, I. Tegen, and R. Torres (2005), Global iron connections between desert dust, ocean biogeochemistry, and climate, Science, 308 (5718), 67-71.

Jones, G.A., and P. Kaiteris (1983), A vacuum-gasometric technique for rapid and precise analysis of calcium carbonate in sediments and soils, Journal of Sedimentary Petrology, $53,655-660$.

Jouzel J., V. Masson-Delmotte, O. Cattani, G. Dreyfus, S. Falourd, G. Hoffmann, B. Minster, J. Nouet, J.M. Barnola, J. Chappellaz, H. Fischer, J.C. Gallet, S. Johnsen, M. Leuenberger, L. Loulergue, D. Luethi, H. Oerter, F. Parrenin, G. Raisbeck, D. Raynaud, A. Schilt, J. Schwander, E. Selmo, R. Souchez, R. Spahni, B. Stauffer, J.P. Steffensen, B. Stenni, T.F. Stocker, J.L. Tison, M. Werner, and E.W. Wolff (2007), Orbital and Millenial Antarctic climate variability over the past 800,000 years, Science, 317, 793796. 
Kanfoush S.L., D.A. Hodell, C.D. Charles, T.R. Janecek, and F.R. Rack (2002), Comparison of ice rafted debris and physical properties in ODP Site 1094 (South Atlantic) with the Vostok ice core over the last four climatic cycles, Paleogeography, Paleoclimatology, Paleoecology, 182 (3-4), 329-249.

Kawagata, S. (2001), Tasman Front shifts and associated paleoceanographic changes during the last 250,000 years: foraminiferal evidence from the Lord Howe Rise, Marine Micropaleontology, 41 (3-4), 167-191.

Khim, B-K, T. Sakamoto, and N. Harada (2012), Reconstruction of surface water conditions in the central region of the Okhotsk Sea during the last 180 kyrs, Deep Sea Research Part II: Topical Studies in Oceanography, 61-64, 63-72.

King, A.L., and W.R. Howard (2001), Seasonality of foraminiferal flux in sediment traps at Chatham Rise, SW Pacific: implications for paleotemperature estimates, Deep-Sea Research 1, 48, 1687-1708.

Kopp, R.E., F.J. Simons, J.X. Mitrovica, A.C. Maloof, and M. Oppenheimer (2009), Probabilistic assessment of sea level during the last interglacial stage, Nature, 462, 863867.

Langer, G., M. Geisen, K.-H. Baumann, J. Kläs, U. Riebesell, S. Thoms, and J.R. Young (2006), Species-specific responses of calcifying algae to changing seawater carbonate chemistry, Geochemistry, Geophysics, Geosystems, 7, Q09006, doi:10.1029/2005gc001227.

Le, J., and N.J. Shackleton (1992), Carbonate dissolution fluctuations in the western equatorial Pacific during the late Quaternary, Paleoceanography, 7, 21-42. 
Lea, D.W., P.A. Martin, D.K. Pak, and H.J. Spero (2002), Reconstructing a 350 ky history of sea level using planktonic $\mathrm{Mg} / \mathrm{Ca}$ and oxygen isotope records from a Cocos Ridge core, Quaternary Science Reviews, 21 (1-3), 283-293.

Legendre, L. (1990), The significance of microalgal blooms for fisheries and for the export of particulate organic carbon in oceans, Journal of Plankton Research, 12 (4), 681-699.

Lisiecki, L. E., and M. E. Raymo (2005), A Pliocene-Pleistocene stack of 57 globally distributed benthic $\mathrm{d}^{18} \mathrm{O}$ records, Paleoceanography, 20, 1-17.

Lohbeck, K.T, U. Riebesell, and T.B.H. Reusch (2012), Adaptive evolution of a key phytoplankton species to ocean acidification, Nature Geoscience, doi:10.1038/NGEO1441.

Loubere, P., P. Meyers, and A. Gary (1995), Benthic foraminiferal microhabitat selection, carbon isotope values, and association with larger animals: A test with Uvigerina peregrina, Journal of Foraminiferal Research, 25 (1), 83-95.

Lüer V., G. Cortese, H.L. Neil, C.J. Hollis, and H. Willems (2009), Radiolarian-based sea surface temperatures and paleoceanographic changes during the Late PleistoceneHolocene in the subantarctic southwest Pacific, Marine Micropaleontology, 70, 151165.

Mackie, D.S., P.W. Boyd, G.H. McTainsh, N.W. Tindale, T.K. Westberry, and K.A. Hunter (2008), Biogeochemistry of iron in Australian dust: From eolian uplift to marine uptake, Geochemistry, Geophysics, Geosystems, 9, Q03Q08, doi:10.1029/2007GC001813. 
Marr, J. P., 2009. Ecological, oceanographic and temperature controls on the incorporation of trace elements into Globigerina bulloides and Globoconella inflata in the Southwest Pacific Ocean (M.Sc. thesis). Victoria University of Wellington.

Marr, J.P., J.A. Baker, L. Carter, A.S.R. Allan, G.B. Dunbar, and H.C. Bostock (2011), Ecological and temperature controls on $\mathrm{Mg} / \mathrm{Ca}$ ratios of Globigerina bulloides from the southwest Pacific Ocean, Paleoceanography, 26, PA2209, doi:10.1029/2010PA002059.

Marr, J.P., L. Carter, H.C. Bostock, M. Handler, and A. Bolton (in prep.), Southwest Pacific Ocean response to a warming world: using $\mathrm{Mg} / \mathrm{Ca}, \mathrm{Mn} / \mathrm{Ca}, \mathrm{Zn} / \mathrm{Ca}$ and $\mathrm{Ba} / \mathrm{Ca}$ to track the surface ocean water masses over the last $25 \mathrm{ka}$.

Marra, M.J., E.G.C. Smith, J. Shulmeister, and R. Leschen, (2004), Late Quaternary climate change in the Awatere Valley, South Island, New Zealand using a sine model with a maximum likelihood envelope on fossil beetle data, Quaternary Science Reviews, 23, $1637-1650$.

Marra, M.J., B.V. Alloway, and R.M. Newnham (2006), Paleoenvironmental reconstruction of a well-preserved Stage 7 forest sequence catastrophically buried by basaltic eruptive deposits, northern New Zealand, Quaternary Science Reviews, 25, 2143-2161.

Martinez-Garcia, A., A. Rosell-Melé, S.L. Jaccard, W. Geibert, D.M. Sigman, and G.H. Haug (2011), Southern Ocean dust-climate coupling over the past four million years, Nature, $476,312-315$.

McGowan, H.A., G.H. McTainsh, P. Zawar-Reza, and A.P. Sturman (2000), Identifying regional dust transport pathways: Application of kinematic trajectory modelling to a trans-Tasman case, Earth Surface Processes and Landforms, 25, 633-647. 
McIntyre, A., and A.W.H. Bé (1967), Modern coccolithophoridae of the Atlantic ocean- I. Placoliths and cyrtoliths, Deep-Sea Research, 14, 561-597.

Mildenhall, D.C. (1995), Pleistocene palynology of the Petone and Seaview drillholes, Petone, Lower Hutt Valley, North Island, New Zealand, Journal of the Royal Society of New Zealand, 25 (2), 207-262.

McCave, I.N., and L. Carter (1997), Recent sedimentation beneath the Deep Western Boundary Current off northern New Zealand, Deep-Sea Research 1, 44 (7), 1203-1237.

McCave, I.N., L. Carter, and I.R. Hall (2008), Glacial-interglacial changes in water mass structure and flow in the SW Pacific Ocean, Quaternary Science Reviews, 27 (19-20), 1886-1908.

McCorkle, D.C., L.D. Keigwin, B.H. Corliss, and S.R. Emerson (1990), The influence of microhabitats on the carbon isotopic composition of deep-sea benthic foraminifera, Paleoceanography, 5, 161-185.

Mohtadi, M., S. Steinke, J. Groeneveld, H.G. Fink, T. Rixen, D. Hebbeln, B. Donner, and B. Herunadi (2009), Low-latitude control on seasonal and interannual changes in planktonic foraminiferal flux and shell geochemistry off south Java: A sediment trap study, Paleoceanography, 24, PA1201, doi:10.1029/2008PA001636.

Morel, F.M.M., A.J. Milligan, and M.A. Saito (2003), 6.05- Marine Bioinorganic Chemistry: The role of trace metals in the oceanic cycles of major nutrients, Treatise on Geochemistry, 6, 113-143.

Morris, M., B. Stanton, and H. Neil (2001), Subantarctic oceanography around New Zealand: preliminary results from an ongoing survey, New Zealand Journal of Marine and Freshwater Research, 35, 499-519. 
Mortyn, P.G., and C.D. Charles (2003), Planktonic foraminiferal depth habitat and $\delta^{18} \mathrm{O}$ calibrations: Plankton tow results from the Atlantic sector of the Southern Ocean, Paleoceanography, 18 (2), 1037.

Müller, M.N., L. Beaufort, O. Bernard, M.L. Pedrotti, A. Talec, and A. Sciandra (2012), Influence of $\mathrm{CO}_{2}$ and nitrogen limitation on the coccolith volume of Emiliania huxleyi (Haptophyta), Biogeosciences Discussion, 9, 4979-5010.

Multiza, S., A. Dürkoop, W. Hale, G. Wefer, and H.S. Niebler (1997), Planktonic foraminifera as recorders of past surface-water stratification, Geology, 25 (4), 335-338.

Murphy, R.J., M.H. Pinkerton, K.M. Richardson, J.M Bradford-Grieve, and P.W. Boyd (2001), Phytoplankton distributions around New Zealand derived from SeaWiFS remotely-sensed ocean colour data, New Zealand Journal of Marine and Freshwater Research, 35, 343-362.

Murray, J.W. (1991), Ecology and palaeoecology of benthic foraminifera, Longman Group UK Limited, Great Britain.

Neil, H.L., L. Carter, and M.Y. Morris (2004), Thermal isolation of Campbell Plateau, New Zealand, by the Antarctic Circumpolar Current over the past 130 kyr, Paleoceanography 19, PA4008, doi:10.1029/2003PA000975.

Nejstgaard, J.C., I. Gismervik, and P.T. Solberg (1997), Feeding and reproduction by Calanus finmarchicus, and microzooplankton grazing during mesocosm blooms of diatoms and the coccolithophore Emiliania huxleyi, Marine Ecology Progress Series, 147, 197-217. 
Nelson, C.S., C.H. Hendy, A.M. Cuthbertson, and G.R. Jarrett (1986), Late Quaternary carbonate and isotope stratigraphy, subantarctic site 594, southwest Pacific, Deep Sea Drilling Program Volume 90.

Nodder, S.D., and L.C. Northcote (2001), Episodic particulate fluxes at southern temperate mid-latitudes $\left(42-45^{\circ} \mathrm{S}\right)$ in the Subtropical Front region, east of New Zealand, Deep-Sea Research I, 48, 833-864.

Nodder, S.D., P.W. Boyd, S.M. Chiswell, M.H. Pinkerton, J.M. Bradford-Grieve, and M.N. Greig (2005), Temporal coupling between surface and deep-ocean biogeochemical processes in contrasting subtropical and subantarctic water masses, southwest Pacific Ocean, Journal of Geophysical Research, 112, C12017, doi:10.1029/2004JC002833.

Northcote, L.C., and H.L. Neil (2005), Seasonal variations in foraminiferal flux in the Southern Ocean, Campbell Plateau, New Zealand, Marine Micropaleontology, 56 (3-4), 122-137.

Okada, H., and P. Wells (1997), Late Quaternary nannofossil indicators of climate changes in two deep-sea cores associated with the Leeuwin Current off Western Australia, Palaeogeography, Palaeoclimatology, Palaeoecology, 131, 413-432.

Okazaki, Y., K. Takahashi, H. Asahi, K. Katsuki, J. Hori, H. Yasuda, Y. Sagawa, and H. Tokuyama (2005), Productivity changes in the Bering Sea during the late Quaternary, Deep Sea Research II: Topical Studies in Oceanography, 52 (16-18), 2150-2162.

Olson, M.B., and S.L. Strom (2002), Phytoplankton growth, microzooplankton herbivory and community structure in the southeast Bering Sea: insight into the formation and temporal persistence of an Emiliania huxleyi bloom, Deep-Sea Research II, 49 (26), 5969-5990. 
Orpin, A., L. Carter, A. Goh, E. Mackay, A. Pallentin, A.-L. Verdier, S. Chiswell, and P. Sutton (2008), New Zealand's diverse seafloor sediments, NIWA Chart, Miscellaneous Series No. 86.

Pahnke, K., R. Zahn, H. Elderfeild, and M. Schulz (2003), 340,000-Year Centennial-Scale Marine Record of Southern Hemisphere Climatic Oscillation, Science, 301, 948-952.

Paillard, D., L. Labeyrie, and P. Yiou (1996), Macintosh program performs time series analysis, Eos, Transactions, American Geophysical Union, 77, 379.

Pearce N.J.G, W.T. Perkins, J.A. Westgate, M.P. Gorton, S.E. Jackson, C.R. Neal, and S.P. Chenery (1997), A compilation of new and published major and trace element data for NIST SRM 610 and NIST SRM 612 glass reference materials, Geostandards Newsletter, 21, 115-144, doi:10.1111/j.1751-908X.1997.tb00538.x.

Pelejero C., E. Calvo, G.A. Logan, and P. De Deckker (2003), Marine Isotopic Stage 5e in the Southwest Pacific: Similarities with Antarctic and ENSO inferences, Geophysical Research Letters, 30 (23), 2185, doi:10.1029/2003GL018191.

Pelejero, C., E. Calvo, T.T. Barrows, G.A. Logan, and P. De Deckker (2006), South Tasman Sea alkenone palaeothermometry over the last four glacial/interglacial cycles, Marine Geology, 230 (1-2), 73-86.

Petit J.R., J. Jouzel, D. Raynaud, N.I. Barkov, J.M. Barnola, I. Basile, M. Bender, J. Chappellaz, M. Davisk, G. Delaygue, M. Delmotte, V.M. Kotlyakov, M. Legrand, V.Y. Lipenkov , C. Lorius, L. Pépin, C. Ritz, E. Saltzmank, and M. Stievenard (1999), Climate and atmospheric history of the past 420,000 years from the Vostok ice core, Antarctica, Nature, 399, 429-436. 
Pillans, B., G. Holgate, and M. McGlone (1988), Climate and Sea Level during Oxygen Isotope Stage 7b: On-Land Evidence from New Zealand, Quaternary Research, 29, 176-185.

Raiswell, R., L.G. Benning, M. Tranter, and S. Tulaczyk (2008), Bioavailable iron in the Southern Ocean: The significance of the iceberg conveyor belt, Geochemical Transations, 9 (7), doi:10.1186/1467-4866-9-7.

Raymo M.E., and Huybers, P. (2008), Unlocking the mysteries of the ice ages. Nature, 451, 284-285.

Redmayne, M., E. Smith, and M. Abramson (2012), A forecasting method to reduce estimation bias in self-reported cellphone data, Journal of Exposure Science and Environmental Epidemiology, in press, doi: 10.1038/jes.2012.70

Rhodes, L.L., B.M. Peake, A.L. Mackenzie, and S. Marwick (1995), Coccolithophores Gephyrocapsa oceanica and Emiliania huxleyi (Prymnesiophyceae =Haptophyceae) in New Zealand's coastal waters: characteristics of blooms and growth in laboratory culture, New Zealand Journal of Marine and Freshwater Research, 29, 345-357.

Ridgway, K.R., and J.R. Dunn (2003), Mesoscale structure of the mean East Australian Current System and its relationship with topography, Progress in Oceanography, 56 (2), 189-222.

Ridgway, K., and K. Hill (2009), The East Australian Current, in A Marine Climate Change Impacts and Adaption Report Card for Australia 2009, edited by E.S. Poloczanska, A.J. Hobday, and A.J. Richardson, NCCARF Publication 05/09, ISBN 978-1-921609-03-9.

Riegman, R., W. Stolte, A.A.M. Noordeloos, and D. Slezak (2000), Nutrient uptake and alkaline phosphatase (EC 3:1:3:1) activity of Emiliania huxleyi (prymnesiophyceae) 
during growth under N and P limitation in continuous cultures, Journal of Phycology, $36,87-96$.

Roemmich, D., and P.J.H. Sutton (1998), The mean and variability of ocean circulation past northern New Zealand: Determining the representativeness of hydrographic climatologies, Journal of Geophysical Research, 103 (C6), 13,041-13,054.

Roemmich, D., J. Gilson, R. Davies, P. Sutton, S. Wijffels, and S. Riser (2007), Decadal spinup of the South Pacific Subtropical Gyre, Journal of Physical Oceanography, 37, $162-173$.

Rohling, E.J., K. Grant, Ch. Hemleben, M. Siddall, B.A.A. Hoogakker, M. Bolshaw, and M. Kucera (2008), High rates of sea-level rise during the last interglacial period, Nature Geoscience, 1, 38-42.

Rohling, E.J., K. Grant, M. Bolshaw, A.P. Roberts, M. Siddall, Ch. Hemleben, and M. Kucera (2009), Antarctic temperature and global sea level closely coupled over the past five glacial cycles, Nature Geoscience, doi:10.1038/ngeo557.

Rost, B., and U. Riebesell (2004), Coccolithophore calcification and the biological pump: response to environmental changes, in Coccolithophores From Molecular Processes to Global Impact, edited by H.R. Thierstein and J.R. Young, pp. 99-127, Springer-Verlag Berlin Heidelberg, Germany.

Saavedra-Pellitero, M., J.A. Flores, F. Lamy, F.J. Sierro, and A. Cortina (2011), Coccolithophore estimates of paleotemperature and paleoproductivity changes in the southeast Pacific over the past 27 kyr, Paleoceanography, 26, PA1201, doi:10.1029/2009PA001824. 
Sadekov, A.Y., S.M. Eggins, G.P. Klinkhammer, and Y. Rosenthal (2010), Effects of seafloor and laboratory dissolution on the $\mathrm{Mg} / \mathrm{Ca}$ composition of Globigerinoides sacculifer and Orbulina universa tests -A laser ablation ICPMS microanalysis perspective, Earth and Planetary Science Letters, 292 (3-4), 312-324.

Saito, T., P.R. Thompson, and D. Breger (1981), Systematic index of Recent and Pleistocene planktonic foraminifera, University of Tokyo Press, Japan.

Schaefer, G., J.S. Rodger, B.W. Hayward, J.P. Kennett, A.T. Sabaa, and G.H. Scott (2005), Planktic foraminiferal and sea surface temperature record during the last $1 \mathrm{Myr}$ across the Subtropical Front, Southwest Pacific, Marine Micropaleontology, 54, 191-212.

Schiebel, R., J. Waniek, M. Bork, and C. Hemleben (2001), Planktic foraminiferal production stimulated by chlorophyll redistribution and entrainment of nutrients, Deep Sea Research Part 1: Oceanographic Research Papers, 48 (3), 721-740.

Schwager, C. (1866), Fossile Foraminiferen van Kar Nicobar, Reise der Österreichischen Fregatte Novara um die Erde in den Jahren 1857, 1858, 1859 unter den Befehlen des Commodore B. von Wüllerstorf-Urbair, Geologischer Theil, Geologische Beobachtung, 2, 187-268.

Schweizer, M., J. Pawlowski, T. Kouwenhoven, and B. van der Zwaan (2009), Molecular phylogeny of common cibicidids and related rotaliida (foraminifera) based on small subunit ${ }_{\mathrm{R}}$ DNA sequences, Journal of Foraminiferal Research, 39 (4), 300-315.

Schweizer, M., J. Pawlowski, I.A.P. Duijnstee, T.J. Kouwenhoven, and G.J. van der Zwaan (2005), Molecular phylogeny of the foraminiferal genus Uvigerina based on ribosomal DNA sequences, Marine Micropaleontology, 57 (3-4), 51-67.

SeaWiFS website- http://oceancolor.gsfc.nasa.gov/ 
Shackleton, N.J., and N.D. Opdyke (1973), Oxygen isotope and palaeomagnetic stratigraphy of Equatorial Pacific core V28-238: Oxygen isotope temperatures and ice volumes on a $10^{5}$ year and $10^{6}$ year scale, Quaternary Research, 3 (1), 39-55.

Shackleton N.J. (1987), Oxygen isotopes, ice volume and sea level, Quaternary Science Reviews, 6, 183-190.

Shulmeister, J., J.M. Soons, G.W. Berger, M. Harper, S. Holt, N. Moar, and J.A. Carter (1999), Environmental and sea-level changes on Banks Peninsula (Canterbury, New Zealand) through three glaciation-interglaciation cycles, Palaeogeography, Palaeoclimatology, Palaeoecology, 152, 101-127.

Siddall, M., J. Chappell, and E.-K. Potter (2007), 7. Eustatic sea level during past interglacials, in The Climate of Past Interglacials, Developments in Quaternary Sciences, 7, 75-92.

Sikes, E.L., T. O’Leary, S.D. Nodder, and J.K. Volkman (2005), Alkenone temperature record and biomarker flux at the subtropical front on the chatham rise, SW Pacific Ocean, Deep-Sea Research 1, 52, 721-748.

Sikes, E.L., W.R. Howard, C.R. Samson, T.S. Mahan, L.G. Robertson, and J.K. Volkman (2009), Southern Ocean seasonal temperature and Subtropical Front movement on the South Tasman Rise in the late Quaternary, Paleoceanography, 24, PA2201, doi:10.1029/2008PA001659.

Smith Jr, K.L., B.H. Robinson, J.J. Helly, R.S. Kaufmann, H.A. Ruhl, T.J. Shaw, B.S. Twining, and M. Vernet (2007), Free-drifting icebergs: Hot spots of chemical and biological enrichment in the Weddell Sea, Science, 317, 478-482. 
Smyth, T.J., T. Tyrrell, and B. Tarrant (2004), Time series of coccolithophore activity in the Barents Sea, from twenty years of satellite imagery, Geophysical Research Letters, 31, L11302, doi:10.1029/2004GL019735.

Soons, J.M., N.T. Moar, J. Shulmeister, H.D. Wilson, and J.A. Carter (2002), Quaternary vegetation and climate changes on Banks Peninsula, South Island, New Zealand, Global and Planetary Change, 33, 301-314.

Stanton, B.R. (1973), Hydrological investigations around northern New Zealand, New Zealand Journal of Marine and Freshwater Research, 7 (1 \& 2), 85-110.

Stanton, B.R., P.J.H. Sutton, and S.M. Chiswell (1997), The East Auckland Current, 1994-95, New Zealand Journal of Marine and Freshwater Research, 31, 537-549.

Stanton, B.R. (2002), Antarctic Intermediate Water variability in the northern New Zealand region, New Zealand Journal of Marine and Freshwater Research, 36, 645-654.

Stanton, .B.R., and M.Y. Morris (2004), Direct velocity measurements in the Subantarctic Front and over Campbell Plateau, southeast of New Zealand, Journal of Geophysical Research, 19, C01028, doi:10.1029/2002JC001339.

Sunda, W.G., and S.A. Huntsman (1998), Interactive effects of external manganese, the toxic trace metals copper and zinc, and light in controlling cellular manganese and growth in a coastal diatom, Limnology and Oceanography, 43 (7), 1467-1475.

Sutton, P.J.H., and D. Roemmich (2001), Ocean temperature climate off north-east New Zealand, New Zealand Journal of Marine and Freshwater Research, 35, 553-565. 
Sutton, P.J.H., M. Bowen, and D. Roemmich (2005), Decadal temperature changes in the Tasman Sea, New Zealand, New Zealand Journal of Marine and Freshwater Research, $39(6), 1321-1329$.

Tagliabue, A., L. Bopp, J.-C. Dutay, A.R. Bowie, F. Chever, P. Jean-Baptiste, E. Bucciarelli, D. Lannuzel, T. Remenyi, G. Sarthou, O. Aumont, M. Gehlen, and C. Jeandel (2010), Hydrothermal contribution to the oceanic dissolved iron inventory, Nature Geoscience, $3,252-256$.

Teitler, L., D.A. Warnke, K.A. Venz, D.A. Hodell, S. Becquey, R. Gersonde, and W. Teitler (2010), Determination of Antarctic Ice Sheet stability over the last $\sim 500$ ka through a study of iceberg-rafted debris, Paleoceanography, 25, PA1202, doi:10.1029/2008PA001691

Thiede, J., S. Nees, H. Schulz, and P. De Deckker (1997), Oceanic surface conditions recorded on the sea floor of the Southwest Pacific Ocean through the distribution of foraminifers and biogenic silica, Palaeogeography, Palaeoclimatology, Palaeoecolgy, 131 (3-4), 207-239.

Thierstein, H.R., K.R. Geitzenauer, B. Molfino, and N.J. Shackleton (1977), Global synchroneity of late Quaternary coccolith datum levels, validation by oxygen isotopes, Geology, 5 (7), 400-404.

Thompson, P.R., A.W.H. Bé, J-C Duplessy, and N.J. Shackleton (1979), Disappearance of pink-pigmented Globigerinoides ruber at 120,000 yr BP in the Indian and Pacific Oceans, Nature, 280, 554-558.

Toggweiler J.R., and J. Russell (2008), Ocean circulation in a warming climate, Nature, 451, 286-288. 
Trimborn S., G. Langer, and B. Rost (2007), Effect of varying calcium concentrations and light intensities on calcification and photosynthesis in Emiliania huxleyi. Limnology and Oceanography, 52 (5), 2285-2293.

Tyrrell, T., P.M. Holligan, and C.D. Mobley (1999), Optical impacts of oceanic coccolithophore blooms, Journal of Geophysical Research- Oceans, 104, 3223-3241.

Tyrrell, T., and A. Merico (2004), Emiliania huxleyi: bloom observations and the conditions that induce them, in Coccolihtophores From Molecular Processes to Global Impact, edited by H.R. Thierstein and J.R. Young, pp. 75-99, Springer-Verlag Berlin Heidelberg, Germany.

Weldeab, S., D.W. Lea, R.R. Schneider, and N. Anderson (2007), 155,000 years of West African monsoon and ocean thermal evolution, Science, 319 (5829), 1303-1307

Zahn, R., K. Winn, and M. Sarnthein (1986), Benthic foraminiferal $\delta^{13} \mathrm{C}$ and accumulation rates of organic carbon: Uvigerina peregrina group and Cibicidoides wuellerstorfi, Paleoceanography, 1 (1), 27-42.

Ziveri, P., K.-H., Baumann, B. Böckel, J. Bollman, and J. Young (2004), Biogeography of selected Holocene coccoliths in the Atlantic Ocean, in Coccolithophores From Molecular Processes to Global Impact, edited by H.R. Thierstein and J.R. Young, pp. 403-429, Springer-Verlag Berlin Heidelberg, Germany.

Zondervan, I (2007), The effects of light, macronutrients, trace metals and $\mathrm{CO}_{2}$ on the production of calcium carbonate and organic carbon in coccolithophores $-\mathrm{A}$ review, Deep-Sea Research II, 54, 521-537. 
